\title{
A Systematic Method for Measuring Gentrification Using Building Permits Data: A Washington D.C Case Study
}

\author{
Andey Fomil \\ West Virginia University, anfomil@mix.wvu.edu
}

Follow this and additional works at: https://researchrepository.wvu.edu/etd

Part of the Demography, Population, and Ecology Commons, Geographic Information Sciences Commons, Human Geography Commons, Quantitative, Qualitative, Comparative, and Historical Methodologies Commons, Spatial Science Commons, and the Urban Studies and Planning Commons

\section{Recommended Citation}

Fomil, Andey, "A Systematic Method for Measuring Gentrification Using Building Permits Data: A Washington D.C Case Study" (2021). Graduate Theses, Dissertations, and Problem Reports. 8142. https://researchrepository.wvu.edu/etd/8142

This Thesis is protected by copyright and/or related rights. It has been brought to you by the The Research Repository @ WVU with permission from the rights-holder(s). You are free to use this Thesis in any way that is permitted by the copyright and related rights legislation that applies to your use. For other uses you must obtain permission from the rights-holder(s) directly, unless additional rights are indicated by a Creative Commons license in the record and/ or on the work itself. This Thesis has been accepted for inclusion in WVU Graduate Theses, Dissertations, and Problem Reports collection by an authorized administrator of The Research Repository @ WVU. For more information, please contact researchrepository@mail.wvu.edu. 


\section{A Systematic Method for Measuring Gentrification Using Building Permits Data: A Washington D.C Case Study}

Andey Fomil

Follow this and additional works at: https://researchrepository.wvu.edu/etd

Part of the Demography, Population, and Ecology Commons, Geographic Information Sciences

Commons, Human Geography Commons, Quantitative, Qualitative, Comparative, and Historical Methodologies Commons, Spatial Science Commons, and the Urban Studies and Planning Commons 


\title{
A Systematic Method for Measuring Gentrification Using Building Permits Data: A Washington D.C Case Study
}

\author{
Andrey "Andrew" Fomil
}

Thesis submitted to the Eberly College of Arts and Sciences at West

Virginia University

In partial fulfillment of the requirements for the degree of Master of Arts in Geography

Jamison Conley, Ph.D., Chair

Gregory EImes, Ph.D.

Aaron Maxwell, Ph.D.

Department of Geography

Morgantown, West Virginia

2021

Keywords: GIS, Human Geography, Spatial Analysis, Demographics, Urban Studies

Copyright 2021 Andrey Fomil 


\title{
ABSTRACT \\ A Systematic Method for Measuring Gentrification Using Building Permits Data: A Washington D.C Case Study
}

\author{
Andrey Fomil
}

Gentrification can significantly alter the socioeconomic, demographic, and commercial aspects of a city. It is a complex process that transforms the characteristics of entire neighborhoods, modifying not only the observable physical aspects, but also the community structure.

Traditional quantitative gentrification measurement approaches assess the process through analysis of Census demographic indicators coupled with field visit analysis of the physical built environment. This study proposes a new gentrification measuring approach that combines traditional Census indicators with a new indicator in the form of City Building Permits. Two GIS spatial analysis techniques are utilized to evaluate the effectiveness and accuracy of the proposed approach in assessing the distribution and intensity of fine scale spatial gentrification. The results of the spatial analyses are validated through an assessment of local media sources reporting on gentrification in the study area. 


\section{Table of Contents}

1. Introduction .......................................................................................................1

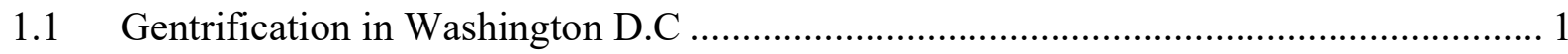

1.2 Assessing and Quantitatively Analyzing Gentrification ......................................... 2

1.3 Core Objective Research Question ......................................................................... 3

2. Literature Review ..........................................................................................4

2.1 Historical Origins: Defining Gentrification ......................................................... 4

2.2 Evolving Definitions and Conflicting Perceptions.................................................. 4

2.3 Geographic and Spatial Aspects of Gentrification .................................................. 5

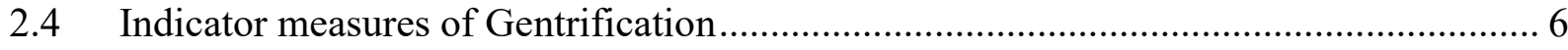

2.5 Application of GIS in measuring Gentrification ................................................ 12

3. Case Study ...............................................................................................................13

4. Research Questions .................................................................................................15

5. Analysis ...................................................................................................................16

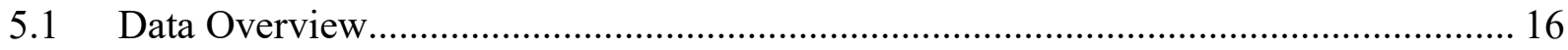

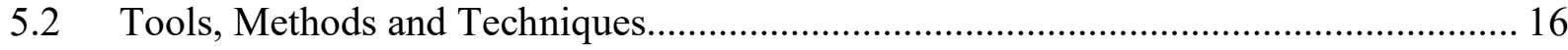

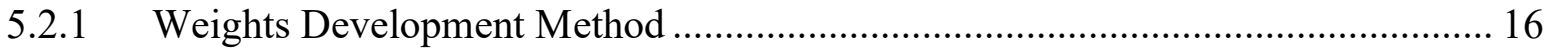

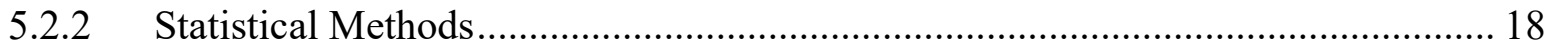

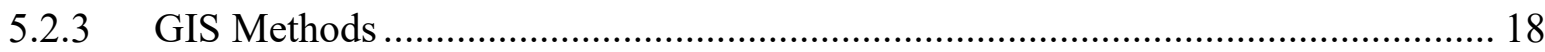

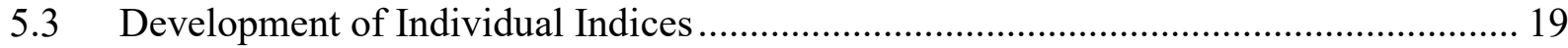

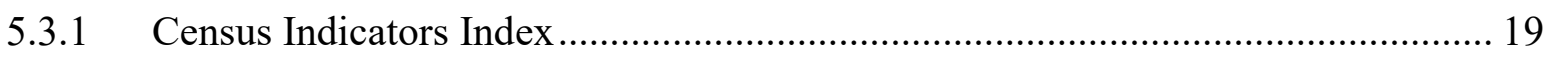

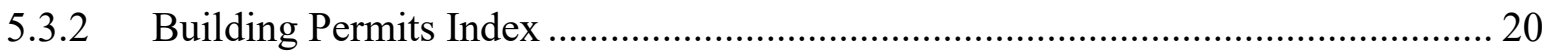

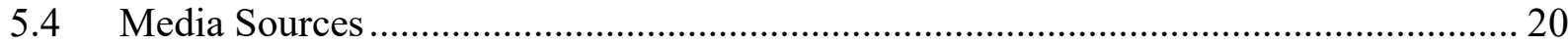

5.5 Analytical Process Model and Final Composite Index ............................................ 21

6. Results.......................................................................................................................26

6.1 Census Indicators Change Analysis and Index ................................................. 26

6.1.1 Census Indicators Change Analysis........................................................... 26

6.1.2 6.1.2 Census Indicators Index .................................................................... 26

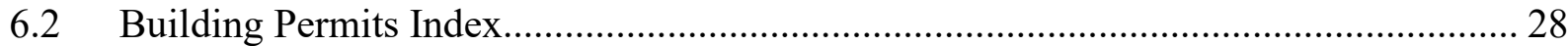




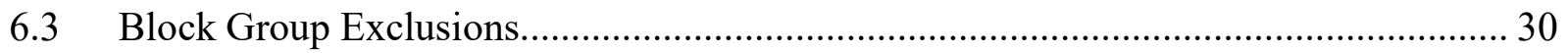

6.4 Correlation and Spatial Analysis Results ................................................................... 30

6.4.1 Composite Index and GWR ……………………........................................... 30

6.4.1 Bivariate Moran's I ........................................................................................... 31

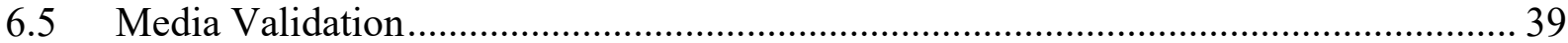

7. Discussions and Conclusion ..............................................................................43

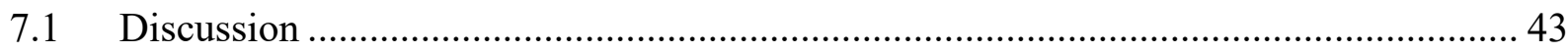

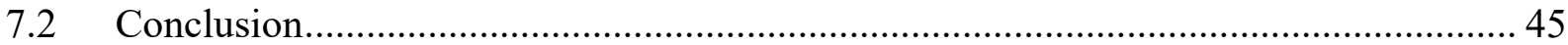

8. Appendix A - Tables and Figures............................................................46

9. Appendix B - Media Sources........................................................................60

10. Appendix C - References.........................................................................66

\section{List of Figures}

Figure 1pt1: AHP Model "A Novel Gentrification Index (Census Indicators and Building

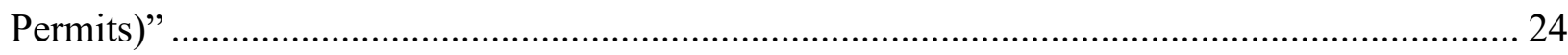

Figure 1pt2: AHP Model "A Novel Gentrification Index (Census Indicators and Building

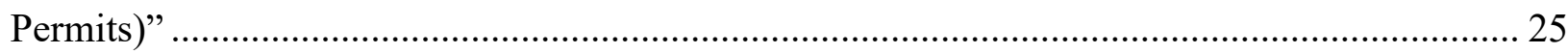

Figure 2: Final Standardized Composite Index (Census Indicators and Building Permits........... 33

Figure 3: GWR Output with 10 Nearest Neighbor Parameter ..................................................... 34

Figure 4: GWR Output with 20 Nearest Neighbor Parameter................................................... 35

Figure 5: GWR Output with 30 Nearest Neighbor Parameter ..................................................... 36

Figure 6: GeoDa Bivariate Moran's I Significance Output (Left to Right: 10NN, 20NN, 30NN)

Figure 7: GeoDa Bivariate Moran's I "HotSpots"/"ColdSpots" Output (Left to Right: 10NN, $20 \mathrm{NN}, 30 \mathrm{NN}$ ).

Figure 9: Media Reported Gentrification Associated to Neighborhood Clusters Overlay with GWR 30NN Gentrifying Block Groups 


\section{List of Tables}

Table 1: Comparison of a Sample of Studies with New Approaches to Measuring Gentrification 7

Table 2: Census Demographics for Washington DC 2010-2019................................................ 14

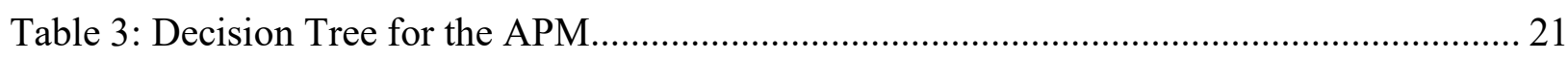

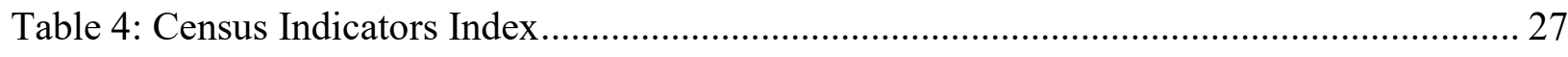

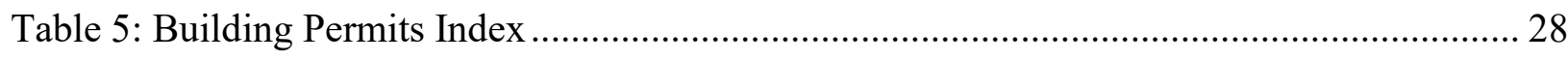

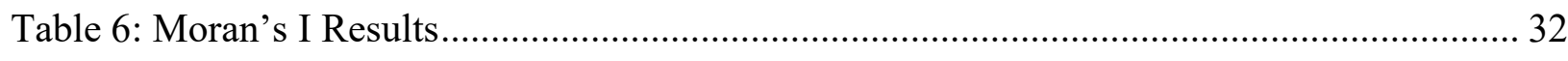

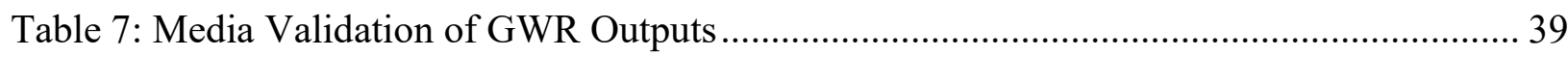

Table 8: Media Validation of Bivariate Moran's I Outputs........................................................... 40 
"...Looka here people, listen to me,

Don't try to find no home in Washington, D.C.

Lord, it's a bourgeois town, it's a bourgeois town."

(Huddie "Leadbelly" Ledbetter, U.S. Blues Musician. "Bourgeois Blues", 1938).

\section{Introduction}

The shortage of affordable housing is one of the most significant and one of the most complex issues facing modern cities. Many urban centers are grappling with affordable housing scarcities, attempting to balance speculative investment against equitable development and capital public housing proposals (Reed, 2012; U.S Dept of Housing and Urban Development,2018; Zonta, 2020). To facilitate continued economic growth, and to attract and retain affluent demographic groups, city governments aim to create unique territorial combinations of tax breaks, building code regulations, capital improvement projects, and zoning laws (U.S Dept of Housing and Urban Development, 2018). The drive to attract and retain wealthier demographic groups can come at the expense of less prosperous local dwellers and may lead to the destruction of longstanding cultural locales and communities, create accessibility barriers for less affluent middle and lower income demographics, or sometimes result in native dwellers being priced out of their own neighborhoods (Tach, Pendal, and Derain, 2014; Zonta, 2020).

The scale and magnitude of uncontrolled urban transformation depends on a city's ability to accurately monitor, control, document, and report change. The capacity to transparently report and inform residents on current and future developments is critical to ensuring equitability for local lower and middle-income earners and can help mobilize agile community responses (U.S Dept of Housing and Urban Development, 2018). A city's ability to ensure compliance with development regulations must be thorough and across multiple indicators, maintaining housing accessibility and affordability, but without intimidating or deflecting potential investors (U.S Dept of Housing and Urban Development, 2018). Successfully managed growth allows a city to support revitalization and new development while still protecting the native established residents, safeguarding local culture and history, and maintaining a fair level of accessibility for various levels of income demographics.

\subsection{Gentrification in Washington D.C}

Huddie Ledbetter's 1938 song Bourgeois Blues continues to ring true for many parts of today's Washington D.C. Transcending the test of time, the ballad still accurately depicts the "bourgeois" character of many neighborhoods in the modern District of Columbia. Over the past decade, 2010-2020, the city has seen a dramatic increase in redevelopment, revitalization, real estate speculation, and especially gentrification. Rejuvenation of the built environment increases the city's livability appeal, increases the tax base, reshapes entire neighborhoods, and 
complements the surging gentrification. A continuous influx of affluent residents continues to cultivate the District's image as a "bourgeois" town, creating shortages of affordable housing and displacing native residents (Reed, 2012; Plerhoples et al, 2015; Wogan, 2015).

Gentrification transforms the characteristics of entire neighborhoods, modifying not only the observable physical aspects, but also the traditional community structure. It can significantly alter the socioeconomic, demographic, and commercial aspects of a neighborhood. In the last 20 years, many large urban centers across the country have experienced massive redevelopment, commercialization, and gentrification (Maciag, 2015). The city of Washington D.C has been called a gentrification "hotbed" by numerous urban development scholars and institutions (Wyly and Hammel, 1999; Nesbitt, 2005; Kennedy and Leonard, 2011, Brookings Institute, 2015; Maciag, 2015; Green et al., 2017; U.S Dept of Housing and Urban Development, 2018; Shinault and Seltzer, 2019). The prevalence and magnitude of urban change in the District has garnered considerable local media coverage, as well as extensive discussions in local forums and blogs. A 2013 article in the Washington City Paper asked if there are any neighborhoods left in the District that are not gentrifying? (Wiener, 2013).

\subsection{Assessing and Quantitatively Analyzing Gentrification}

Assessing gentrification is a complex, multidisciplinary process, and a clear consensus on a systemic quantitative methodological approach to measuring gentrification and evaluating its intensity (or magnitude) is still being developed. Current research approaches to measuring gentrification employs a mix of multi-disciplinary analysis techniques. A more prevalent traditional approach is to combine statistical analysis of census data with a qualitative research method in the form of local resident interviews, photographic field surveys, and ethnographic or sociologic research.

With increased innovation in computer processing power, and with the growing accessibility to big open data, modern assessments of gentrification have benefited from the integration of advanced computational methodologies. Current forward-leaning studies have leveraged big open source data in the forms of social media applications such as Yelp and Twitter (Glaeser et al., 2018; Aike et al., 2019), while other tech savvy research has looked to employ Machine Learning (ML) in conjunction with Google Streetview images to help detect and identify built environmental change associated with gentrification (Ilic et al., 2019), or to create advanced demographic indicator models that use ML decision trees and random forests to detect ongoing gentrification and to forecast future growth (Reades et al., 2019). Geographic Information Systems (GIS) continue to be critical instruments in gentrification analysis. GIS is usually employed to produce powerful visualizations or as advanced spatial analytics tools, with significant study specific variations in the style, consistency, and degree of GIS application and utilization (Nesbitt, 2005; Papachristos et al., 2011; Fouch, 2011; Welch, 2013; Maantay \& Maroko, 2018; Glaeser et al., 2018; Aike et al., 2019; Ilic et al., 2019; Reades et al., 2019). 


\subsection{Core Objective Research Question}

This study proposes a consistent repeatable method for measuring gentrification and gentrification intensity on a large scale. The main objective of this study is to determine:

Does Building Permit data provide an accurate fine spatial resolution assessment of the distribution and intensity of gentrification in a large urban center?

To detect large scale spatial distributions of gentrification, and to measure their intensity, this study will aim to fuse GIS analysis of big data (Building Permits) with classic/traditional Census gentrification indicator approaches established by previous studies. Although previous studies have attempted to leverage building conditions and real estate data (Heidkamp and Lucas, 2006; Chapple, 2009; Levy, 2009; Aike, 2018), a focused analysis of Building Permits over an extended temporal period has rarely been attempted. To provide an independent confirmation of this new method, and to further assess its accuracy, an analysis of local media coverage of gentrification will be performed. A case study of Washington, D.C. will be used to evaluate the effectiveness of the new method, analyze if it can serve as a valuable addition to already existing measures, and to ascertain its repeatability and replication in other study areas.

To gain a greater understanding of gentrification this study will present and discuss gentrification's theoretical foundations in the literature review. The literature review will evaluate how gentrification was first recognized historically and defined within academic institutions, discuss how it is identified and detected, and review how GIS and other analysis techniques are employed to measure the spatial and geographic aspects of the phenomena.

Following the literature review, the case study section presents the study area, the city of Washington D.C. and concisely examines various conditions indicative of gentrification. The case study section includes an overview of the socioeconomic, demographic, and community changes occurring within the study area over the past decade, and briefly address why Washington D.C is an appropriate testing site for the new method.

The analysis and results sections that will follow, will focus on research approaches, data selection, and analysis methods and techniques. Data acquisition methods, data exploration, data processing, and selected GIS analysis techniques are covered in the analysis section, while the results section summarizes the results of the analysis, covering statistical and cartographic outputs, and presenting the results through figures.

The last two sections are the discussion and conclusion. The discussion section reviews analysis results, explores new insights gained, and assesses the accuracy of the new method through comparison with local media coverage. The conclusion reviews the success and utility of the new method and recommend enhancements and possible improvements for future work. 


\section{Literature Review}

\subsection{Historical Origins: Defining Gentrification}

Previously, the way gentrification has been defined has varied across studies. Some studies have attempted to create their own definitions or interpretations, while others have referenced historical literature, but most are based on the foundations established by Ruth Glass (Glass, 1961). Rowland Atkinson (2000) describes how sociologist Ruth Glass coined the term gentrification to describe the redevelopment process she observed in 1960's London. Glass studied and recorded how working class groups were displaced from their neighborhoods and communities by "The Gentry" (wealthier middle and upper classes), a process that changed the built conditions and community characteristics of these neighborhoods as they became "Gentrified".

In the late $20^{\text {th }}$ and early $21^{\text {st }}$ centuries increased urban revitalization stimulated many inner-city neighborhoods to experience redevelopment and gentrification (Hartog, 1999; Krausmann et al., 2009). This increased and considerably rapid urban change has heightened interest in gentrification research within various academic disciplines. Geographers have taken notice of the spatial phenomena and have been keen to study it, with some of the discipline's most prominent scholars, such as David Ley and Neil Smith, conducting gentrification research (Schaffer and Smith, 1986; Ley, 2003; Smith and Williams, 2007; Ley and Teo, 2013).

Richard Schaffer and Neil Smith conducted extensive work on gentrification in Harlem in the 1980's. Schaffer and Smith defined gentrification as "the movement of middle class families into urban areas causing property values to increase and having the secondary effect of driving out poorer families" (Schaffer and Smith, 347).

Maureen Kennedy and Paul Leonard of the Brookings Institute mirrored Schaffer and Smith's definition, "we define gentrification as the process by which higher income households displace lower income residents of a neighborhood, changing the essential character and flavor of that neighborhood" (Kennedy and Leonard, 2001). Scholars define gentrification as a process of physical and social neighborhood metamorphosis. However, gentrification is not instantaneous, and is often signaled by or associated with specific demographic, socioeconomics, and environmental indicators.

\subsection{Evolving Definitions and Conflicting Perceptions}

The conceptualization of gentrification as a process emerged on the heels of the urban renewal and slum clearance programs implemented in the 1950s and 1960s. In the U.K. early gentrification systematically reorganized the lower income working class neighborhoods, such as east London, into more desirable higher income communities that improve the overall image of 
the city, further attracting more affluent residents (Schaffer and Smith, 1986). Glass (1961) observed some of these reorganizations and neighborhood revitalizations, documenting her observations, and formalizing her personal accounts into the first pioneering example of gentrification research.

While most scholars perceive gentrification as a phenomenon that has negative social and community effects, there have been contrary opinions. Some scholars have perceived gentrification as a constructive and progressive force, focusing on its positive side effects and outcomes, and circumventing or downplaying some of the more drastic negative effects. Sternlieb and Hughes hailed gentrification as a triumph that can potentially bring higher property taxes and enhance the economic vigor and vitality of a city (Sternlieb and Hughes, 1979). Schaffer and Smith readily agreed with this assertion and expanded upon it by claiming that gentrification is lauded as the major hope for reversing economic and social decline dominating many inner-city neighborhoods (Schaffer and Smith, 1986).

Many contemporary gentrification studies have focused on evaluating the negative social fallouts of the process or how to responsibly manage gentrification. There have been a myriad of studies analyzing and investigating the adverse effects of gentrification such as displacement and community loss (Axel-Lute, 2002; Rose, 2002; Doan and Higgins, 2011; Bates, 2012; Zuk et al., 2015; Green et al., 2017; Shinault and Seltzer, 2019; Christafore \& Leguizamon, 2019).

The goal of this study is not to evaluate the effects of gentrification or to redefine the phenomena. Instead this study aims to provide an improvement or an enhancement to methods of measurement, so that future gentrification scholars can leverage the methodologies and analytical processes presented in this study to conduct large scale spatial resolution gentrification analysis or to complement qualitative neighborhood focused research.

\subsection{Geographic and Spatial Aspects of Gentrification}

Rosenthal and Brueckner (2009) established gentrification as a one the of deep-seated forces that will substantially alter locational patterns of residential land-use within most U.S cities. They theorized that the nature of gentrification is cyclical, and operates in close conjunction with political climates, economic incentives, urban revitalization drives, and dwelling ages. As the inner city becomes increasingly redeveloped, it also becomes a more desirable living space for higher income earners accustomed to accessibility, newer housing, and modern amenities (Rosenthal and Brueckner, 2009). Proximity to the Central Business District (CBD), adjacency to cultural and historical locations, topographical amenities, and a renovated built-environment are the main factors attracting higher income residents to gentrifying areas (Rosenthal and Brueckner, 2009).

The spatial distributions of gentrified and gentrifying neighborhoods, and their tendency to emerge from within "poorer" urban areas are explored by Elvin Wyly and Daniel Hammel in 
two different publications. In Islands of Decay in Seas of Renewal (1999), the authors delve into how gentrification changes a neighborhood both socially and physically, while placing emphasis on the heterogeneous nature of the process. In "Modeling the Context and Contingency of Gentrification", Wyly and Hammel (1998) explore the spatial aspects of gentrification and its effects on the socioeconomic composition of neighborhoods and communities. They observe similar patterns of change in different cities, leading them to conclude that often times modern gentrification signifies a new and distinct dimension of urban socio-spatial structure that displays similar characteristics and effects across different urban centers, with slight differences depending on context and geography, and local demographics.

\subsection{Indicator measures of Gentrification}

Gentrification studies have traditionally focused on analyzing changes in demographic variables as a means for measuring the process. At the core of most gentrification studies is a change assessment of gentrification associated Census variables such as race, education, and income (see Table 1 for details).

Assessing gentrification through Census data is an essential and valuable measuring approach. Nevertheless, gentrification studies have been intent on identifying additional indicators beyond the Census (or expanding the Census variables beyond demographics, with the inclusion of Census-based housing conditions). Scholars have become creative in their quests to find new variables, and new measuring methods. As research into gentrification progressed and intensified, studies looked to reinforce Census data with additional environmental dimensions (Braswell, 2018; Maantay and Maroko, 2018), commercial indicators (Glaeser et al., 2018), crime statistics (O'Sullivan, 2004; Papachristos et al., 2011), school data (Mann \& Rogers, 2020), and with qualitative neighborhood focused survey methodologies (Green et al., 2017; Shinault \& Seltzer, 2019). Modern gentrification research is eager to identify new indicator variables or explore supplementary ways to measure the process, with contemporary gentrification studies intent on complementing Census variables with non-Census-based indicators. Table 1 below provides an overview of more modern gentrification literature that focuses on introducing non-traditional indicators for gentrification measurement. 
Table 1: Comparison of a Sample of Studies with New Approaches to Measuring Gentrification

\begin{tabular}{|c|c|c|c|c|c|c|c|}
\hline Study & $\begin{array}{c}\text { Definition of } \\
\text { gentrifying/gentrified }\end{array}$ & Unit/Scale of analysis/model & $\begin{array}{l}\text { Stages/Index/Measure } \\
\text { of Gentrification }\end{array}$ & Indicators & Methods & $\begin{array}{l}\text { Accounts for } \\
\text { Unique local } \\
\text { characteristics? }\end{array}$ & Limitations \\
\hline $\begin{array}{l}\text { O’Sullivan } \\
(2005)\end{array}$ & $\begin{array}{l}\text { Census variables and } \\
\text { reduction in crime. }\end{array}$ & Census Tract. & $\begin{array}{l}\text { Post gentrification, and } \\
\text { gentrification in progress. }\end{array}$ & $\begin{array}{l}\text { U.S census data, } \\
\text { housing data, } \\
\text { crime. }\end{array}$ & $\begin{array}{l}\text { Econometric model for competition of } \\
\text { inner-city land and to changes in } \\
\text { indicators. }\end{array}$ & Yes. & $\begin{array}{l}\text { Scale, no } \\
\text { attempt to use } \\
\text { GIS to spatially } \\
\text { analyze or } \\
\text { visualize. }\end{array}$ \\
\hline $\begin{array}{l}\text { Nesbitt } \\
(2005)\end{array}$ & $\begin{array}{l}\text { Based on previous } \\
\text { literature, personal } \\
\text { study area knowledge, } \\
\text { and local characteristics }\end{array}$ & Census Tract. & $\begin{array}{l}\text { Ongoing and future } \\
\text { gentrification. }\end{array}$ & $\begin{array}{l}\text { U.S census data, } \\
\text { housing data, } \\
\text { amenities. }\end{array}$ & $\begin{array}{l}\text { Used a weighted index to detect ongoing } \\
\text { and future gentrification. }\end{array}$ & Yes. & $\begin{array}{l}\text { Scale, sample } \\
\text { size. }\end{array}$ \\
\hline $\begin{array}{l}\text { Gambrill } \\
(2007)\end{array}$ & $\begin{array}{l}\text { Changes in } \\
\text { demographics and real } \\
\text { estate prices. }\end{array}$ & $\begin{array}{l}\text { Zip Codes, neighborhoods, } \\
\text { census Block Groups, and } \\
\text { individual locations. }\end{array}$ & $\begin{array}{l}\text { Ongoing and new } \\
\text { gentrification. }\end{array}$ & $\begin{array}{l}\text { U.S census data, } \\
\text { and Private sector } \\
\text { real estate home } \\
\text { price data. }\end{array}$ & $\begin{array}{l}\text { GIS used for modeling and to correlate } \\
\text { property price changes with socio- } \\
\text { demographic changes. }\end{array}$ & $\begin{array}{l}\text { Yes, but the study } \\
\text { admits that } \\
\text { variables could be } \\
\text { optimized with } \\
\text { local community } \\
\text { dynamics. }\end{array}$ & $\begin{array}{l}\text { Inconsistent } \\
\text { Scale, choice } \\
\text { of } \\
\text { methodology. }\end{array}$ \\
\hline $\begin{array}{l}\text { Heidkamp } \\
\text { and Lucas } \\
(2006)\end{array}$ & $\begin{array}{l}\text { Upgrades to residential } \\
\text { buildings, new } \\
\text { businesses, income } \\
\text { comparison }\end{array}$ & Block Groups. & $\begin{array}{l}\text { Study analyzes ongoing } \\
\text { gentrification or } \\
\text { gentrification in progress. }\end{array}$ & $\begin{array}{l}\text { U.S census and } \\
\text { field observations } \\
\text { of physical } \\
\text { environment. }\end{array}$ & $\begin{array}{l}\text { Census Data analysis. Field surveys } \\
\text { observations helped determined a } \\
\text { categorical classification for } \\
\text { gentrification based on level of physical } \\
\text { and environmental upgrading. }\end{array}$ & $\begin{array}{l}\text { Yes. Field } \\
\text { Research was } \\
\text { utilized to } \\
\text { delineate unique } \\
\text { neighborhood } \\
\text { characteristics. } \\
\end{array}$ & $\begin{array}{l}\text { Scale, sample } \\
\text { size. }\end{array}$ \\
\hline Levy (2009) & $\begin{array}{l}\text { Increase in housing } \\
\text { market value, property } \\
\text { tax changes. }\end{array}$ & $\begin{array}{l}\text { One Neighborhood and a sample } \\
\text { of residential properties in this } \\
\text { neighborhood. }\end{array}$ & Gentrification in progress. & $\begin{array}{l}\text { U.S Census data, } \\
\text { age of residential } \\
\text { building, market } \\
\text { value change, } \\
\text { higher property } \\
\text { taxes }\end{array}$ & $\begin{array}{l}\text { Utilized GIS for visualization of housing } \\
\text { stock value and property tax changes. }\end{array}$ & $\begin{array}{l}\text { Yes, accounted } \\
\text { for residential } \\
\text { property age and } \\
\text { price in the study } \\
\text { area. }\end{array}$ & $\begin{array}{l}\text { Inconsistent } \\
\text { scale, } \\
\text { insufficient } \\
\text { analysis, } \\
\text { insufficient } \\
\text { Census } \\
\text { Indicators. }\end{array}$ \\
\hline $\begin{array}{l}\text { Chapple } \\
(2009)\end{array}$ & $\begin{array}{l}\text { Susceptibility to } \\
\text { gentrification, } \\
\text { susceptibility is defined } \\
\text { by changes in Census } \\
\text { Indicators. }\end{array}$ & $\begin{array}{l}\text { County, Neighborhood, Tracts, } \\
\text { and Block Groups. }\end{array}$ & $\begin{array}{l}\text { A predictive gentrification } \\
\text { index is created based on } \\
\text { susceptibility (no, low, } \\
\text { moderate, and high). }\end{array}$ & $\begin{array}{l}\text { U.S census data. } \\
\text { Housing stock } \\
\text { quality, location, } \\
\text { and price. }\end{array}$ & $\begin{array}{l}\text { Regression determines selection and } \\
\text { impact of variables on gentrification } \\
\text { measurement. }\end{array}$ & $\begin{array}{l}\text { Yes, accounts for } \\
\text { unique } \\
\text { characteristics of } \\
\text { housing and } \\
\text { transportation. }\end{array}$ & $\begin{array}{l}\text { Inconsistent } \\
\text { scale, not all } \\
\text { data sources } \\
\text { are specified. }\end{array}$ \\
\hline
\end{tabular}




\begin{tabular}{|c|c|c|c|c|c|c|c|}
\hline Study & $\begin{array}{c}\text { Definition of } \\
\text { gentrifying/gentrified }\end{array}$ & Unit/Scale of analysis/model & $\begin{array}{l}\text { Stages/Index/Measure } \\
\text { of Gentrification }\end{array}$ & Indicators & Methods & $\begin{array}{l}\text { Accounts for } \\
\text { Unique local } \\
\text { characteristics? }\end{array}$ & Limitations \\
\hline $\begin{array}{l}\text { Gafvert } \\
(2011)\end{array}$ & $\begin{array}{l}\text { Median household } \\
\text { change }\end{array}$ & Census Tracts. & $\begin{array}{l}\text { Future/possible } \\
\text { gentrification. }\end{array}$ & $\begin{array}{l}\text { U.S Census data, } \\
\text { city data, local } \\
\text { housing experts } \\
\text { surveys }\end{array}$ & $\begin{array}{l}\text { Created weights for various indicators } \\
\text { using surveys. }\end{array}$ & $\begin{array}{l}\text { Yes, accounted } \\
\text { for local } \\
\text { characteristics } \\
\text { through the } \\
\text { survey. }\end{array}$ & $\begin{array}{l}\text { A finer scale/ } \\
\text { small study } \\
\text { sample. }\end{array}$ \\
\hline $\begin{array}{l}\text { Papachristos } \\
\text { et al. (2011) }\end{array}$ & $\begin{array}{l}\text { Based on literature } \\
\text { definitions and included } \\
\text { new indicators, number } \\
\text { of coffee shops, and } \\
\text { crime rates. }\end{array}$ & $\begin{array}{l}\text { Neighborhood Clusters } \\
\text { comprised of 20-30 census } \\
\text { tracts. }\end{array}$ & Post gentrification. & $\begin{array}{l}\text { U.S Census data, } \\
\text { coffee shops, } \\
\text { crime } \\
\text { (specifically } \\
\text { violent crime). }\end{array}$ & $\begin{array}{l}\text { Descriptive analysis of the spatial and } \\
\text { temporal data combined with longitudinal } \\
\text { Poisson modeling }\end{array}$ & Yes. & Scale. \\
\hline Fouch (2012) & $\begin{array}{l}\text { Changes in indicators } \\
\text { and through field work } \\
\text { in the form of site visits. }\end{array}$ & Block Groups & $\begin{array}{l}\text { Future gentrification } \\
\text { (Vulnerability) }\end{array}$ & $\begin{array}{l}\text { U.S Census Data, } \\
\text { housing/property } \\
\text { data, amenities, } \\
\text { build } \\
\text { environment } \\
\text { conditions site } \\
\text { visit observations }\end{array}$ & $\begin{array}{l}\text { A combination of statistical analysis of } \\
\text { census variables, GIS suitability } \\
\text { modeling, and qualitative field work. }\end{array}$ & Yes. & Scale. \\
\hline Scott (2013) & $\begin{array}{l}\text { Change in local housing } \\
\text { market. }\end{array}$ & City Ward. & Past gentrification & $\begin{array}{l}\text { U.S census data, } \\
\text { Housing } \\
\text { Authority data, } \\
\text { home sales, home } \\
\text { rental prices, and } \\
\text { interviews. } \\
\end{array}$ & $\begin{array}{l}\text { Descriptive Statistics, policy analysis, } \\
\text { and mixed methods approach with a } \\
\text { focus on interviews. }\end{array}$ & Yes. & $\begin{array}{l}\text { Scale, not a } \\
\text { direct measure } \\
\text { of } \\
\text { gentrification. }\end{array}$ \\
\hline Welch (2013) & $\begin{array}{l}\text { Demographic } \\
\text { indicators. }\end{array}$ & $\begin{array}{l}\text { Census Tract, Raster Cell size of } \\
100 \text { feet }\end{array}$ & $\begin{array}{l}\text { Future gentrification } \\
\text { (Susceptibility). }\end{array}$ & $\begin{array}{l}\text { U.S census data, } \\
\text { City data, local } \\
\text { amenities. }\end{array}$ & $\begin{array}{l}\text { Created a weighted index to detect } \\
\text { susceptibility. Attempted to account for } \\
\text { finer scale by transition to raster units of } \\
\text { measurement. }\end{array}$ & $\begin{array}{l}\text { Yes. Accounted } \\
\text { for unique } \\
\text { characteristics } \\
\text { during indicator } \\
\text { and weights } \\
\text { selection. }\end{array}$ & $\begin{array}{l}\text { Scale } \\
\text { inconsistencies. }\end{array}$ \\
\hline $\begin{array}{l}\text { Maantay \& } \\
\text { Maroko } \\
(2018)\end{array}$ & $\begin{array}{l}\text { Based on traditional } \\
\text { literature. }\end{array}$ & Census Block groups. & $\begin{array}{l}\text { Past and current } \\
\text { gentrification. }\end{array}$ & $\begin{array}{l}\text { U.S Census data, } \\
\text { proximity to } \\
\text { community } \\
\text { Gardens in NYC, } \\
\text { NY. }\end{array}$ & $\begin{array}{l}\text { Hot Spot Cluster Analysis, Proximity } \\
\text { Getis-Ord GI Statistics with distance } \\
\text { thresholds were used to assess the } \\
\text { proximity of gentrified/gentrifying } \\
\text { Census Block Groups to community } \\
\text { garden. }\end{array}$ & Yes. & $\begin{array}{l}\text { Small selection } \\
\text { of Census and } \\
\text { demographic } \\
\text { variables } \\
\text { without } \\
\text { accounting for } \\
\text { housing } \\
\text { conditions. }\end{array}$ \\
\hline
\end{tabular}




\begin{tabular}{|c|c|c|c|c|c|c|c|}
\hline \multicolumn{8}{|c|}{ Table 1(continued): Comparison of a Sample of Studies with New Approaches to Measuring Gentrification } \\
\hline Study & $\begin{array}{l}\text { Definition of } \\
\text { gentrifying/gentrified }\end{array}$ & Unit/Scale of analysis/model & $\begin{array}{l}\text { Stages/Index/Measure } \\
\text { of Gentrification }\end{array}$ & Indicators & Methods & $\begin{array}{l}\text { Accounts for } \\
\text { Unique local } \\
\text { characteristics? }\end{array}$ & Limitations \\
\hline $\begin{array}{l}\text { Braswell } \\
(2018)\end{array}$ & $\begin{array}{l}\text { Based on traditional } \\
\text { literature. }\end{array}$ & $\begin{array}{l}\text { Census Tracts converted into } \\
\text { one square kilometer grid } \\
\text { squares. }\end{array}$ & $\begin{array}{l}\text { Past and current } \\
\text { gentrification. }\end{array}$ & $\begin{array}{l}\text { U.S Census data, } \\
\text { proximity to } \\
\text { community } \\
\text { Gardens in St. } \\
\text { Louis, Mo. }\end{array}$ & $\begin{array}{l}\text { Spatial interpolation to divide the City } \\
\text { into one square kilometer grid squares. } \\
\text { Intersection and overlay to determine } \\
\text { proximity of a gentrifying grid (Census } \\
\text { data) to a garden, spatial regression to } \\
\text { determine relationship between a } \\
\text { gentrification and presence of gardens. }\end{array}$ & $\begin{array}{l}\text { Yes. Local data } \\
\text { was sourced. }\end{array}$ & $\begin{array}{l}\text { Selection of } \\
\text { methodology } \\
\text { (grid squares } \\
\text { do not } \\
\text { represent a } \\
\text { real-world, } \\
\text { functional } \\
\text { neighborhood) }\end{array}$ \\
\hline $\begin{array}{l}\text { Glaeser et al. } \\
\text { (2018) }\end{array}$ & $\begin{array}{l}\text { Based on traditional } \\
\text { literature. }\end{array}$ & $\begin{array}{l}\text { ZIP Codes, Census Tracts, and } \\
\text { Block Level (Streetscore is } \\
\text { defined by another cited study). } \\
\text { Streetscore is a computer } \\
\text { generated measure of perceived } \\
\text { safety. }\end{array}$ & $\begin{array}{l}\text { Past and current/ongoing } \\
\text { gentrification. }\end{array}$ & $\begin{array}{l}\text { U.S Census data, } \\
\text { and Yelp (social } \\
\text { media platform) } \\
\text { data. }\end{array}$ & $\begin{array}{l}\text { Extensive Correlation analysis. Positive } \\
\text { correlation between various businesses } \\
\text { associated/preferred by educated higher } \\
\text { income earners and Census demographics } \\
\text { indicative of educated higher income } \\
\text { earners. }\end{array}$ & Yes. & $\begin{array}{l}\text { Inconsistent } \\
\text { scale and level } \\
\text { of geography. } \\
\text { A higher } \\
\text { application of } \\
\text { GIS and } \\
\text { mapping } \\
\text { analysis is } \\
\text { desired. } \\
\end{array}$ \\
\hline $\begin{array}{l}\text { Aike et al. } \\
\text { (2018) }\end{array}$ & $\begin{array}{l}\text { Study specific } \\
\text { definition of urban } \\
\text { change based on local } \\
\text { rent increases and } \\
\text { increases in perceived } \\
\text { desirability and } \\
\text { livability. }\end{array}$ & $\begin{array}{l}\text { Metropolitan Statical Areas } \\
\text { (MSAs), study specific } \\
\text { neighborhoods/tracts in Chicago, } \\
\text { New York City, Los Angeles, } \\
\text { Boston, and Portland. }\end{array}$ & $\begin{array}{l}\text { Detecting recent/current } \\
\text { and forecasting future } \\
\text { change in rental prices for } \\
\text { neighborhoods becoming } \\
\text { more desirable }\end{array}$ & $\begin{array}{l}\text { U.S Census data, } \\
\text { and Twitter } \\
\text { (social media } \\
\text { platform) data. }\end{array}$ & $\begin{array}{l}\text { Correlation between traditional Census } \\
\text { Indicators of change (Housing Price and } \\
\text { Income Change) and Spatial Tweeter } \\
\text { Data including number of users, number } \\
\text { of tweets, and number of user visits } \\
\text { within a specific neighborhood (number } \\
\text { of distinct days in one year a user was } \\
\text { geolocated within the neighborhood). }\end{array}$ & Yes. & $\begin{array}{l}\text { An excellent } \\
\text { and innovative } \\
\text { study. }\end{array}$ \\
\hline $\begin{array}{l}\text { Ilic et al. } \\
(2019)\end{array}$ & $\begin{array}{l}\text { Based on traditional } \\
\text { literature. }\end{array}$ & $\begin{array}{l}\text { Census Tracts, Individual } \\
\text { Building Permits Data, and } \\
\text { Google Street View data. }\end{array}$ & $\begin{array}{l}\text { Past, current, and possibly } \\
\text { forecast future } \\
\text { gentrification. }\end{array}$ & $\begin{array}{l}\text { Canadian Census } \\
\text { data, Ottawa } \\
\text { Building Permits, } \\
\text { and Google Street } \\
\text { View data. }\end{array}$ & $\begin{array}{l}\text { Utilized deep Machine Learning and } \\
\text { methodology established by Naik et al. } \\
\text { (2014) to build and train a robust } \\
\text { Siamese convolutional neural network } \\
\text { (SCNN) model that automatically detects } \\
\text { gentrification-like visual changes in } \\
\text { temporal sequences of Google Street } \\
\text { View. Validated model accuracy with } \\
\text { Building Permits. }\end{array}$ & Yes. & $\begin{array}{l}\text { No limitations. } \\
\text { An excellent } \\
\text { and innovative } \\
\text { study. }\end{array}$ \\
\hline
\end{tabular}




\begin{tabular}{|c|c|c|c|c|c|c|c|}
\hline Study & $\begin{array}{l}\text { Definition of } \\
\text { gentrifying/gentrified }\end{array}$ & Unit/Scale of analysis/model & $\begin{array}{l}\text { Stages/Index/Measure } \\
\text { of Gentrification }\end{array}$ & Indicators & Methods & $\begin{array}{l}\text { Accounts for } \\
\text { Unique local } \\
\text { characteristics? }\end{array}$ & Limitations \\
\hline $\begin{array}{l}\text { Mann and } \\
\text { Bennet (2020) }\end{array}$ & $\begin{array}{l}\text { Based on traditional } \\
\text { literature. }\end{array}$ & $\begin{array}{l}\text { Census Tracts, point locations of } \\
\text { individuals schools. }\end{array}$ & $\begin{array}{l}\text { Past and current } \\
\text { gentrification. }\end{array}$ & $\begin{array}{l}\text { Census Tracts, } \\
\text { School Data and } \\
\text { Statistics (Charter } \\
\text { and Public } \\
\text { Schools and } \\
\text { demographics } \\
\text { within those } \\
\text { schools) }\end{array}$ & $\begin{array}{l}\text { Utilized statistical analysis of Census } \\
\text { indicators (race and income focused) to } \\
\text { create gentrification indices. Employed a } \\
\text { standard GIS analytics approach } \\
\text { (intersects) to identify relationships } \\
\text { between gentrifying areas and the } \\
\text { implementation of charter schools within } \\
\text { those areas. Analyzed school } \\
\text { demographics within the different areas } \\
\text { to further assess relationship. }\end{array}$ & Yes. & $\begin{array}{l}\text { Well } \\
\text { researched and } \\
\text { deep analyzed } \\
\text { study. }\end{array}$ \\
\hline $\begin{array}{l}\text { Barton et al.et } \\
\text { al.(2020) }\end{array}$ & $\begin{array}{l}\text { Based on traditional } \\
\text { literature. }\end{array}$ & $\begin{array}{l}\text { Census Tracts. Crime data } \\
\text { points. }\end{array}$ & $\begin{array}{l}\text { Past and current } \\
\text { gentrification. }\end{array}$ & $\begin{array}{l}\text { U.S Census data, } \\
\text { LA Country } \\
\text { Homicides data. }\end{array}$ & $\begin{array}{l}\text { Created indices using factor analyses and } \\
\text { a spatial weights matrix (combined } \\
\text { Census data with crime data). Used } \\
\text { Spatial autocorrelation to detect } \\
\text { gentrification Hotspots. }\end{array}$ & Yes. & $\begin{array}{l}\text { Scale, tempora } \\
\text { period, focus } \\
\text { on only one } \\
\text { neighborhood. }\end{array}$ \\
\hline
\end{tabular}


All the studies presented in Table 1 utilize Census variables as indicators of gentrification, with favorable fluctuations in literature-defined Census variables signaling or supporting the claimed presence of the phenomena. Upon careful observation certain themes emerge in terms of selections for additional non-Census based indicators. Many of the studies that incorporate additional indicators either focus on physical improvements to the conditions of the housing stock and the appreciation of the housing market or look to specific social (crime and geographically relevant social media activity) or commercial variables (businesses that are usually associated with more affluent gentrifying demographics).

Studies that focused on housing characteristics/housing conditions include Gambrill (2007), Heidkamp and Lucas (2007), Levy (2009), Chapple (2009), Fouch (2012), Scott (2013), and Ilic et al.(2018). These studies paid close attention to the value, age, condition, and the location of housing, and how gentrification has affected the housing market or the built environment. Both Gambrill and Levy utilized individual housing property data. Each study assessed changes in housing prices, with Levy focusing on property taxes while Gambrill deciding to leverage a pay-to-use private sector real estate database. The addition of individual properties adds a compelling large-scale aspect. The Heidkamp and Lucas study and the Fouch study validated the conditions of the housing stock through field surveys and site visits to gentrifying neighborhoods. The additions of field surveys provide a valuable independent confirmation of the built environmental conditions, create a series of photographic evidence detailing the physical changes, and help determine the stage and magnitude of gentrification. The Ilic et al.(2018) study focused on the built environment and analyzing physical change on an individual housing basis. This excellent study utilized cutting edge innovative machine learning technology to detect temporal changes in a large dataset of Google Street View images. The output results of the machine learning analysis were validated through comparison to Building Permits and census data. Two additional studies, Brasewell (2018) and Maantay \& Maroko (2018), concentrated on a physical neighborhood characteristic or a physical amenities, selecting the establishment of new "green spaces", specifically community gardens, as indicative of gentrification growth.

O’Sullivan (2004), Papachristos et al. (2011), and Barton et al.(2020) all focused on crime. These studies highlighted a decrease in crime, especially violent or property crimes, as signs of gentrification. All three used some type of regression or statistical analysis to link a temporal decrease in crime with gentrification (defined through Census indicators). In addition to crime, Papachristos also infused a distinct commercial element, the establishment of high-end coffee-shops, to highlight the growth of gentrification. Mann and Bennet (2020) chose to use educational indicators and focused on determining a relationship between gentrifying areas and an increase in the establishment of charter schools. They also analyzed the population compositions of charter and public schools to further explore the impact of gentrification on the demographic configurations within each school type. 
Two studies that leveraged the power of social media platforms and big open data in complementing traditional Census indicators are Aike et al., (2018) and Glaeser et al., (2018). Aike et al. (2018) applies Twitter Geolocation data, examining the number of visits or tweets originating from within the boundaries of a specific neighborhood in conjunction with Census indicators to forecast which neighborhoods will experience future rent increases and desirability growth (and possible gentrification). Glaeser et al., (2018) harnesses the power of Yelp to explore the commercial aspects of urban change and gentrification. This study defines specific business types usually associated with more affluent demographics such as high-end eateries (vegetarian or "new-age"), coffee shops (franchise chains and boutiques), and yoga/fitness studios. After defining businesses usually associated with more affluent demographics, Glaeser et al. (2018) conducted a detailed correlation analysis between the number of newly opened high-end business and Census demographic variables indicative of gentrification.

The diversity of the indicator variables observed across different gentrification studies is also reflected in the varied applications of GIS techniques employed in spatially identifying, measuring, and assessing the process. The next section delves into the various techniques applied in spatially analyzing gentrification, with a focus on grouping together studies that utilize similar GIS assessment approaches.

\subsection{Application of GIS in measuring Gentrification}

In modern gentrification literature, GIS is usually employed to make comparisons, to detect changes and to forecast future susceptibility to change. The prevailing application of GIS frequently takes the form of temporal change analysis, comparing the socio-demographic and/or built environmental conditions before, during, and after gentrification. Other frequent applications of GIS focus on discovering or identifying "hotspots" or areas of high concentration, and different visualization techniques. Advances in GIS technology over the past decade have allowed gentrification studies to take advantage of the powerful spatial analysis and statistical capabilities of modern GIS software. A popular GIS methodology that was utilized by a few different studies from Table1 (Nesbitt, Chappele, Fouch, Welch, Maantay \& Maroko, and Braswell) is weighted overlay analysis in the form of suitability modeling. Weighted overlay analysis allows users to execute suitability models and to create comprehensive gentrification indices. Fouch, Welch, and Brasewell converted the vector-based data to fishnet rasters to create a common unit, and to achieve a finer scale beyond the Census based administrative boundaries. These studies claimed a benefit from having a common raster based parametric unit of measurement that granted a more detailed effortless comparison across the entire study area. However, local neighborhood and natural physical characteristics could be lost or omitted during the conversion process, and a certain level of error could be also introduced.

For stellar examples of studies that look to escape the restrictions of administrative boundaries, the analyses presented by Ilic et al.(2018) and Aike et al. (2018) should be reviewed. 
Both studies take advantage of expansive data to penetrate to the finest levels of scale and geography. Illic et al. (2018) used a combination of Google Street View imagery and Building Permits to identify gentrifying areas, while Aike et al. (2018) capitalized on the geolocation of twitter data to forecast future areas of rent increase. Both these studies exceeded the confines of administrative boundaries, with Illlic et al. (2018) stating that the results from their Machine Learning model are able to "show if two blocks gentrify around a boundary. This could aid in validating or decomposing the results of Census-based inferences about gentrification in urban areas" (p 16). Although both these studies successfully achieve a scale beyond administrative boundaries, they still refence Census Data as validation source or to reinforce the results of their new indicator assessments.

As more city and local governments align with initiatives to make big public data more readily available, more scholars should embrace the power of GIS in measuring and visualizing gentrification and in using it for studying various urban phenomena. With modern studies analyzing and measuring gentrification with innovative forward leading technologies and advanced GIS tools, consistent methodological approaches are emerging. This study hopes to contribute to new emerging methodological assessments of gentrification through the addition of a large-scale GIS-based measurement approached focused on Building Permits.

\section{Case Study}

Gentrification is not only transforming the neighborhoods and communities within Washington D.C, but it is fundamentally changing the face and image of certain segments of the city. Both the built physical environments and unique social community characteristics in the gentrifying areas are being altered. Employing a GIS centered approach in conjunction with big open public data, this study will aim to measure the distribution, extent, and intensity of gentrification in Washington D.C on a census Block Group level. The study will validate the accuracy of the new approach by through validation against reports of gentrification by local media sources.

Washington D.C is a city recognized for its historical landmarks, a diverse international population, exceptional entertainment, and a variety of cultural amenities. It also has a reputation as one of the most rapidly changing areas of the country (Plerhoples et al, 2015). A city with an eclectic and significant African American population, in the past decade the District has seen a large influx of white residents that are transforming its composition (Shinault and Seltzer, 2019). Table 2 below presents a summary of Census data capturing the change across key demographics. It must be noted that Census collection techniques, parameters, and data fields have been transformed over the years, and change analyses for certain indicators are not possible. 
Table 2: Census Demographics for Washington DC 2010-2019

\begin{tabular}{|c|c|c|c|}
\hline Demographic and Housing Indicators Change* & 2010 & 2019 & $\begin{array}{l}\text { Percent/Dollar } \\
\text { Change }\end{array}$ \\
\hline Population estimates & 601,767 & 705,749 & $17.3 \%$ \\
\hline \multicolumn{4}{|l|}{ Age } \\
\hline Persons under 5 years, percent & 5.4 & 6.4 & 1.0 \\
\hline Persons under 18 years, percent & 16.7 & 18.2 & 1.5 \\
\hline Persons 65 years and over, percent & 11.4 & 12.4 & 1.0 \\
\hline Median Age & 33.8 & 33.9 & 0.1 \\
\hline \multicolumn{4}{|l|}{ Race } \\
\hline White alone, percent (a) & 38.5 & 46.0 & 7.5 \\
\hline Black or African American alone, percent(a) & 50.7 & 46.0 & -4.7 \\
\hline Asian alone, percent(a) & 3.5 & 4.5 & 1.0 \\
\hline Hispanic or Latino, percent(b) & 9.1 & 11.3 & 2.2 \\
\hline \multicolumn{4}{|l|}{ Housing Characteristics } \\
\hline Housing Units & 296,719 & 322,793 & 26,074 \\
\hline Owner-occupied housing units' rate & 37.7 & 41.8 & 4.1 \\
\hline Median value of owner-occupied housing units & $\$ 426,900$ & $\$ 568,400$ & $\$ 141,500(33.5 \%)$ \\
\hline Median selected monthly owner costs -with a mortgage, 2014-2018 & $\mathrm{N} / \mathrm{A}$ & $\$ 2,456$ & $\mathrm{~N} / \mathrm{A}$ \\
\hline Median selected monthly owner costs -without a mortgage, 2014-2018 & $\mathrm{N} / \mathrm{A}$ & $\$ 672$ & $\mathrm{~N} / \mathrm{A}$ \\
\hline Median gross rent & $\mathrm{N} / \mathrm{A}$ & $\$ 1,487$ & $\mathrm{~N} / \mathrm{A}$ \\
\hline \multicolumn{4}{|l|}{ Families and Living Arrangements } \\
\hline Households & 266,707 & 281,322 & 14,615 \\
\hline Persons per household & 2.1 & 2.29 & 0.19 \\
\hline \multicolumn{4}{|l|}{ Income \& Poverty } \\
\hline Median Household income & $\$ 60,903$ & $\$ 82,604$ & $\$ 21,701(35.63 \%)$ \\
\hline Per capita income in past 12 months & $\$ 40,797$ & $\$ 53,321$ & $\$ 12,524(30.70 \%)$ \\
\hline Persons in Poverty, percent & 17.2 & 13.5 & -3.7 \\
\hline \multicolumn{4}{|l|}{ Education } \\
\hline High school graduate or higher, percent of persons age $25+$, percent & $\mathrm{N} / \mathrm{A}$ & 90.6 & $\mathrm{~N} / \mathrm{A}$ \\
\hline Bachelor's degree or higher, percent of persons age $25+$, percent & $\mathrm{N} / \mathrm{A}$ & 57.6 & $\mathrm{~N} / \mathrm{A}$ \\
\hline \multicolumn{4}{|c|}{$\begin{array}{l}\text { *Census data collection methodology and data collection fields/variables have changed from } 2010 \text { to } 2019 \text {. Data sourced } \\
\text { from: (2010) https://planning.dc.gov/page/population, (2010) https://planning.dc.gov/page/dc-census-2010-data, } \\
\text { (2019)https://www.census.gov/quickfacts/DC. } 2019 \text { data estimates are from an early release of the } 20195 \text { Years ACS. } \\
\text { (a)Includes persons reporting only one race. (b)Hispanics may identify within any race. }\end{array}$} \\
\hline
\end{tabular}

Between the 2010 Decennial Census and the most recent 2019 5-year ACS estimates, the population within the city of Washington D.C saw a sizable increase of $17.3 \%$, clearly indicating that the city is a vigorously growing urban area (U.S Census Bureau, 2010; U.S Census Bureau, 
2019). The demographic changes during the same time are significant. The percent of residents identifying as Black Only/African American alone decreased from 50\% to 46\%. In contrast the population of almost every other ethnic group increased, the percent of White residents increased from $38.5 \%$ to $46 \%$, Hispanic residents increased by from $9.1 \%$ to $11.3 \%$, and the percent of Asian residents increased by 1 percentage point.

The incomes of the residents have also seen a marked increase, with many new residents belonging to the middle and upper socioeconomic classes and bringing the city's overall median income up from $\$ 60,903$ to $\$ 82,604$. To accommodate the growing population, over 25,000 new housing units (HUs) have been added (either from new construction or from conversions).

Residents are more likely to own their new homes, and the percent of owner-occupied dwellings increased by $4.1 \%$. The median prices of homes also saw a significant increase of $33.15 \%$ during rising from $\$ 426,900$ in 2010 , to an estimated $\$ 568,400$ in 2019, (U.S Census 2010, 2019; GCAAR, 2019). Since the 2010 Decennial Census collected education data according to different parameters, this study could not conduct a change assessment. Data for monthly owner costs was also unavailable, but based on the rising costs of housing, an assumption can be made that owner costs rose as well.

The gentrification that has taken place in Washington D.C has changed the character and nature of entire neighborhoods. The influx of higher income residents into the city has elevated or introduced new commercial enterprises (Green et al., 2017), but also resulted in a fairly rapid increase in living costs, housing prices, and a marked change to racial and ethnic demographics. As a result, the City has experienced a change to its image, improvements to the physical built environment within certain neighborhoods, and a metamorphosis of residents' perceptions of their own city (Green et al., 2017; Shinault and Seltzer, 2019). There have been some negative consequences such as displacement or a self-initiated exodus of those unable to afford the new costs of living. This type of displacement can sometimes be coupled with a loss in diversity and neighborhood culture, but exploring these effects is not within scope of this study (Leonnig, 2004; Murphy, 2004; Wilgoren and Salmon, 2004a; Wilgoren and Salmon 2004b; Sommer, 2012;Franke-Ruta, 2012).

\section{Research Questions}

1. Does detailed Building Permit data, provide an accurate large-scale assessment of the spatial distribution, and intensity of gentrification in Washington D.C?

2. Does the Washington D.C case study demonstrate that Building Permit data, combined with traditional Census modes of measurement, provide an enhancement in the measurement of gentrification? 


\section{Analysis}

\subsection{Data Overview}

The data explored, acquired, and analyzed in this study originated from three primary sources, the U.S Census American Community Survey, the Washington D.C Department of Consumer and Regulatory Affairs (DCRA), and local newspaper sources and blogs. The American Community Survey data was obtained using the Census Factfinder, which streamlined data acquisition and allowed for the identification and extraction of specific ACS data ranges within pre-defined units of census geography. From survey to survey, the Census can modify data collection parameters or omit data collection or data releases at certain levels of geographic scale (U.S Census Bureau, 2018). The Factfinder allowed for smooth data exploration and was crucial in ensuring indicator consistency across identical units of geography (Block Groups). Unfortunately, as of March 2020, the Factfinder service has been discontinued, and the Census transitioned to a new data portal, data.census.gov (U.S Census, 2020). It appears that conversion of Factfinder data is still ongoing, and certain indicators or scales of geography are still in progress to be migrated to the new data portal.

The Building Permits data was acquired directly from the Washington DCRA GIS data portal (DCRA, 2011-2017). The topology and boundaries for the geographic administrative Census units including Census Block Groups and DC Boundary lines, were acquired from the Government of the District of Columbia GIS Site (Government of the District of Columbia, 2020). In late 2016, DCRA redesigned and updated their Building Permits portal site, removing all Building Permits older than 2016, and updating and redesigning the permit categories. Fortunately, this study curated older data extending back to 2011, mitigating a negative impact to the data integrity and temporal extent for the Building Permits dataset.

Through extensive research of local and national media sites this study documented media coverage of gentrification overlapping the studies temporal period. The frequency a media source identified a gentrifying neighborhood was aggregated to the closest Washington D.C designated Neighborhood Cluster. This method allowed the study to combine the data for disparate media sources and represent them in the form of gentrifying neighborhood hotspots (through a sum count of how many times each study mentioned a specific gentrifying neighborhood area).

\subsection{Tools, Methods and Techniques}

\subsubsection{Weights Development Method}

Following the methodology established in gentrification literature, this study looked to create a weighted composite index for both the Census Indicators and Building Permits. A 
weighted composite index allows for the combination of multiple variables and an emphasis of certain variables over others (Census Indicators or a Building Permits that tend to be more aligned with a gentrification-based change should receive a higher weight). While there is a spectrum of techniques that can be used to create weights from factor analysis to principal component, the qualitative nature of gentrification and the study specific variations in analytical approaches implore for a method that complements qualitative data and is able to evaluate both the tangible and intangible aspects of gentrification.

Utilizing a systematic comprehensive approach for weights development creates a standard that can be replicated by other studies and considers the qualitative user infused aspects of the measuring the phenomena. While studies can rely on traditional gentrification literature to develop a general approach to creating a hierarchy for Census indicators (emphasizing the importance of indicators such as income, housing conditions, housing values, rent costs, and race), developing a hierarchy for Building Permits, or another future novel measure of gentrification, is more challenging.

This study chose to employ the Analytical Hierarchy Process (AHP) created by Thomas L. Saaty as a simple and effective method for weights development. AHP can be oriented to assess qualitative data and is often leveraged in making complex decisions involving multiple stakeholders in corporate or business environments. Saaty (1987) describes the efficacy of using an AHP approach for ranking or measuring both tangible (physical) and intangible (psychologic) phenomena:

\footnotetext{
"people have been concerned with the measurement of both physical and psychological events. By physical we mean the realm of what is fashionably known as the tangibles as it relates to some kind of objective reality outside the individual conducting the measurement. By contrast, the psychological is the realm of the intangibles as it relates to subjective ideas and beliefs of the individual about himself or herself and the world of experience. The question is whether there is a coherent theory that can deal with both these worlds of reality without compromising either. The AHP is a method that can be used to establish measures in both the physical and social domains." (pg. 161)
}

AHP is an excellent method for decision making or problem solving within new spheres of measurement or where robust standards are yet to be established, "In completely new decision problems or in old problems where no standards have been established, we must continue to use relative measurement comparing alternatives in pairs to identify the best" (Saaty, 1987, p.173).

According to Saaty (2013), one of the greatest benefits that AHP provides is to systematically organize decision making or ranking, "Complex decision-making needs organized creative thinking to structure a problem. This structure can be provided by a hierarchy or a network. It also needs numbers and a modicum of mathematics to formalize judgments and make trade-offs" (p. 1101). At the heart of AHP is the utilization of a pairwise comparison approach that ranks the importance of each variable against all other variables in a dataset, establishing a 
hierarchy and weights through this process. The values dictated by Saaty (2013) for pairwise comparison:

"The following numbers are to be assigned in making paired comparisons: equal with (value 1), moderate with (value 3), strong with (value 5), very strong with (value 7) and extreme with(value 9) and the integers between for compromise, and their reciprocals" (p. 1101) .

Using AHP the researcher is able to rely on the core tenents of the process, "Three principles guide one in problem solving using the AHP: decomposition, comparative judgments and synthesis of priorities" (Saaty, 1987, p. 166), applying them systematically to establish hierarchy and weights within any dataset, even if the literature for hierarchy/weights development is lacking or conflicting. By selecting AHP, this study hopes to coalesce around a standard that can be used for future ranking of Building Permits (and/or Census Indicators) within other cities or regions, establishing a systematic ranking methodology while still accounting for unique local and regional characteristics.

\subsubsection{Statistical Methods}

In this study Descriptive Statistics was critical in exploratory data analysis, in helping make decisions on weights and hierarchy parameters, and in assessing relationships between the separate indices. Determining the mean, median, and/or sums and standard deviations for both the Building Permits and the Census Indicators was essential in understanding the spread and distribution of various study assessed metrics. Statistical tools/techniques included:

1. Excel - Power pivots for assessing mean, median, sums and standard deviations for study selected Census Indicators and Building Permits. Correlation analysis to determine relationship between the individual indices.

2. Minitab - visual descriptive statistics. Assessed the distribution of Household Income, and critical for determining exclusions (mean $+1 \mathrm{Std}$ ) for areas to affluent to gentrify.

\subsubsection{GIS Methods}

In this study GIS was indispensable in assessing the spatial aspects of gentrification. The sequence of GIS analysis techniques and methods is described in the analytic process model (APM) section. A summary of the main techniques utilized is below (Anselin and GeoDa, 2020; ESRI, 2020):

1. Spatial Join Analysis - Joining the attributes from one feature to another based on a spatial relationship. This study used the intersect spatial relationship.

- Target features: Census Block Groups

- Joined attributes from the join features: Building Permits 2011 -2017. Summed by count (a total count of each Building Permit category within each Block Group) and Total Value per Building Permit category within each Block Group (each Building Permit has a total value paid associated with it). 
2. Table Join Analysis - Joining a table of data to a feature class or a spatial layer based on a common specific field that can be found within both data elements.

- Target feature: Census Block Groups

- Joined attributes from the join features: Selected Census Indicators percent change (ACS2017 - ACS2013). The common element for the joins was the unique GEOID name for each Block Group.

3. (ArcGIS) Geographically Weighted Regression (GWR) - a form of regression that can be used to model spatially varying relationships based on dependent and explanatory variables.

○ Dependent Variable: Census Gentrification Index.

- Explanatory Variable: Build Permits Gentrification Index.

- A technique to determine spatial autocorrelation and to detect significant relationships between two sets of weighted features or variables. GWR is effective for identifying if the local correlation is direct or inverse within a specific feature or a within a prespecified geographic area. Additional techniques can be employed to investigate clustering of outliers and to validate GWR results.

4. Moran's I Statistic (supplementary analysis to validate GWR) - This technique identifies statistically significant variable relationships within features, but can also highlight a clustering of outliers within a prespecified geographic area. Moran's I can helps uncover "hot spots" or areas where high values are surrounded by other high values or the inverse "colds spots" or areas where low values are surrounded by other low values. This study used the Bivariate Moran's I to visually validate and supplement the spatial outputs of the GWR analysis. A closer integration between analysis methods is hoped to be achieved in future work.

\subsection{Development of Individual Indices}

\subsubsection{Census Indicators Index}

This study selected Census Housing and Demographic Indicators based on those consistently found in the literature, with a focus on studies utilizing housing indicators in conjunction with GIS to measure, assess, or visualize gentrification (Gambrill, 2007; Heidkamp and Lucas, 2007; Levy ,2009; Chapple, 2009; Fouch, 2012, Scott, 2013; and Ilic et al, 2018). While many traditional gentrification studies tend to include variables that focus on distinct racial or family characteristics, this study decided to concentrate on economic indicators, with an emphasis on income and HUs conditions. Since Washington D.C is a very diverse city with a significant transient population of students and temporary domestic and international residents (Jiang et al, 2019), relying on traditional indicators of race, age, and household composition may introduce an imbalance unrepresentative of gentrification and obscuring its actual magnitude or intensity. 
It must be noted that the ACS data employed by this study are estimates, collected through samples of the population or through samples of HUs, and are not complete full counts such as those conducted during the Decennial Censuses (U.S Census, 2018). When research for this study was initiated the 5-year 2013 and the 5-year 2017 ACS estimates were chosen because they offered the most consistent finest scale of Geography across the selected indicators. The 5year ACS estimates also provide a higher level of precision for smaller units of scale, but less temporal currency than shorter 1 and 3-year estimates (U.S Census, 2018).

Similar Census indicators were combined for simplification and certain indicators were updated to reflect current monetary values. Adhering to Saaty's guidance (Saaty, 1987) on the number of recommended variables for AHP, the number of indicators was narrowed to a total of nine. After weights were established using the AHP method, the Census indicators were multiplied by their respective weights and combined to create a Census Indicators Index. A table of selected Census indicators, associated computations, and their AHP weights is presented in the results section.

\subsubsection{Building Permits Index}

The Building Permit indicators selected for this study were based on their definitions provided by the DCRA (Appendix Table A-4) and on an extensive qualitative review of the available descriptions for each individual Building Permit type/category. For simplification and to accommodate AHP, similar Building Permit indicators were combined. Adhering to Saaty's guidance (Saaty, 1987) on the number of recommended AHP variables, the number of Building Permits indicators was narrowed to a total of 9. After weights were established using the AHP method, and after additional computations described in the APM analysis section (normalization), the Building Permit indicators were multiplied times their respective weights and combined to create a Building Permits Index. A table of selected Building Permit indicators, associated computations, and their AHP weights is presented in the results section.

\subsection{Media Sources}

This study conducted a detailed search for news articles, local blogs, and other media sources reporting on gentrification in Washington D.C. Articles within the acceptable timeframe were collated into a table, and specific references to neighborhoods were extracted. The frequency a media source identified or referenced a gentrifying neighborhood was allocated to the geographic boundaries of that neighborhood's Neighborhood Cluster feature. This method allowed the study to combine data from many different sources and to display media reports through a cartographic representation. 


\subsection{Analytical Process Model and Final Composite Index}

This study created an APM (Figure 1) to graphically represent the entire analysis process. The APM is an illustrative visualization developed to allow other studies to streamline the replication of the methodology and analysis. The activity tree in Table 3 below captures each step or activity in the APM in a table format. Activities 1.1 thru 1.15 and 2.1 through 2.14 can be conducted concurrently or consecutively.

\section{Table 3: Decision Tree for the APM}

\begin{tabular}{|c|c|}
\hline \multicolumn{2}{|c|}{$\begin{array}{l}\text { A Novel Gentrification Index (Census Data and Building Permits) } \\
\text { A Decision Tree for an APM delineating the creation of a composite Gentrification Index, } \\
\text { combining Census Indicators and Building Permits (DCRA). }\end{array}$} \\
\hline Census Indicators & Building Permits \\
\hline \multicolumn{2}{|c|}{ Conduct Data Research } \\
\hline 1.1 Research and explore the U.S Census Data & $\begin{array}{l}\text { 2.1 Research and explore the redesigned online } \\
\text { Building Permits DCRA Database }\end{array}$ \\
\hline $\begin{array}{l}\text { 1.2 Determine Survey Data Product Year } \\
\text { Availability (certain surveys are NOT conducted } \\
\text { yearly or skip years) }\end{array}$ & $\begin{array}{l}\text { 2.2 Gain an understanding of each Building } \\
\text { Permit Type and Purpose }\end{array}$ \\
\hline $\begin{array}{l}\text { 1.3 Determine Survey Data Product Scale } \\
\text { Availability (not all surveys are consistent in scale } \\
\text { from year to year) }\end{array}$ & 2.3 Determine Months/Years of Data availability \\
\hline \multicolumn{2}{|c|}{ Conduct Data Clean Up, QC, and Collation } \\
\hline $\begin{array}{l}\text { 1.4 Pull Census demographic/housing indicators } \\
\text { that are consistent across both Survey Data } \\
\text { Products and Scales (ACS 5Year + Block Groups) } \\
2013 \text { ACS-5Year } \\
2017 \text { ACS-5Year }\end{array}$ & $\begin{array}{l}\text { 2.4 Acquire data for years that complement the } \\
\text { Census Demographic Data }\end{array}$ \\
\hline 1.5 Conduct data review, QC, and data cleanup. & $\begin{array}{l}\text { 2.5 Combine with curated pre-2016 data, and } \\
\text { collate into a single Build Permits Universe that } \\
\text { temporally complements the Census Demographic } \\
\text { Data (DB: Legacy Building Permits data curated } \\
\text { by Author (Pre-2016 DCRA data cleanse and } \\
\text { redesign)) }\end{array}$ \\
\hline $\begin{array}{l}\text { 1.6 Calculate inflation adjustments (CPI) for any } \\
\text { monetary indicators (Median HH Income, Median } \\
\text { Home Value, Median Rent) }\end{array}$ & $\begin{array}{l}\text { 2.6 Conduct data review, QC, data clean up and } \\
\text { fix any geocoding errors }\end{array}$ \\
\hline $\begin{array}{l}\text { 1.7 Combine similar indicators to reduce the } \\
\text { number of demographics/housing variables (Ex: } \\
\text { Median Contract Rent combined with Median } \\
\text { Gross Rent) }\end{array}$ & $\begin{array}{l}\text { 2.7 Combine similar Building Permits to reduce } \\
\text { the number of variables(Ex: } \\
\text { Add_AddAltRep_AltRep =, Addtion+Addition } \\
\text { Alteration Repair+Alteration and Repair }\end{array}$ \\
\hline
\end{tabular}




\begin{tabular}{|c|c|}
\hline \multicolumn{2}{|c|}{ Conduct Statistical Analysis } \\
\hline $\begin{array}{l}\text { 1.8 Conduct Descriptive Statistics Analysis to } \\
\text { determine mean, median. }\end{array}$ & $\begin{array}{l}\text { 2.8 Conduct Statistics Power Pivot Analysis to } \\
\text { determine total counts, total sum, mean and } \\
\text { median for each Building Permit Category }\end{array}$ \\
\hline \multicolumn{2}{|c|}{ Conduct Appropriate Exclusions and AHP Analysis } \\
\hline $\begin{array}{l}\text { 1.9 Block Groups where ACS2013 Median HH } \\
\text { Income is above Mean + 1Std were excluded. To } \\
\text { remove unnecessary noise and to ensure only } \\
\text { appropriate Block Groups Units were analyzed } \\
\text { (already affluent Block Groups cannot gentrify) }\end{array}$ & $\begin{array}{l}\text { 2.9 Conduct extensive Qualitative Analysis to } \\
\text { exclude Building Permit categories completely } \\
\text { unrepresentative of gentrification (Sewer work, } \\
\text { fiber work, sign, etc...). Qualitative analysis } \\
\text { includes defining each permit category, and then } \\
\text { evaluation descriitions for individual permits } \\
\text { within it. }\end{array}$ \\
\hline $\begin{array}{l}\text { 1.10 Exclude Block Groups above } \\
\text { the } 40 \% \text { Coefficient of Variation were to ensure } \\
\text { data integrity (ESRI } 2017 \text { ACS White Paper) }\end{array}$ & $\begin{array}{l}\text { 2.10 Select } 9 \text { Building Permit categories to } \\
\text { accommodate the AHP method. Select categories } \\
\text { with definitions that can be associated with } \\
\text { gentrification. }\end{array}$ \\
\hline $\begin{array}{l}\text { 1.11 Determine Change between the } 2 \text { datasets } \\
\text { ACS5Year } 2017 \text { - ACS5Year2013: } \\
\text { Raw Difference } \\
\text { Percent Change }\end{array}$ & \multirow[t]{3}{*}{$\begin{array}{l}\text { 2.11 Conduct AHP analysis to determine weights. } \\
\text { Based on the qualitative analysis in } 2.9 \text {, categories } \\
\text { more representative of gentrification received } \\
\text { greater weights. }\end{array}$} \\
\hline $\begin{array}{l}\text { 1.12 Select } 9 \text { demographic/housing condition } \\
\text { indicators to narrow the Census variables to } \\
\text { accommodate the AHP method. Indicators ar } \\
\text { selected based on literature. Combine similar } \\
\text { indicators to maintain the max } 9 \text { variable count } \\
(\text { Ex: Rent }=(\text { Median Contract Rent }+ \text { Median } \\
\text { Gross Rent }) / 2))\end{array}$ & \\
\hline $\begin{array}{l}\text { 1.13 Conduct AHP analysis to determine weights. } \\
\text { Based on literature and SME knowledge, } \\
\text { indicators of Median HH Income, Median } \\
\text { Housing Value, and Median Rent received greater } \\
\text { weights. }\end{array}$ & \\
\hline \multicolumn{2}{|c|}{$\begin{array}{c}\text { AHP Weights Application, Spatial Normalization, Individual Index Creation, and Correlation } \\
\text { Assessment }\end{array}$} \\
\hline $\begin{array}{l}\text { 1.14 Join Percent Change to appropriate (non- } \\
\text { excluded) Block Groups Geography }\end{array}$ & $\begin{array}{l}\text { 2.12 Join each of the } 9 \text { selected Building Permit } \\
\text { categories to Block Groups Geography }\end{array}$ \\
\hline \multirow[t]{2}{*}{$\begin{array}{l}\text { 1.15 Multiply percent change for each } \\
\text { Demographic or Housing indicator by its } \\
\text { associated weight and combine to create the } \\
\text { Census Gentrification Index }\end{array}$} & $\begin{array}{l}\text { 2.13 Normalize the Building Permits data. } \\
\text { Total Joined Number of each BP Category } \\
\text { divided by Number of } 2010 \mathrm{HU} \text { in that Block } \\
\text { Group: } \\
\text { Joined Category/Number of } 2010 \mathrm{HU}\end{array}$ \\
\hline & $\begin{array}{l}\text { 2.14 Multiply each permit category by its } \\
\text { associated weight and combine to create the } \\
\text { Building Permits Gentrification Index }\end{array}$ \\
\hline
\end{tabular}




\section{Final Composite Index: Geographically Weighted Regression (GWR)/Spatial Autocorrelation Bivariate Moran's I}

3.1 Conduct correlation analysis to determine relationship between the Building Permits Index and the Census Index

(Is Correlation $R^{\wedge} 2>=0.5$ ? If Yes, continue to Activity 3.5. If No, continue to Activities $3.2-3.5$ )

3.2 (ArcMap) Conduct multiple Geographically Weighted Regression (GWR) analyses to identify Gentrification Hotspots (specific Block Groups that are gentrifying). This study used the settings/inputs bel:

Dependent Variable: Census Index

Explanatory Variable: Building Permits Index

Kernel type: Adaptive

Bandwidth Method: Bandwidth Parameter

Distance: N/A

Number of Neighbors: 10, 20, and 30

Output Cell Size: N/A

Prediction Locations/Explanatory Variables: N/A

3.3 (Optional Analysis GeoDA) Conduct Bivariate Moran's I Analysis to visually supplement/validate the results of the GWR analysis. This study used the settings/inputs below:

Contiguity Weight: Queen

Distance Weight

Transformation: Standardize (Z)

Distance Metric: Euclidean

Method

K-Nearest Neighbors, Number of Neighbors: 10, 20, and 30

Independent Variable: Building Permits Index

Dependent Variable: Census Index

3.4 Evaluate the results of the GWR analyses and Bivariate Moran's I. Compare the identified Hotspots to sources of independent validation (this study utilized local media sources, but field visits, social media or other sources could be leveraged)

3.5 Add both indices to create a final Composite Gentrification Index. Census Gentrification Index + Building Permits Gentrification Index. Standardize Index value for each Block Group from 0 to 1 (Max-X/Max-Min, where $\mathrm{X}$ is the index value for each Block Group) 
Figure 1a: AHP Model "A Novel Gentrification Index (Census Indicators and Building Permits)"

A Novel Gentrification Index: Analysis Process Model Pt.2 (Census Data and Building Permits)

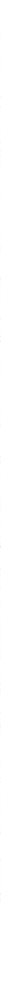




\section{Results}

Following the general activity steps presents in the APM, the results for critical outputs of the analysis are presented below (and in the Appendices):

6.1 Census Indicators Change Analysis and Index

6.1.1 Census Indicators Change Analysis

6.1.2 Census Indicators Index

6.2 Building Permits Index

6.3 Block Group Exclusions

6.4 Correlation and Spatial Analysis

6.5 Media Validation

\subsection{Census Indicators Change Analysis and Index}

\subsubsection{Census Indicators Change Analysis}

To explore overall change this study determined percent change for the selected Census Indicators, ensuring to account for inflation for any monetary based indicators (Median Household Income, Median Value, and Median Rent). Inflation was computed at 1.05 between 2013 and 2017 (US Bureau of Labor Statistics, 2019). Percent Change was calculated as:

Percent Change $=((5$ YR.ACS2017 - 5YR.ACS2013*1.05)/ 5YR.ACS2013*1.05) $)$

Table A-1 in appendix A present the descriptive statistics, percent change, and correlation for the chosen indicators both before and after Block Group exclusions.

\subsection{Census Indicators Index}

The Census Indicators index is presented in Table 4 below. Selected indicators and chosen weights were based on gentrification studies assessed in the literature review, authors local knowledge of building codes, and expected association with the gentrification process in Washington D.C. To streamline the AHP weights computations a publicly available AHP template from SCB Associates Ltd was utilized (SCB Associates, 2016), consult Appendix A Figure A-1 for AHP details. 


\begin{tabular}{|c|c|c|c|}
\hline \multicolumn{4}{|c|}{ Table 4: Census Indicators Index } \\
\hline $\begin{array}{c}\text { AHP } \\
\text { Weight }\end{array}$ & Indicator Name & Computations & Justification \\
\hline 0.294 & $\begin{array}{l}\text { Median } \\
\text { Household } \\
\text { Income in the } \\
\text { past } 12 \text { months } \\
\text { (dollars) }\end{array}$ & $\begin{array}{l}\text { CPI Inflation } \\
\text { Adjustment }\end{array}$ & $\begin{array}{l}\text { A gold standard in Gentrification Literature. Indicative of } \\
\text { Higher Income residents moving in to gentrify the } \\
\text { neighborhood. }\end{array}$ \\
\hline 0.168 & $\begin{array}{l}\text { Median Home } \\
\text { Value (dollars) }\end{array}$ & $\begin{array}{l}\text { CPI Inflation } \\
\text { Adjustment }\end{array}$ & $\begin{array}{l}\text { Gentrification Literature and expected/associated } \\
\text { changes. Increase in Home Values. }\end{array}$ \\
\hline 0.168 & $\begin{array}{l}\text { Median Rent } \\
\text { (dollars) }\end{array}$ & $\begin{array}{l}\text { CPI Inflation } \\
\text { Adjustment } \\
\text { Mean of (Gross } \\
\text { Rent+Contract Rent) }\end{array}$ & $\begin{array}{l}\text { Gentrification Literature and expected/associated } \\
\text { changes. Increase in Rent due to a more } \\
\text { attractive/desirable neighborhood and higher home } \\
\text { values. }\end{array}$ \\
\hline 0.098 & $\begin{array}{l}\text { Median Year } \\
\text { Structure Built }\end{array}$ & None & $\begin{array}{l}\text { Gentrification Literature and expected/associated } \\
\text { changes. Developers will look to invest in building New } \\
\text { Structures as they notice the area is attracting higher } \\
\text { income residents. The median year of structures built } \\
\text { across the Block Group is calculated based on the } \\
\text { original year built, and renovating will not increase } \\
\text { overall Median Year Structure Built. }\end{array}$ \\
\hline 0.098 & $\begin{array}{l}\text { Units in } \\
\text { Structure } \\
\text { Combined } \\
\text { (1attached to } \\
\text { 19) }\end{array}$ & $\begin{array}{l}\text { Combined Units in } \\
\text { Structure } 1 \text { through } 19\end{array}$ & $\begin{array}{l}\text { Unique to Washington D.C Building Codes. SFHs, } \\
\text { townhomes, or apartment buildings are remodeled to } \\
\text { have extra or hidden units to accommodate an influx of } \\
\text { new residents drawn to the area. This choice of structure } \\
\text { type aligns with many of the housing units in Washington } \\
\text { D.C }\end{array}$ \\
\hline 0.064 & $\begin{array}{l}\text { Tenure Total } \\
\text { Owner } \\
\text { Occupied }\end{array}$ & None & $\begin{array}{l}\text { Gentrification Literature. New/Incoming Residents are } \\
\text { more comfortable in owning or investing in a home in the } \\
\text { gentrifying area. }\end{array}$ \\
\hline 0.046 & HUs Estimate & None & $\begin{array}{l}\text { General Number of HUs increases as the } \\
\text { neighborhood/Block Groups becomes more desirable. } \\
\text { Most compact smaller HUs within the same area. }\end{array}$ \\
\hline 0.035 & Vacant Total & None & Vacancies decrease as the area become more desirable. \\
\hline 0.028 & 2ndMorgage & $\begin{array}{l}\text { Combined Two 2nd } \\
\text { Mortgage Categories: } \\
\text { (1) "Either 2nd } \\
\text { mortgage or home } \\
\text { equity loan, not both" } \\
\text { and (2)"Both second } \\
\text { mortgage and home } \\
\text { equity loan" }\end{array}$ & $\begin{array}{l}\text { Current residents or speculators are purchasing homes } \\
\text { using a } 2 \text { nd Mortgage to profit from or invest in the } \\
\text { ongoing gentrification. }\end{array}$ \\
\hline
\end{tabular}




\subsection{Building Permits Index}

The Building Permit categories and weights were determined based on a qualitative review of each permit category. To ensure selected permit categories represent change indicative of gentrification, this study first defined each category (Appendix A Table A-4), and then analyzed the descriptions for a subset of individual permits within in it. The selection of categories and weights was heavily dependent on DCRAs data organization and reporting standards (availably of descriptions for each permit category), and on the authors associations between specific permits types and the gentrification process. To streamline the AHP weights computations a publicly available AHP template from SCB Associates Ltd was utilized (SCB Associates, 2016), consult Appendix A Figure A-1 for AHP details.

Table 5 presents the entire Building Permits Universe of selected permit categories before various exclusions and spatial processes (joins) were applied. After joining each Building Permit category to Block Groups Geography, the study created a Permit Category to Block Group Ratio, dividing the total number of permits in a joined category by total count of 2010 Housing Units (last available full survey). To view the results of the spatial joins, and the distribution of Building Permits across Block Groups please consult Appendix A Table A-3.

\begin{tabular}{|c|l|l|l|l|l|l|}
\hline \multicolumn{7}{|c|}{ Table 5: Building Permits Index } \\
\hline $\begin{array}{c}\text { AHP } \\
\text { Weight }\end{array}$ & \multicolumn{1}{|c|}{ Indicator } & $\begin{array}{l}\text { Computati } \\
\text { ons/Transf } \\
\text { ormations }\end{array}$ & $\begin{array}{c}\text { Total } \\
\text { Count }\end{array}$ & Total Value & $\begin{array}{c}\text { Mean } \\
\text { Value/Pe } \\
\text { rmit } \\
\text { Categor } \\
\text { y }\end{array}$ & $\begin{array}{c}\text { Median } \\
\text { Value/Per } \\
\text { mit } \\
\text { Category }\end{array}$ \\
\hline 0.312 & $\begin{array}{l}\text { Addition/Addition, } \\
\text { Alteration, and } \\
\text { Repair/Alteration } \\
\text { and Repair }\end{array}$ & $\begin{array}{l}\text { Combined } \\
\text { "Addition", } \\
\text { "Addition } \\
\text { Alteration } \\
\text { Repair", } \\
\text { and } \\
\text { "Alteration } \\
\text { and } \\
\text { Repair" }\end{array}$ & 52,933 & $\$ 347,853,392$ & $\$ 6,572$ & $\$ 384$ \\
\hline 0.178 & $\begin{array}{l}\text { Electric/Electric } \\
\text { General/Electric } \\
\text { Heavy Up }\end{array}$ & $\begin{array}{l}\text { Combined } \\
\text { "Electricity } \\
\text { ", } \\
\text { "Electricity } \\
\text { General", } \\
\text { and } \\
\text { "Electricity } \\
\text { Heavy Up" }\end{array}$ & 13,927 & $\$ 239,659,464$ & $\$ 17,208$ & $\$ 84$ \\
\hline
\end{tabular}




\begin{tabular}{|c|c|c|c|c|c|c|}
\hline 0.178 & $\begin{array}{l}\text { Plumbing/Plumbin } \\
\text { g and Gas }\end{array}$ & $\begin{array}{l}\text { Combined } \\
\text { "Plumbing } \\
\text { " and } \\
\text { "Plumbing } \\
\text { and Gas" }\end{array}$ & 12,368 & $\$ 230,131,481$ & $\$ 18,607$ & $\$ 114$ \\
\hline 0.108 & Raze & None & 583 & $\$ 214,532,530$ & $\$ 367,980$ & $\$ 701$ \\
\hline 0.073 & New Building & None & 2,466 & $\$ 23,352,104$ & $\$ 9,470$ & $\$ 929$ \\
\hline 0.053 & Demolition & None & 3,596 & $\$ 3,461,399$ & $\$ 963$ & $\$ 185$ \\
\hline 0.04 & Mechanical & None & 5,574 & $\$ 987,426$ & $\$ 177$ & $\$ 51$ \\
\hline 0.032 & $\begin{array}{l}\text { Certificate of } \\
\text { Occupancy }\end{array}$ & None & 4,243 & $\$ 603,533$ & $\$ 142$ & $\$ 83$ \\
\hline 0.026 & $\begin{array}{l}\text { Building (any } \\
\text { construction that } \\
\text { impacts public space } \\
\text { and requires an extra } \\
\text { separate public } \\
\text { space permit issued } \\
\text { by the District } \\
\text { Department of } \\
\text { Transportation, see } \\
\text { Appendix Table A-4 } \\
\text { for more details) }\end{array}$ & None & 12,514 & $\$ 449,977$ & $\$ 36$ & $\$ 36$ \\
\hline \multicolumn{3}{|c|}{ Total } & 108,204 & $\$ 1,061,031,305$ & $\$ 46,795$ & $\$ 114$ \\
\hline
\end{tabular}




\subsection{Block Group Exclusions}

There were three types of exclusions conducted to ensure the appropriate Block Groups were being analyzed for gentrification:

1. Where the Median Household (HH) Income for the 5-Year ACS 2013 is one Standard Deviation above the Mean rounded to the nearest thousand $(\$ 130,000)$. Already affluent Block Groups areas are not eligible to gentrify. A total of 63 Block Groups excluded.

2. Where the Coefficient of Variation was above $40 \%$. This metric indicates the reliability and or accuracy of the collected data is too low, and that the sampling error or margin of error relative to the estimate is too large (ESRI, 2017). A total of 53 Block Groups excluded

3. Where the Median HH Income is 0. A total of 3 Block Groups excluded.

\subsection{Correlation and Spatial Analysis Results}

\subsubsection{Composite Index and GWR}

After the individual indices were computed, a correlation was calculated for the entire post exclusions study area to identify a relationship. The Significance level P-value for the entire study area was 0.024 , showing a weak relationship between the two indices for the entire study area of 331 Block Groups. The two indices were added up and standardized to create a positive Final Standardized Composite Index (FSCI) with a scale from zero to one, the map for the Composite Index is found in Figure 2. Based on the natural breaks in the FSCI values a total of 24 Block Groups were identified as gentrifying, with 7 as heavily gentrifying $(\mathrm{FSCI}>0.5)$ and 17 as nearly gentrifying(FSCI $>0.4)$. The FSCI was compromised due to the insufficient integration of local spatial factors, specifically the intensity of gentrification on a smaller scare or within neighboring Block Group clusters.

Through the application of GWR, the next phase of analysis was sensitive to the spatial fluctuations of gentrification intensity at the local Block Group level. For each individual Block Group, GWR accounted for the intensity of gentrification in a prespecified number of its nearest neighboring Block Groups. GWR identifies the correlation between the two indices, which could be among high values of both, or low values of both. It measures agreement To investigate the variance in the volume and locations of significant (gentrified or gentrifying) Block Groups, and to identify the extent of concentrations, a total of 3 GWR analyses with varying nearest neighbor parameters were executed.

For each new GWR iteration the nearest neighbor parameter was modified, testing with 10,20 , and 30 nearest neighbors. The GWR was able to efficiently detect gentrifying areas, Block Groups where there was a correlation between the index numbers (Census Indicators 
Index and Building Permits Index) and surrounded by other Block Groups with a similar relationship. A higher positive GWR regression coefficient indicates the presence of agreement between the two measures of gentrification. For a further interpretation and to create the GWR cartographic outputs below, this study relied on ESRI's guidance for interpreting GWR results (ESRI, 2020):

"There is currently no consensus on how to assess confidence in the coefficients from a GWR model. While t-tests have been used to base an inference on whether the estimated value of coefficients is significantly different than zero, the validity of this approach is still an area of active research. One approach to informally evaluate the coefficients is to divide the coefficient by the standard error provided for each feature as a way of scaling the magnitude of the estimation with the associated standard error and visualize those results, looking for clusters of high standard errors relative to their coefficients. (ESRI, 2020)"

After the recommended division, Block Groups with standardized coefficients above 0.5 were identified as gentrifying. The number of gentrifying Block Groups slightly changed with each iteration and are presented in Figures 3-6 below. There were a total of 91 gentrifying Block Groups with 10 nearest neighbors, 89 gentrifying Block Groups with 20 nearest neighbors, and 84 gentrifying Block Groups with 30 nearest neighbors

\subsubsection{Bivariate Moran's I}

An additional supplementary Bivariate Moran's I analysis was conducted in GeoDa, and through a visual comparison confirmed the general gentrifying areas identified by the GWR. The cartographic outputs and the results of the Bivariate Moran's I are presented in Figure 4.

In order to account for the continuous gradual nature of the indices, and the possible temporal lag between the physical gentrification of the built environment and associated demographic changes, this study was mindful in assigning each index to a dependent or an independent variable. The Building Permits Index was selected as the independent variable, and the Census Index as the dependent variable, with the aim of assessing and illustrating how physical build environment change precedes demographic changes. The parameters utilized for the analysis included a Queen contiguity weight and a Euclidean distance metric. Similar to the GWR analysis, 3 nearest neighbor iterations were conducted including testing with 10, 20, and 30 nearest neighbors. The Bivariate Moran's I revealed the metrics on gentrifying block groups presented in Table 6. Block groups that were classified into the High-High and High-Low categories were extracted for intersect analysis and validation against media identified Neighborhood Clusters. 


\begin{tabular}{|c|c|c|c|c|}
\hline \multicolumn{5}{|c|}{ Table 6: Moran's I Results } \\
\hline $\begin{array}{c}\text { Nearest } \\
\text { Neighbors }\end{array}$ & $\begin{array}{c}\text { Significant } \\
\text { Block Groups }\end{array}$ & $\mathbf{P}=\mathbf{0 . 0 5}$ & $\mathbf{P}=\mathbf{0 . 0 1}$ & $\mathbf{P}=\mathbf{0 . 0 0 1}$ \\
\hline \multirow{3}{*}{10} & 54 & 35 & 15 & 4 \\
\hline & High-High & Low-Low & Low-High & High Low \\
\hline & 10 & 31 & 10 & 3 \\
\hline $\begin{array}{l}\text { Nearest } \\
\text { Neighbors }\end{array}$ & $\begin{array}{l}\text { Significant } \\
\text { Block Groups }\end{array}$ & $\mathbf{P}=\mathbf{0 . 0 5}$ & $\mathbf{P}=\mathbf{0 . 0 1}$ & $\mathbf{P}=\mathbf{0 . 0 0 1}$ \\
\hline \multirow{3}{*}{20} & 40 & 32 & 8 & 0 \\
\hline & High-High & Low-Low & Low-High & High Low \\
\hline & 9 & 19 & 6 & 6 \\
\hline $\begin{array}{c}\text { Nearest } \\
\text { Neighbors }\end{array}$ & $\begin{array}{l}\text { Significant } \\
\text { Block Groups }\end{array}$ & $P=0.05$ & $\mathbf{P}=0.01$ & $P=0.001$ \\
\hline \multirow{3}{*}{30} & 78 & 45 & 28 & 5 \\
\hline & High-High & Low-Low & Low-High & High Low \\
\hline & 16 & 45 & 15 & 2 \\
\hline
\end{tabular}


Figure 3: Final Standardized Composite Index (Census Indicators and Building Permits

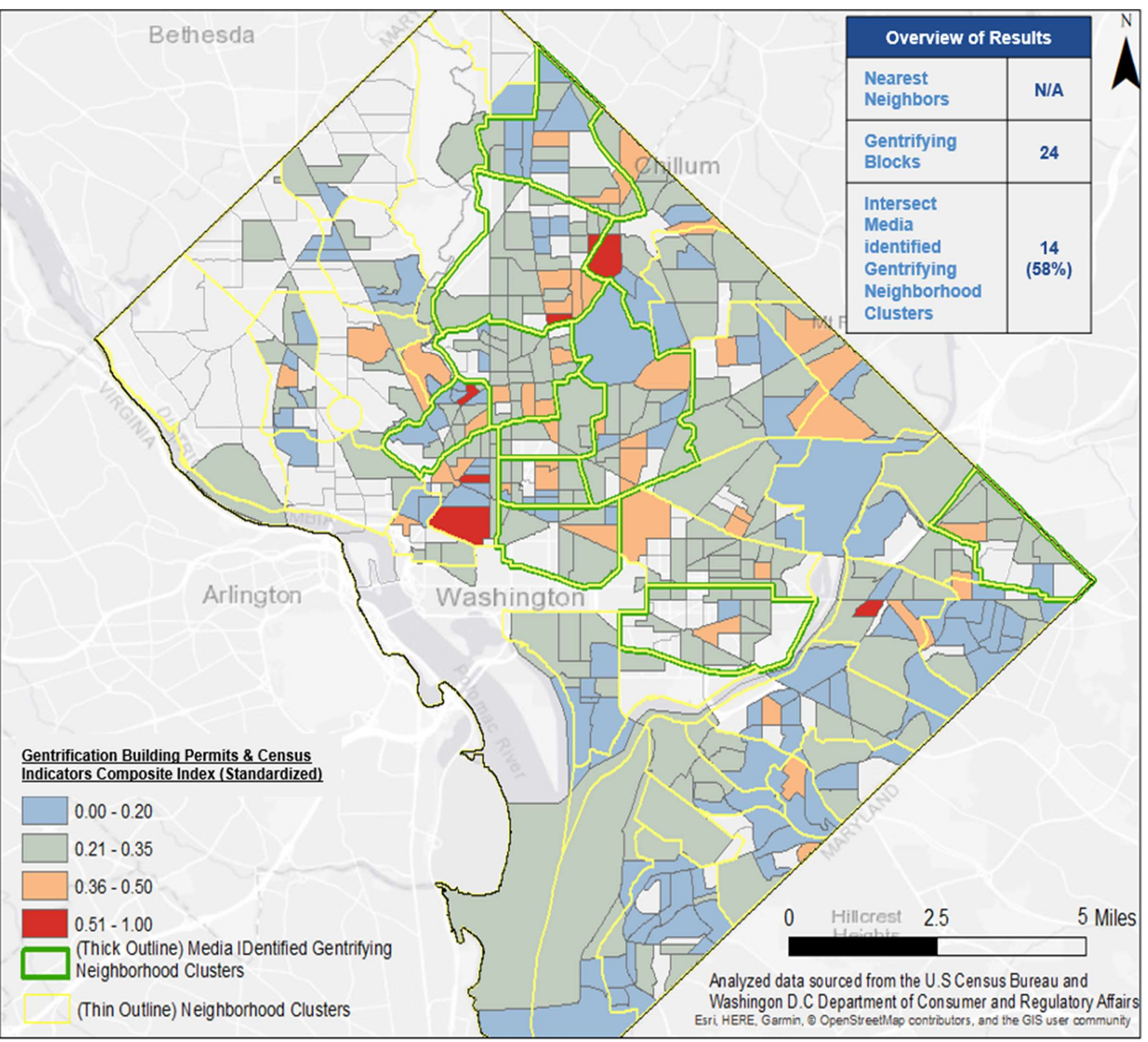


Figure 4: GWR Output with 10 Nearest Neighbor Parameter

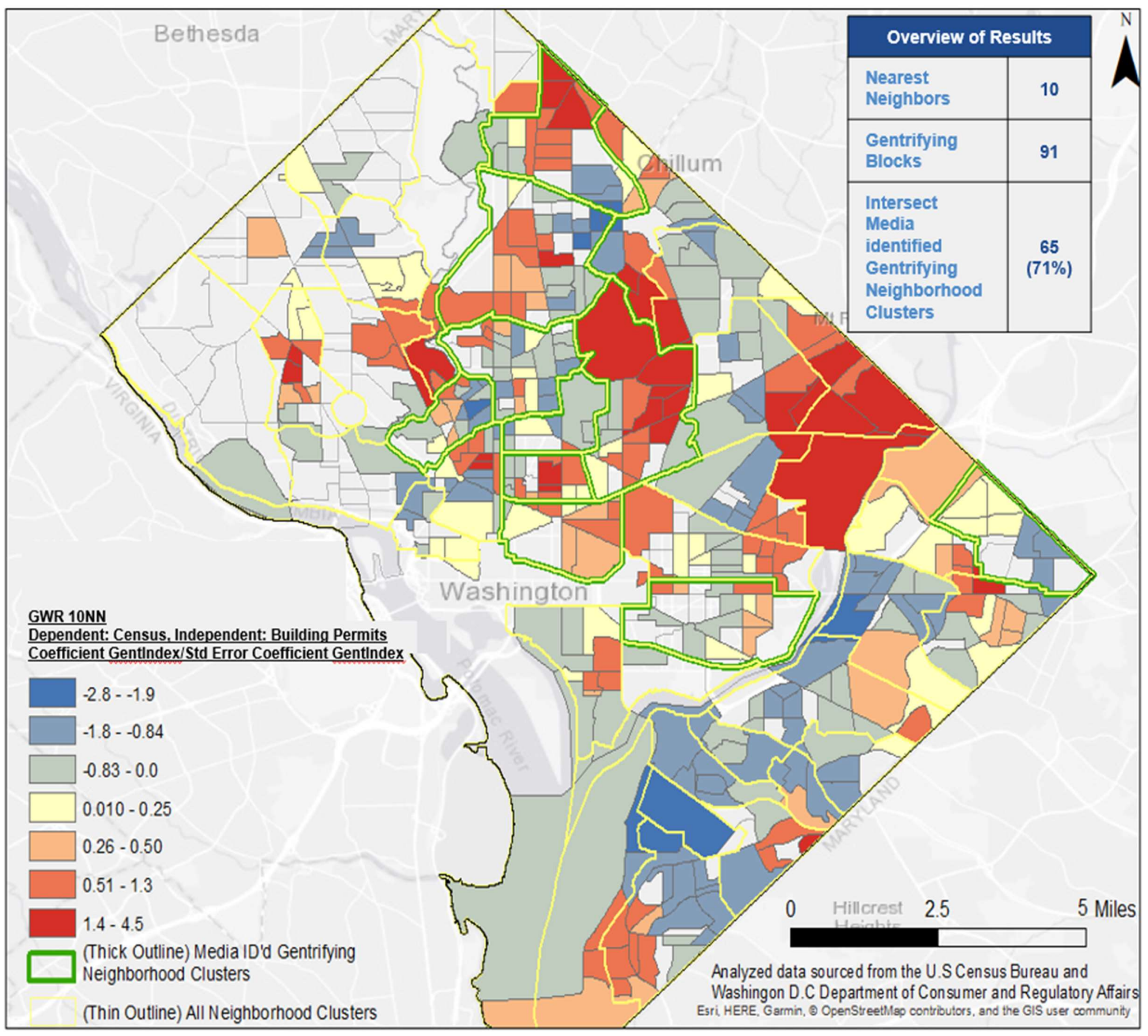


Figure 5: GWR Output with 20 Nearest Neighbor Parameter

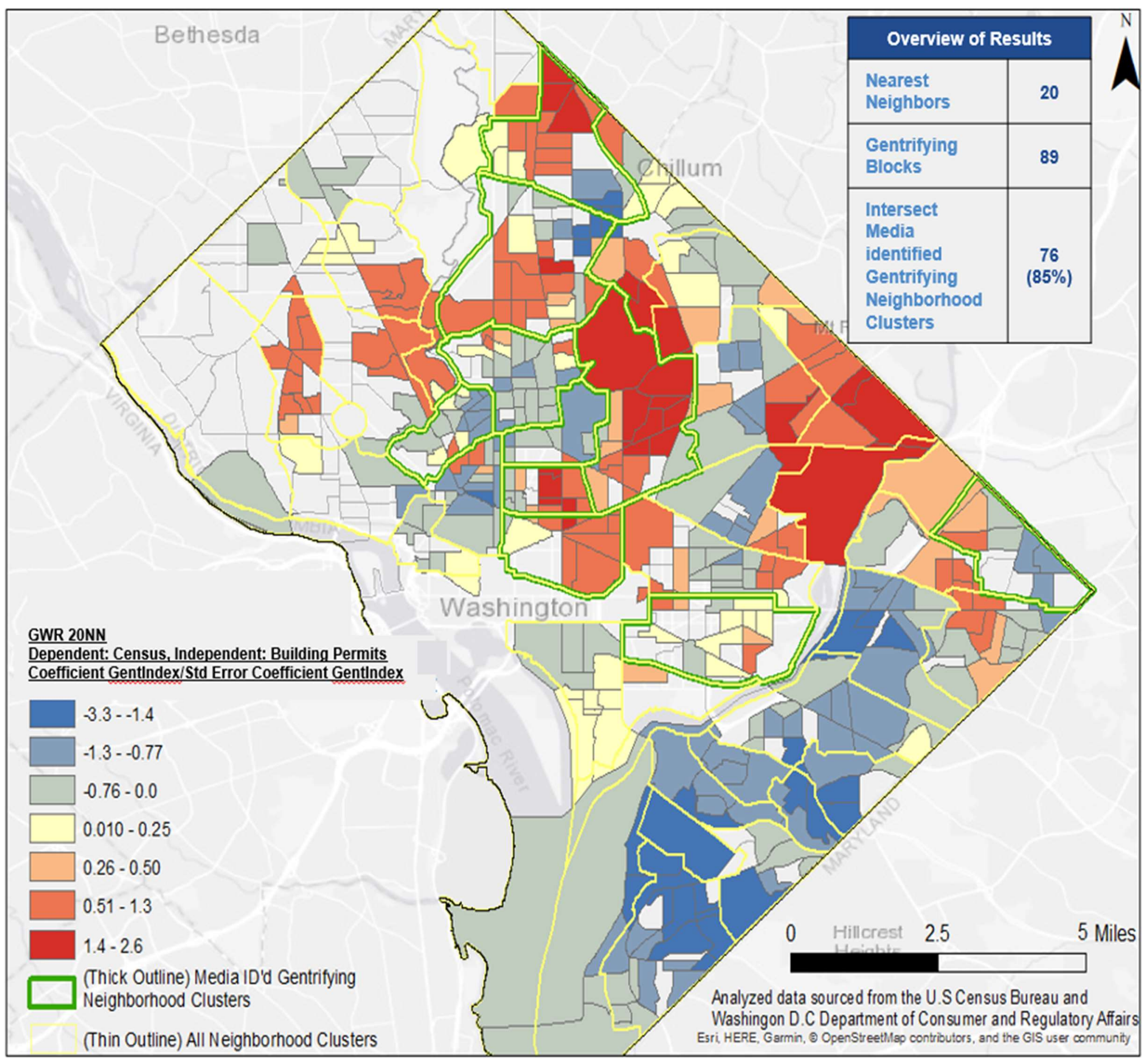


Figure 6: GWR Output with 30 Nearest Neighbor Parameter

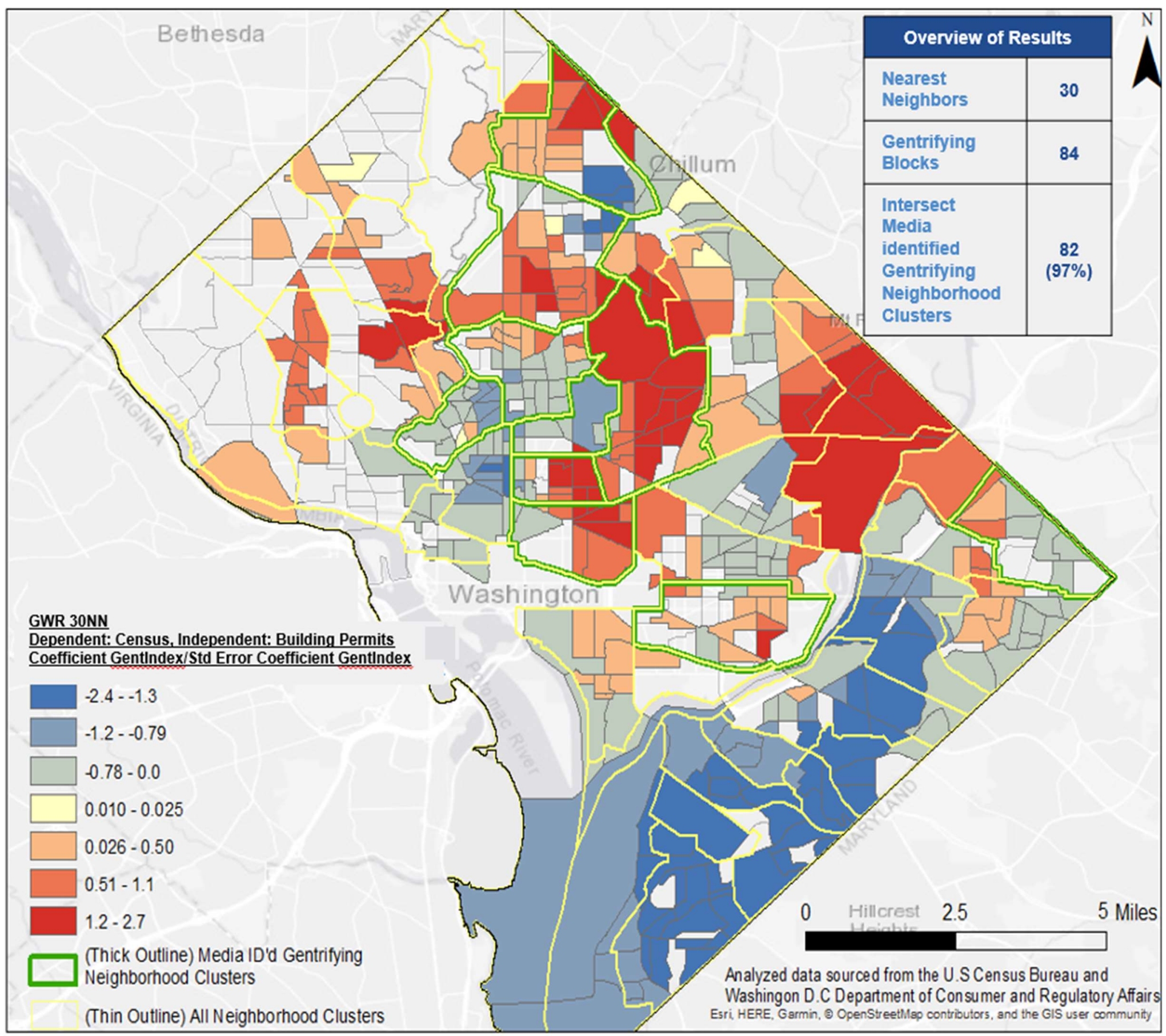


Figure 8: GeoDa Bivariate Moran's I "HotSpots"/"ColdSpots" Output (Left to Right: 10NN, 20NN, 30NN)

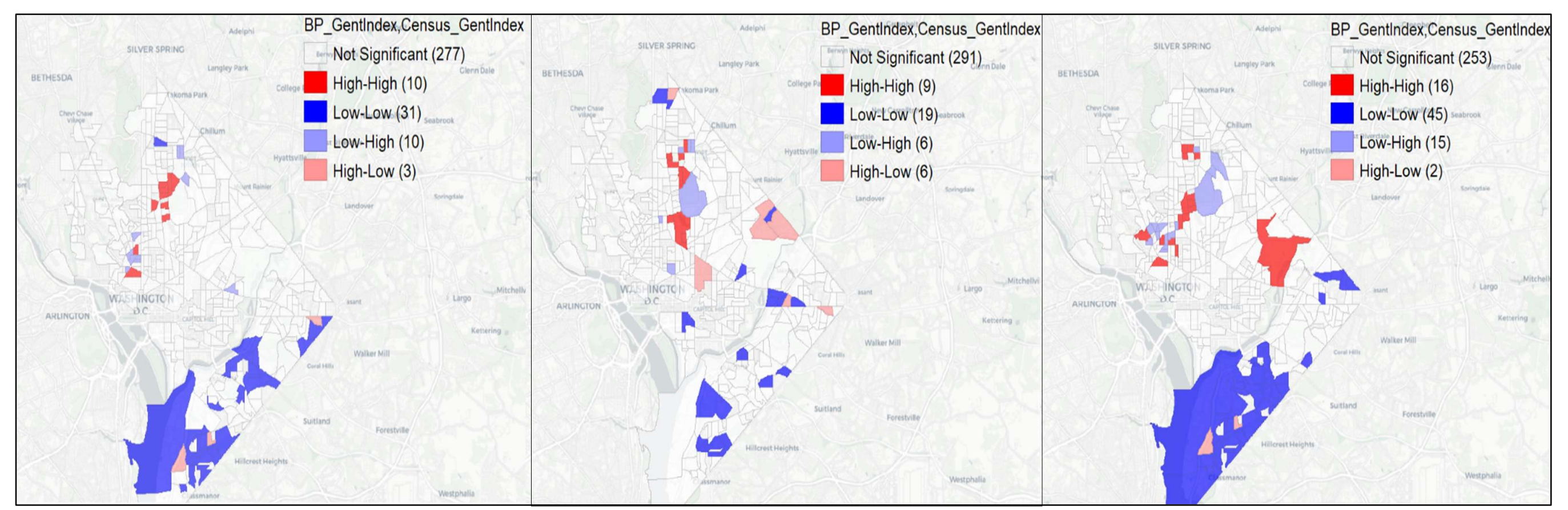




\subsection{Media Validation}

This study analyzed 39 articles from various news sources reporting on gentrification in Washington D.C (table of news sources and extracted neighborhoods can be found in Appendix B). The frequency a media source identified a gentrifying neighborhood was allocated to the geographic boundaries of that neighborhood's associated "neighborhood cluster" feature. The location, names, and number of media references for each Neighbored Cluster is displayed in Figure 8. In Table 6 and Table 7 below the gentrifying Blocks Groups identified by the study were joined to the Neighborhood Clusters. With each iteration of the GWR and with each iteration of the Bivariate Moran's I, an ever-increasing count of intersections between study identified gentrifying Block Groups and media identified gentrifying Neighborhood Clusters was observed.

Table 7: Media Validation of GWR Outputs

\begin{tabular}{|c|c|c|c|c|c|c|c|}
\hline $\begin{array}{l}\text { Neighborhood } \\
\text { Cluster Name }\end{array}$ & $\begin{array}{c}\text { Media } \\
\text { References }\end{array}$ & $\begin{array}{l}\text { Gentrifying } \\
\text { GWR 10NN } \\
\text { Block Groups: } \\
\text { Intersect } \\
\text { Count }\end{array}$ & $\begin{array}{c}\text { Gentrifying } \\
\text { GWR } \\
\text { 20NN Block } \\
\text { Groups: } \\
\text { Intersect } \\
\text { Count }\end{array}$ & $\begin{array}{c}\text { Gentrifying } \\
\text { GWR } \\
\text { 30NN Block } \\
\text { Groups } \\
\text { Intersect } \\
\text { Count: }\end{array}$ & $\begin{array}{c}\text { Gentrifying } \\
\text { GWR } \\
\text { 10NN Block } \\
\text { Groups } \\
\text { Average of } \\
\text { Coefficient } \\
\text { Ratio for } \\
\text { intersects: }\end{array}$ & $\begin{array}{c}\text { Gentrifying } \\
\text { GWR } \\
\text { 20NN Block } \\
\text { Groups } \\
\text { Average of } \\
\text { Coefficient } \\
\text { Ratio for } \\
\text { intersects: }\end{array}$ & $\begin{array}{c}\text { Gentrifying } \\
\text { GWR } \\
\text { 30NN Block } \\
\text { Groups } \\
\text { Average of } \\
\text { Coefficient } \\
\text { Ratio for } \\
\text { intersects: }\end{array}$ \\
\hline $\begin{array}{l}\text { Brightwood } \\
\text { Park, } \\
\text { Crestwood, } \\
\text { Petworth }\end{array}$ & 2 & 10 & 14 & 16 & 0.93 & 0.88 & 0.95 \\
\hline $\begin{array}{l}\text { Capitol Hill, } \\
\text { Lincoln Park }\end{array}$ & 2 & 2 & 2 & 3 & 0.60 & 0.73 & 0.79 \\
\hline $\begin{array}{l}\text { Columbia } \\
\text { Heights, Mt. } \\
\text { Pleasant, } \\
\text { Pleasant Plains, } \\
\text { Park View }\end{array}$ & 5 & 9 & 7 & 8 & 0.80 & 0.87 & 1.03 \\
\hline $\begin{array}{l}\text { Deanwood, } \\
\text { Burrville, } \\
\text { Grant Park, } \\
\text { Lincoln } \\
\text { Heights, } \\
\text { Fairmont } \\
\text { Heights }\end{array}$ & 3 & 1 & 2 & 2 & 1.43 & 0.94 & 0.56 \\
\hline $\begin{array}{l}\text { Downtown, } \\
\text { Chinatown, } \\
\text { Penn Quarters, } \\
\text { Mount Vernon }\end{array}$ & 3 & 6 & 9 & 10 & 0.84 & 0.92 & 1.03 \\
\hline
\end{tabular}




\begin{tabular}{|c|c|c|c|c|c|c|c|}
\hline $\begin{array}{l}\text { Square, North } \\
\text { Capitol Street }\end{array}$ & & & & & & & \\
\hline $\begin{array}{l}\text { Edgewood, } \\
\text { Bloomingdale, } \\
\text { Truxton Circle, } \\
\text { Eckington }\end{array}$ & 3 & 14 & 19 & 23 & 1.32 & 1.31 & 1.40 \\
\hline $\begin{array}{l}\text { Howard } \\
\text { University, Le } \\
\text { Droit Park, } \\
\text { Cardozo/Shaw }\end{array}$ & 7 & 3 & 3 & 6 & 1.02 & 1.77 & 1.35 \\
\hline $\begin{array}{l}\text { Kalorama } \\
\text { Heights, } \\
\text { Adams } \\
\text { Morgan, Lanier } \\
\text { Heights }\end{array}$ & 1 & 3 & 3 & 0 & 0.85 & 0.77 & 0.00 \\
\hline $\begin{array}{l}\text { Shaw, Logan } \\
\text { Circle }\end{array}$ & 7 & 8 & 7 & 8 & 0.94 & 1.37 & 1.21 \\
\hline $\begin{array}{l}\text { Takoma, } \\
\text { Brightwood, } \\
\text { Manor Park }\end{array}$ & 3 & 9 & 10 & 6 & 1.18 & 1.01 & 1.02 \\
\hline $\begin{array}{l}\text { Grand Total } \\
\text { (percent of } \\
\text { total } \\
\text { Gentrifying } \\
\text { Blocks } \\
\text { intersect) }\end{array}$ & 36 & $\begin{array}{l}65 / 91 \\
(71 \%)\end{array}$ & $\begin{array}{c}76 / 89 \\
(85 \%)\end{array}$ & $\begin{array}{l}82 / 84 \\
(97 \%)\end{array}$ & N/A & N/A & $\mathbf{N} / \mathbf{A}$ \\
\hline
\end{tabular}

Table 8: Media Validation of Bivariate Moran's I Outputs

\begin{tabular}{|c|c|c|c|c|c|c|c|}
\hline $\begin{array}{l}\text { Neighborhood } \\
\text { Cluster Name }\end{array}$ & $\begin{array}{c}\text { Media } \\
\text { References }\end{array}$ & $\begin{array}{c}\text { Gentrifying } \\
\text { Moran's I } \\
\text { 10NN Block } \\
\text { Groups: } \\
\text { Intersect } \\
\text { Count } \\
\end{array}$ & $\begin{array}{c}\text { Gentrifying } \\
\text { Moran's I } \\
\text { 10NN Block } \\
\text { Groups: } \\
\text { High } \\
\text { Category } \\
\end{array}$ & $\begin{array}{l}\text { Gentrifying } \\
\text { Moran's I } \\
\text { 20NN Block } \\
\text { Groups: } \\
\text { Intersect } \\
\text { Count } \\
\end{array}$ & $\begin{array}{l}\text { Gentrifying } \\
\text { Moran's I } \\
\text { 20NN Block } \\
\text { Groups: } \\
\text { High } \\
\text { Category } \\
\end{array}$ & $\begin{array}{c}\text { Gentrifying } \\
\text { Moran's I } \\
\text { 30NN Block } \\
\text { Groups: } \\
\text { Intersect } \\
\text { Count } \\
\end{array}$ & $\begin{array}{l}\text { Gentrifying } \\
\text { Moran's I } \\
\text { 30NN Block } \\
\text { Groups: } \\
\text { High } \\
\text { Category } \\
\end{array}$ \\
\hline $\begin{array}{l}\text { Brightwood } \\
\text { Park, } \\
\text { Crestwood, } \\
\text { Petworth }\end{array}$ & 2 & 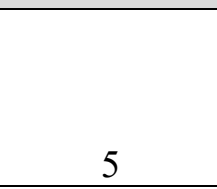 & 5 High-High & 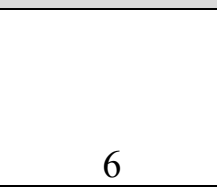 & 6 High-High & 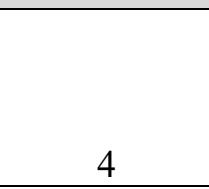 & 4 High-High \\
\hline $\begin{array}{l}\text { Capitol Hill, } \\
\text { Lincoln Park }\end{array}$ & 2 & 0 & 0 & 0 & 0 & 0 & $\begin{array}{lll}0 & 0\end{array}$ \\
\hline $\begin{array}{l}\text { Columbia } \\
\text { Heights, Mt. } \\
\text { Pleasant, } \\
\text { Pleasant Plains, } \\
\text { Park View }\end{array}$ & 5 & 3 & 3 High-High & 1 & 1 High-High & 6 & 6 High-High \\
\hline
\end{tabular}




\begin{tabular}{|c|c|c|c|c|c|c|c|}
\hline $\begin{array}{l}\text { Deanwood, } \\
\text { Burrville, } \\
\text { Grant Park, } \\
\text { Lincoln } \\
\text { Heights, } \\
\text { Fairmont } \\
\text { Heights } \\
\end{array}$ & 3 & 0 & 0 & 0 & 0 & 0 & 0 \\
\hline $\begin{array}{l}\text { Downtown, } \\
\text { Chinatown, } \\
\text { Penn Quarters, } \\
\text { Mount Vernon } \\
\text { Square, North } \\
\text { Capitol Street }\end{array}$ & 3 & 0 & 0 & 0 & 0 & 0 & 0 \\
\hline $\begin{array}{l}\text { Edgewood, } \\
\text { Bloomingdale, } \\
\text { Truxton Circle, } \\
\text { Eckington }\end{array}$ & 3 & 0 & 0 & 0 & 0 & 0 & 0 \\
\hline $\begin{array}{l}\text { Howard } \\
\text { University, Le } \\
\text { Droit Park, } \\
\text { Cardozo/Shaw }\end{array}$ & 7 & 0 & 0 & 2 & 2 High-High & 1 & 1 High-High \\
\hline $\begin{array}{l}\text { Kalorama } \\
\text { Heights, } \\
\text { Adams } \\
\text { Morgan, Lanier } \\
\text { Heights }\end{array}$ & 1 & 0 & 0 & 0 & 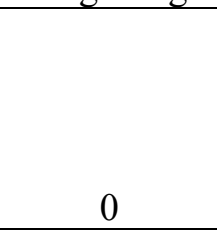 & 1 & 1 High-High \\
\hline $\begin{array}{l}\text { Shaw, Logan } \\
\text { Circle }\end{array}$ & 7 & 0 & 0 & 0 & 0 & 1 & 1 High-High \\
\hline $\begin{array}{l}\text { Takoma, } \\
\text { Brightwood, } \\
\text { Manor Park }\end{array}$ & 3 & 0 & 0 & 1 & 1 High-low & 0 & 0 \\
\hline $\begin{array}{l}\text { Grand Total } \\
\text { (percent of } \\
\text { total } \\
\text { Gentrifying } \\
\text { Blocks } \\
\text { intersect) }\end{array}$ & 36 & $\begin{array}{c}8 / 13 \\
(62 \%) \\
\end{array}$ & $\begin{array}{c}8 \text { High- } \\
\text { High }\end{array}$ & $\begin{array}{l}10 / 15 \\
(67 \%) \\
\end{array}$ & $\begin{array}{c}8 \text { High- } \\
\text { High } \\
1 \text { High-Low }\end{array}$ & $\begin{array}{c}13 / 18 \\
(72 \%)\end{array}$ & $\begin{array}{l}10 \text { High- } \\
\text { High }\end{array}$ \\
\hline
\end{tabular}


Figure 9: Media Reported Gentrification Associated to Neighborhood Clusters Overlay with GWR 30NN Gentrifying Block Groups

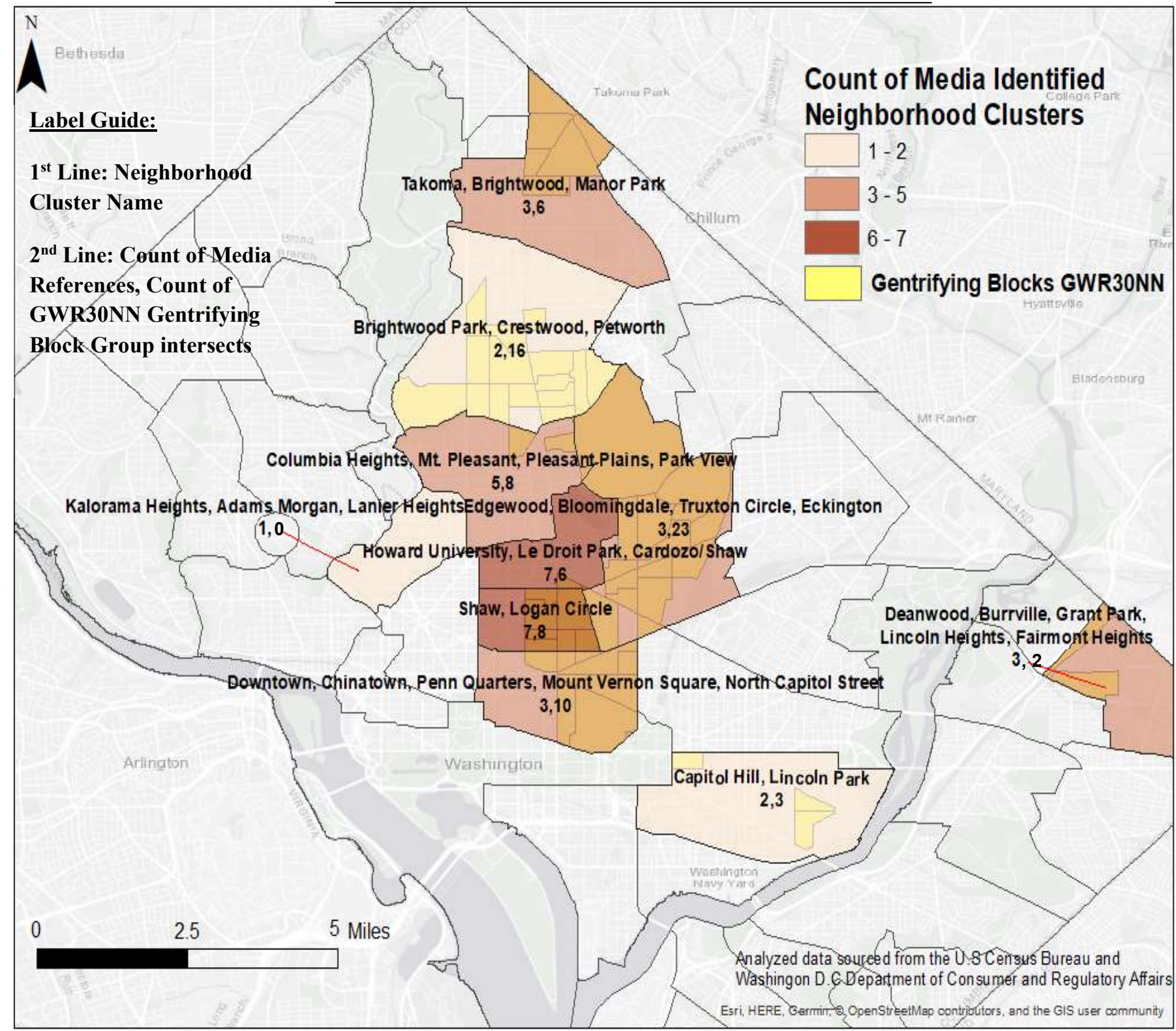




\section{Discussions and Conclusion}

\subsection{Discussion}

Although the correlation between the Census Indicators Index and the Building Permits Index for the entire study area was weak, the application of GIS analysis allowed this study to detect local concentrations of gentrifying Block Groups. To ascertain the overall success of the proposed analysis methods, and to determine the accuracy of validating through an assessment of media reports, a return to the core objective and the two main research questions presented earlier is required.

$\underline{\text { Core Objective: }}$

Do Building Permits data provide an accurate fine spatial resolution assessment of the distribution and intensity of gentrification in a large urban center?

The author believes that the core objective has been mostly achieved. The integration of Building Permits data offers a distinct spatial attribute that accounts for the fine scale with a drilldown to the individual buildings/addresses. Building Permits provide a unique input by reporting on physical housing conditions that the Census is unable to track, detect, or document. The utilization of GWR to identify gentrifying areas based on the relationship between the individual Census and Building Permit Indexes (at the Block Group level) transcends some of the limits of Census data and provides a more accurate fine spatial assessment of gentrification intensity. A positive sign for the gentrification measuring utility of permits data can be observed in the large number of intersects between the Block Groups designated as GWR gentrifying and media identified gentrifying Neighborhood Clusters (GWR 10NN:65/91 (71\%), GWR20NN:76/89 (85\%), and GWR30NN:82/84 (97\%)). The results of the Bivariate Moran's I had a similar intersect trend as the GWR analysis, with each iteration of nearest neighbor parameter seeing a higher number of intersects with the media identified gentrifying Neighborhood Clusters (Bivariate Moran's I 10NN:8/13 (62\%), Bivariate Moran's I 20NN:10/15 (67\%), and Bivariate Moran's I 30NN:13/18 (72\%)).

The validation of the GWR and Bivariate Moran's I cartographic outputs through an assessment of media sources provided a cogent yet not a foolproof method for confirming the accuracy of this studies' approach. As the number of nearest neighbors for the GWR analysis increased, the number of gentrifying Block Groups decreased. This decrease can be attributed to the expanded spatial computation window, with a higher number of neighbors, there is a smoothing effect that results in fewer GWR-identified gentrifying Block Groups. The Bivariate Moran's I had a slightly different result, as number of nearest neighbors for the Bivariate Moran's I analysis increased, the number of gentrifying Block Groups increased. This can be 
attributed to the computational nature of the analysis, and the lack of the smoothing effect observed in the GWR.

Although there were fewer gentrifying Block Groups with each increased nearest neighbor GWR parameter, it was observed that a higher percentage of GWR-identified gentrifying Blocks Groups intersected the media-identified gentrifying Neighborhood Clusters. Although the number of gentrifying Block Group identified by the Bivariate Moran's I analysis grew with each increased nearest neighbor parameter, the study observed a similar trend to the GWR intersects, with a higher percentage of Bivariate Moran's I-identified gentrifying Blocks Groups intersecting the media-identified gentrifying Neighborhood Clusters. A larger number of intersects can be interpreted to be a positive affirmation of the gentrification intensity, or as the spatial side effect of the GWR smoothing process or the increased Moran's I spatial analysis extent. It can also be the interpreted as a validation weakness in terms of a scale limitation for the Neighborhood Clusters, and a display of the inherent reductionism in transposing qualitative location rich media reports to official administrative Neighborhood Cluster units (that encompass multiple Block Groups).

\section{Main Research Questions:}

1. Do detailed Building Permits data, provide an accurate large-scale assessment of the spatial distribution, and intensity of gentrification in Washington D.C?

Building Permits data provides a large-scale component unavailable in Census Data. Anchoring the address-based data from the building permits to the closet smallest administrative boundary feature provides a level of precision for analyzing distribution and intensity that is limited in Census data. Validating the assessment quality through media analysis provides a systematic methodology to determine accuracy, but is somewhat limited by scale. For future research, the incorporation of field visits to the most intensely gentrifying areas could resolve or reduce the scale limitations observed in the media sources.

2. Does the Washington D.C case study demonstrate that Building Permits data, combined with traditional Census modes of measurement, provide an enhancement in the measurement of gentrification?

The addition of permits data reveals fine scale gentrification processes (improvement, enhancement, and revitalization of the built environment at the address level) that the Census is unable to track. The integration of building/address level permit data enhances the GWR analysis at a higher Block Groups scale to which Census data is already attached. Building Permits associated or related to the gentrification process are an ideal complement to Census Data and may reveal the presence of gentrification when Census Indicators are insignificant. Washington's modern tracking, documentation, and data sharing policies were essential in making the 
extensive DCRA Building Permits data available for analysis. The extensive media coverage of Washington D.C gentrification presented a sound validation source that may be limited for smaller cities.

\subsection{Conclusion}

The selection of Washington D.C as a case study, and the availability of the critical data for the analysis, allowed this study to accomplish its core objective and to conduct analysis that spanned a protracted temporal period. The author's local knowledge and understanding of housing architecture, building codes, and transient population characteristics were indispensable in helping guide the selection of variables for both the Census Indicators and Building Permits.

The selections of variables for each individual index is the phase of the analysis where the most researcher bias could be introduced, especially for selecting Building Permits where literature consensus is still somewhat limited. This is also the phase where future studies replicating the presented methodology could diverge in the selection of Census Indicators and Building Permits, and where accounting for unique local elements in different study areas could result in distinct study original compositions of indicators and permits (complementing local building codes, unique topographical or physical characteristics, endemic population dynamics, and other elements exclusive to a specific city or study area).

Future work and optimization would focus on the automation of various analysis phases and closer integration between spatial analysis approaches. Automating the data acquisition, data cleanup, data QC and collation, and individual index creation (variable combination and weights creation) should result in the ability to execute a higher number of variations in the composition of the final composite index and any associated GWR and Moran's I analyses. Python could be used, not only for the automation of data acquisition, cleanup, organization, and computation of indices, but also for automating spatial analysis and repetitive geoprocessing tasks such as the GWR and Moran's I. The ultimate enhancement would be the integration of the Google Street View ML analysis developed by IIlic et al.(2018), with an ideal association between the address for a Building Permit, its Street View image change library, appropriate Census data (scale and indicator variables), and any neighborhood associated media coverage. 


\section{Appendix A - Tables and Figures}

Table1 presents the statistics and change for the study area, before and after Block Group exclusions were conducted.

\section{Table A-1: Census Indicators Change from ACS2013 to ACS2017 (Pre and Post Exclusions)}

\section{Pre-Exclusions:}

\begin{tabular}{|c|c|c|c|c|c|}
\hline \multicolumn{2}{|c|}{$\begin{array}{l}\text { All } 450 \text { Block Groups: } \\
\text { ACS } 2013 \text { Estimate }\end{array}$} & \multicolumn{2}{|c|}{$\begin{array}{l}\text { All } 450 \text { Block Groups: } \\
\text { ACS } 2017 \text { Estimate }\end{array}$} & \multicolumn{2}{|c|}{$\begin{array}{l}\text { All } 450 \text { Block Groups: } \\
\text { Percent Change }\end{array}$} \\
\hline $\begin{array}{l}\text { Average of ACS13 } \\
\text { Median household } \\
\text { income in the past } 12 \\
\text { months (in } 2013 \\
\text { inflation-adjusted } \\
\text { dollars) }\end{array}$ & $\$ 80,117$ & $\begin{array}{l}\text { Average of } \\
\text { ACS17 Median } \\
\text { household income } \\
\text { in the past } 12 \\
\text { months (in } 2017 \\
\text { inflation-adjusted } \\
\text { dollars) }\end{array}$ & $\$ 87,145$ & $\begin{array}{l}\text { Percent Change } \\
\text { Average of Median } \\
\text { household income in } \\
\text { the past } 12 \text { months } \\
\text { (in } 2017 \text { inflation- } \\
\text { adjusted dollars) }\end{array}$ & $8.77 \%$ \\
\hline $\begin{array}{l}\text { StdDev of ACS13 } \\
\text { Median household } \\
\text { income in the past } 12 \\
\text { months (in } 2013 \\
\text { inflation-adjusted } \\
\text { dollars) }\end{array}$ & $\$ 49,723$ & $\begin{array}{l}\text { StdDev of ACS17 } \\
\text { Median household } \\
\text { income in the past } \\
12 \text { months (in } \\
2017 \text { inflation- } \\
\text { adjusted dollars) }\end{array}$ & $\$ 54,886$ & $\begin{array}{l}\text { Percent Change } \\
\text { StdDev of Median } \\
\text { household income in } \\
\text { the past } 12 \text { months } \\
\text { (in } 2017 \text { inflation- } \\
\text { adjusted dollars) }\end{array}$ & $10.38 \%$ \\
\hline $\begin{array}{l}\text { Median of ACS13 } \\
\text { Median household } \\
\text { income in the past } \\
12 \text { months(in } 2013 \\
\text { inflation adjusted } \\
\text { dollars) }\end{array}$ & $\$ 71,049$ & $\begin{array}{l}\text { Median of ACS17 } \\
\text { Median HH } \\
\text { Income in the past } \\
\text { 12months (in } 2017 \\
\text { inflation adjusted } \\
\text { dollars) }\end{array}$ & $\$ 80,976$ & $\begin{array}{l}\text { Percent Change } \\
\text { Median of HH } \\
\text { Income in the past } \\
\text { 12months (in } 2017 \\
\text { inflation adjusted } \\
\text { dollars) }\end{array}$ & $13.97 \%$ \\
\hline $\begin{array}{l}\text { Sum of ACS13 } \\
\text { Estimate_HUs }\end{array}$ & 298,327 & $\begin{array}{l}\text { Sum of } \\
\text { ACS17_Estimate_ } \\
\text { HUs }\end{array}$ & 308,161 & $\begin{array}{l}\text { Percent Change, } \\
\text { Sum of HU }\end{array}$ & $3.30 \%$ \\
\hline $\begin{array}{l}\text { Average of } \\
\text { ACS13_Estimate_HU } \\
\mathrm{s}\end{array}$ & 663 & $\begin{array}{l}\text { Average of } \\
\text { ACS17 HUs }\end{array}$ & 685 & $\begin{array}{l}\text { Percent Change, } \\
\text { Average of HUs }\end{array}$ & $3.30 \%$ \\
\hline $\begin{array}{l}\text { Sum of ACS13 Vacant } \\
\text { Total }\end{array}$ & 34,678 & $\begin{array}{l}\text { Sum of ACS17 } \\
\text { Vacant Total }\end{array}$ & 30,176 & $\begin{array}{l}\text { Percent Change, } \\
\text { Sum of Vacant } \\
\text { Total: }\end{array}$ & $-12.98 \%$ \\
\hline $\begin{array}{l}\text { Average of ACS13 } \\
\text { Vacant }\end{array}$ & 77 & $\begin{array}{l}\text { Average of } \\
\text { ACS17 Vacant }\end{array}$ & 67 & $\begin{array}{l}\text { Percent Change, } \\
\text { Average of Vacant }\end{array}$ & $-12.98 \%$ \\
\hline
\end{tabular}




\begin{tabular}{|c|c|c|c|c|c|}
\hline $\begin{array}{l}\text { Sum of ACS13;Tenure } \\
\text { Total: - Owner } \\
\text { occupied }\end{array}$ & 111,070 & $\begin{array}{l}\text { Sum of } \\
\text { ACS17;Tenure } \\
\text { Total: - Owner } \\
\text { occupied }\end{array}$ & 115,795 & $\begin{array}{l}\text { Percent Change, } \\
\text { Tenure Total: - } \\
\text { Owner occupied }\end{array}$ & $4.25 \%$ \\
\hline $\begin{array}{l}\text { Average of ACS13; } \\
\text { Tenure Total: - Owner } \\
\text { occupied }\end{array}$ & 247 & $\begin{array}{l}\text { Average of } \\
\text { ACS17; Tenure } \\
\text { Total: - Owner } \\
\text { occupied }\end{array}$ & 257 & $\begin{array}{l}\text { Percent Change, } \\
\text { Average of Tenure } \\
\text { Total: - Owner } \\
\text { occupied }\end{array}$ & $4.25 \%$ \\
\hline $\begin{array}{l}\text { Sum of } \\
\text { ACS13_UnitsinStruct } \\
\text { ureCombined(1attache } \\
\text { dto19) }\end{array}$ & 159,296 & $\begin{array}{l}\text { Sum of } \\
\text { ACS17_UnitsinStr } \\
\text { uctureCombined(1 } \\
\text { attachedto19) }\end{array}$ & 162,229 & $\begin{array}{l}\text { Percent Change, } \\
\text { Sum of Units in } \\
\text { Structure } \\
\text { Combined(1 attached } \\
\text { to19) }\end{array}$ & $1.84 \%$ \\
\hline $\begin{array}{l}\text { Average of ACS13 } \\
\text { Units in Structure } \\
\text { Combined(1 lattachedto } \\
\text { 19) }\end{array}$ & 354 & $\begin{array}{l}\text { Average of } \\
\text { ACS17__Units in } \\
\text { Structure } \\
\text { Combined(1attach } \\
\text { edto19) }\end{array}$ & 361 & $\begin{array}{l}\text { Percent Change, } \\
\text { Average of Units in } \\
\text { Structure } \\
\text { Combined(1 attached } \\
\text { to19) }\end{array}$ & $1.84 \%$ \\
\hline $\begin{array}{l}\text { Average of ACS13 } \\
\text { Median year structure } \\
\text { built }\end{array}$ & 1929 & $\begin{array}{l}\text { Average of } \\
\text { ACS17_Median } \\
\text { year structure built }\end{array}$ & 1944 & $\begin{array}{l}\text { Percent Change, } \\
\text { Average of Median } \\
\text { year structure built }\end{array}$ & $0.77 \%$ \\
\hline $\begin{array}{l}\text { Median_of_ACS13 } \\
\text { Median_year structure } \\
\text { built }\end{array}$ & 1946 & $\begin{array}{l}\text { Median_ACS17 } \\
\text { Median year } \\
\text { structure built }\end{array}$ & 1948 & $\begin{array}{l}\text { Percent Change, } \\
\text { Median YEAR } \\
\text { Structure Built }\end{array}$ & $0.10 \%$ \\
\hline $\begin{array}{l}\text { Average of } \\
\text { ACS13_Median Rent }\end{array}$ & $\$ 1,203$ & $\begin{array}{l}\text { Average of } \\
\text { ACS17_Median } \\
\text { Rent }\end{array}$ & $\$ 1,368$ & $\begin{array}{l}\text { Percent Change, } \\
\text { Average of } \\
\text { MEDIAN_RENT }\end{array}$ & $13.67 \%$ \\
\hline $\begin{array}{l}\text { Median of ACS13 } \\
\text { Median Rent }\end{array}$ & $\$ 1,125$ & $\begin{array}{l}\text { Median of } \\
\text { ACS17_Median } \\
\text { Rent }\end{array}$ & $\$ 1,295$ & $\begin{array}{l}\text { Percent Change, } \\
\text { Median of Median } \\
\text { Rent }\end{array}$ & $15.05 \%$ \\
\hline $\begin{array}{l}\text { Average of } \\
\text { ACS13_Estimate; } \\
\text { Median Housing value } \\
\text { (dollars) }\end{array}$ & $\$ 469,673$ & $\begin{array}{l}\text { Average of } \\
\text { ACS17_Estimate; } \\
\text { Median Housing } \\
\text { value (dollars) }\end{array}$ & $\$ 523,462$ & $\begin{array}{l}\text { Percent Change, } \\
\text { Average of } \\
\text { ACS17_Estimate; } \\
\text { Median Housing } \\
\text { value (dollars) }\end{array}$ & $11.45 \%$ \\
\hline $\begin{array}{l}\text { Median of ACS13 } \\
\text { Median Housing value } \\
\text { (dollars) }\end{array}$ & $\$ 412,176$ & $\begin{array}{l}\text { Median of } \\
\text { ACS17_Median } \\
\text { Housing value } \\
\text { (dollars) }\end{array}$ & $\$ 470,300$ & $\begin{array}{l}\text { Percent Change, } \\
\text { Median of ACS17_ } \\
\text { Median Housing } \\
\text { value (dollars) }\end{array}$ & $14.10 \%$ \\
\hline $\begin{array}{l}\text { Sum of ACS13_2 } 2^{\text {nd }} \\
\text { Mortgage }\end{array}$ & 20,794 & $\begin{array}{l}\text { Sum of } \\
\text { ACS17_2 } \\
\text { Mortgage }\end{array}$ & 16,083 & $\begin{array}{l}\text { Percent Change, } \\
\text { Sum of ACS17_2 } \\
\text { Mortgage }\end{array}$ & $-22.66 \%$ \\
\hline $\begin{array}{l}\text { Average of } \\
\text { ACS13_2 } 2^{\text {nd }} \text { Mortgage }\end{array}$ & 46 & $\begin{array}{l}\text { Average of } \\
\text { ACS17_2 } \\
\text { Mortgage }\end{array}$ & 36 & $\begin{array}{l}\text { Percent Change, } \\
\text { Average of } \\
\text { ACS17_2nd } \\
\text { Mortgage }\end{array}$ & $-22.66 \%$ \\
\hline
\end{tabular}




\begin{tabular}{|l|l|l|l|l|l|}
$\begin{array}{l}\text { Median of ACS13_2 } \\
\text { Mortgage }\end{array}$ & 37 & $\begin{array}{l}\text { Median of } \\
\text { ACS17_2 } \\
\text { Mortgage }\end{array}$ & 30 & $\begin{array}{l}\text { Percent Change, } \\
\text { Median of } \\
\text { ACS17_2 } \\
\text { Mortgage }\end{array}$ & $-18.92 \%$ \\
\hline
\end{tabular}

\section{Post Exclusions:}

\begin{tabular}{|c|c|c|c|c|c|c|}
\hline \multicolumn{2}{|c|}{$\begin{array}{l}\text { Post Exclusions } 331 \\
\text { Block Groups: ACS } 2013\end{array}$} & \multicolumn{2}{|c|}{$\begin{array}{c}\text { Post Exclusions } 331 \\
\text { Block Groups: ACS } 2017\end{array}$} & \multicolumn{2}{|c|}{$\begin{array}{l}\text { Post Exclusions } 331 \text { Block } \\
\text { Groups: Percent Change }\end{array}$} & $\begin{array}{l}\text { Difference } \\
(450-331)\end{array}$ \\
\hline $\begin{array}{l}\text { Average of } \\
\text { ACS13 } \\
\text { Median } \\
\text { household } \\
\text { income in } \\
\text { the past } 12 \\
\text { months (in } \\
2013 \\
\text { inflation- } \\
\text { adjusted } \\
\text { dollars) }\end{array}$ & $\$ 67,269$ & $\begin{array}{l}\text { Average } \\
\text { of ACS17 } \\
\text { Median } \\
\text { household } \\
\text { income in } \\
\text { the past } \\
12 \text { months } \\
\text { (in } 2017 \\
\text { inflation- } \\
\text { adjusted } \\
\text { dollars) }\end{array}$ & $\$ 74,292$ & $\begin{array}{l}\text { Average of } \\
\text { ACS17_Est } \\
\text { imate; } \\
\text { Median } \\
\text { household } \\
\text { income in } \\
\text { the past } 12 \\
\text { months (in } \\
2017 \\
\text { inflation- } \\
\text { adjusted } \\
\text { dollars) }\end{array}$ & $10.44 \%$ & $1.67 \%$ \\
\hline $\begin{array}{l}\text { StdDev of } \\
\text { ACS13 } \\
\text { Median } \\
\text { household } \\
\text { income in } \\
\text { the past } 12 \\
\text { months (in } \\
2013 \\
\text { inflation- } \\
\text { adjusted } \\
\text { dollars) }\end{array}$ & $\$ 30,249$ & $\begin{array}{l}\text { StdDev of } \\
\text { ACS17 } \\
\text { Median } \\
\text { household } \\
\text { income in } \\
\text { the past } \\
12 \text { months } \\
\text { (in } 2017 \\
\text { inflation- } \\
\text { adjusted } \\
\text { dollars) }\end{array}$ & $\$ 41,108$ & $\begin{array}{l}\text { StdDev of } \\
\text { ACS17_Est } \\
\text { imate; } \\
\text { Median } \\
\text { household } \\
\text { income in } \\
\text { the past } 12 \\
\text { months (in } \\
2017 \\
\text { inflation- } \\
\text { adjusted } \\
\text { dollars) }\end{array}$ & $35.90 \%$ & $25.52 \%$ \\
\hline $\begin{array}{l}\text { Median of } \\
\text { ACS13 } \\
\text { Median } \\
\text { household } \\
\text { income in } \\
\text { the past } \\
12 \text { months(i } \\
\text { n } 2013 \\
\text { inflation } \\
\text { adjusted } \\
\text { dollars) }\end{array}$ & $\$ 64,654$ & $\begin{array}{l}\text { Median of } \\
\text { ACS17 } \\
\text { Median } \\
\text { HH } \\
\text { Income in } \\
\text { the past } \\
12 \text { months } \\
\text { (in } 2017 \\
\text { inflation } \\
\text { adjusted } \\
\text { dollars) }\end{array}$ & $\$ 72,031$ & $\begin{array}{l}\text { Median of } \\
\text { ACS17_Est } \\
\text { imate:Medi } \\
\text { an HH } \\
\text { Income in } \\
\text { the past } \\
\text { 12months } \\
\text { (in } 2017 \\
\text { inflation } \\
\text { adjusted } \\
\text { dollars) }\end{array}$ & $11.41 \%$ & $-2.56 \%$ \\
\hline $\begin{array}{l}\text { Sum of } \\
\text { ACS13 } \\
\text { Estimate_- } \\
\text { HUs }\end{array}$ & 239,294 & $\begin{array}{l}\text { Sum of } \\
\text { ACS17_E } \\
\text { stimate_H } \\
\text { Us }\end{array}$ & 246,111 & $\begin{array}{l}\text { Sum of } \\
\text { ACS17_Est } \\
\text { imate_HUs } \\
\text {; Total }\end{array}$ & $2.85 \%$ & $-0.45 \%$ \\
\hline
\end{tabular}




\begin{tabular}{|c|c|c|c|c|c|c|}
\hline $\begin{array}{l}\text { Average of } \\
\text { ACS13_Es } \\
\text { timate_HU } \\
\text { s }\end{array}$ & 723 & $\begin{array}{l}\text { Average } \\
\text { of ACS17 } \\
\text { HUs }\end{array}$ & 744 & $\begin{array}{l}\text { Average of } \\
\text { ACS17_Est } \\
\text { imate_HUs } \\
\text {; Total }\end{array}$ & $2.85 \%$ & $-0.45 \%$ \\
\hline $\begin{array}{l}\text { Sum of } \\
\text { ACS13 } \\
\text { Vacant } \\
\text { Total }\end{array}$ & 27,832 & $\begin{array}{l}\text { Sum of } \\
\text { ACS17 } \\
\text { Vacant } \\
\text { Total }\end{array}$ & 23,381 & $\begin{array}{l}\text { Sum of } \\
\text { ACS17_Est } \\
\text { imate;Vaca } \\
\text { nt Total: }\end{array}$ & $-15.99 \%$ & $-3.01 \%$ \\
\hline $\begin{array}{l}\text { Average of } \\
\text { ACS13 } \\
\text { Vacant }\end{array}$ & 84 & $\begin{array}{l}\text { Average } \\
\text { of ACS17 } \\
\text { Vacant }\end{array}$ & 71 & $\begin{array}{l}\text { Average of } \\
\text { ACS17_Est } \\
\text { imate;Vaca } \\
\text { nt Total: }\end{array}$ & $-15.99 \%$ & $-3.01 \%$ \\
\hline $\begin{array}{l}\text { Sum of } \\
\text { ACS13;Te } \\
\text { nure Total: } \\
\text { - Owner } \\
\text { occupied }\end{array}$ & 80,478 & $\begin{array}{l}\text { Sum of } \\
\text { ACS17;Te } \\
\text { nure } \\
\text { Total: - } \\
\text { Owner } \\
\text { occupied }\end{array}$ & 84,873 & $\begin{array}{l}\text { Sum of } \\
\text { ACS17_Est } \\
\text { imate;Tenu } \\
\text { re Total: - } \\
\text { Owner } \\
\text { occupied }\end{array}$ & $5.46 \%$ & $1.21 \%$ \\
\hline $\begin{array}{l}\text { Average of } \\
\text { ACS13; } \\
\text { Tenure } \\
\text { Total: - } \\
\text { Owner } \\
\text { occupied }\end{array}$ & 243 & $\begin{array}{l}\text { Average } \\
\text { of ACS17; } \\
\text { Tenure } \\
\text { Total: - } \\
\text { Owner } \\
\text { occupied } \\
\end{array}$ & 256 & $\begin{array}{l}\text { Average of } \\
\text { ACS17_Est } \\
\text { imate;Tenu } \\
\text { re Total: - } \\
\text { Owner } \\
\text { occupied }\end{array}$ & $5.46 \%$ & $1.21 \%$ \\
\hline $\begin{array}{l}\text { Sum of } \\
\text { ACS13_U } \\
\text { nitsinStruct } \\
\text { ureCombin } \\
\text { ed(1attache } \\
\text { dto19) }\end{array}$ & 128,882 & $\begin{array}{l}\text { Sum of } \\
\text { ACS17_U } \\
\text { nitsinStru } \\
\text { ctureCom } \\
\text { bined(1att } \\
\text { achedto19 } \\
\text { ) }\end{array}$ & 130,982 & $\begin{array}{l}\text { Sum of } \\
\text { ACS17_Un } \\
\text { itsinStructu } \\
\text { reCombine } \\
\text { d(1attached } \\
\text { to19) }\end{array}$ & $1.63 \%$ & $-0.21 \%$ \\
\hline $\begin{array}{l}\text { Average of } \\
\text { ACS13 } \\
\text { Units in } \\
\text { Structure } \\
\text { Combined( } \\
\text { 1attachedto } \\
\text { 19) }\end{array}$ & 389 & $\begin{array}{l}\text { Average } \\
\text { of } \\
\text { ACS17 } \\
\text { Units in } \\
\text { Structure } \\
\text { Combined } \\
\text { (1attached } \\
\text { to19) }\end{array}$ & 396 & $\begin{array}{l}\text { Average of } \\
\text { ACS17_Un } \\
\text { itsinStructu } \\
\text { reCombine } \\
\text { d(1attached } \\
\text { to19) }\end{array}$ & $1.63 \%$ & $-0.21 \%$ \\
\hline $\begin{array}{l}\text { Average of } \\
\text { ACS13 } \\
\text { Median } \\
\text { year } \\
\text { structure } \\
\text { built }\end{array}$ & 1940 & $\begin{array}{l}\begin{array}{l}\text { Average } \\
\text { of }\end{array} \\
\text { ACS17_- } \\
\text { Median } \\
\text { year } \\
\text { structure } \\
\text { built }\end{array}$ & 1954 & $\begin{array}{l}\text { Average of } \\
\text { ACS17_Est } \\
\text { imate; } \\
\text { Median } \\
\text { year } \\
\text { structure } \\
\text { built }\end{array}$ & $0.68 \%$ & $-0.08 \%$ \\
\hline $\begin{array}{l}\text { Median_of } \\
\text { ACS13 } \\
\text { Median } \\
\text { year } \\
\text { structure } \\
\text { built }\end{array}$ & 1949 & $\begin{array}{l}\text { Median_A } \\
\text { CS17 } \\
\text { Median } \\
\text { year } \\
\text { structure } \\
\text { built }\end{array}$ & 1948 & $\begin{array}{l}\text { Median_A } \\
\text { CS17Medi } \\
\text { anYEAR_S } \\
\text { tructureBui } \\
\text { lt }\end{array}$ & $-0.05 \%$ & $-0.15 \%$ \\
\hline
\end{tabular}




\begin{tabular}{|c|c|c|c|c|c|c|}
\hline $\begin{array}{l}\text { Average of } \\
\text { ACS13_M } \\
\text { edian Rent }\end{array}$ & $\$ 1,207$ & $\begin{array}{l}\text { Average } \\
\text { of } \\
\text { ACS17_- } \\
\text { Median } \\
\text { Rent }\end{array}$ & $\$ 1,345$ & $\begin{array}{l}\text { Average of } \\
\text { ACS17_M } \\
\text { EDIAN_R } \\
\text { ENT }\end{array}$ & $11.44 \%$ & $-2.23 \%$ \\
\hline $\begin{array}{l}\text { Median of } \\
\text { ACS13 } \\
\text { Median } \\
\text { Rent }\end{array}$ & $\$ 1,116$ & $\begin{array}{l}\text { Median of } \\
\text { ACS17_- } \\
\text { Median } \\
\text { Rent }\end{array}$ & $\$ 1,295$ & $\begin{array}{l}\text { Median of } \\
\text { ACS17_M } \\
\text { edianRent }\end{array}$ & $15.95 \%$ & $0.89 \%$ \\
\hline $\begin{array}{l}\text { Average of } \\
\text { ACS13_Es } \\
\text { timate; } \\
\text { Median } \\
\text { Housing } \\
\text { value } \\
\text { (dollars) }\end{array}$ & $\$ 409,178$ & $\begin{array}{l}\text { Average } \\
\text { of } \\
\text { ACS17_E } \\
\text { stimate; } \\
\text { Median } \\
\text { Housing } \\
\text { value } \\
\text { (dollars) }\end{array}$ & $\$ 447,147$ & $\begin{array}{l}\text { Average of } \\
\text { ACS17_Est } \\
\text { imate; } \\
\text { Median } \\
\text { value } \\
\text { (dollars) }\end{array}$ & $9.28 \%$ & $-2.17 \%$ \\
\hline $\begin{array}{l}\text { Median of } \\
\text { ACS13 } \\
\text { Median } \\
\text { Housing } \\
\text { value } \\
\text { (dollars) }\end{array}$ & $\$ 389,216$ & $\begin{array}{l}\text { Median of } \\
\text { ACS17_- } \\
\text { Median } \\
\text { Housing } \\
\text { value } \\
\text { (dollars) }\end{array}$ & $\$ 470,300$ & $\begin{array}{l}\text { Median of } \\
\text { ACS17_M } \\
\text { edian } \\
\text { Value } \\
\text { (dollars) }\end{array}$ & $20.83 \%$ & $6.73 \%$ \\
\hline $\begin{array}{l}\text { Sum of } \\
\text { ACS13_2 } \\
\text { Mortgage }\end{array}$ & 13,840 & $\begin{array}{l}\text { Sum of } \\
\text { ACS17_2n } \\
\text { d } \\
\text { Mortgage }\end{array}$ & 10,997 & $\begin{array}{l}\text { Sum of } \\
\text { ACS17_2n } \\
\text { dMorgage }\end{array}$ & $-20.54 \%$ & $2.11 \%$ \\
\hline $\begin{array}{l}\text { Average of } \\
\text { ACS13_2 } \\
\text { Mortgage }\end{array}$ & 42 & $\begin{array}{l}\text { Average } \\
\text { of } \\
\text { ACS17_2n } \\
\text { d } \\
\text { Mortgage }\end{array}$ & 33 & $\begin{array}{l}\text { Average of } \\
\text { ACS17_2n } \\
\text { dMorgage }\end{array}$ & $-20.54 \%$ & $2.11 \%$ \\
\hline $\begin{array}{l}\text { Median of } \\
\text { ACS13_2 } \\
\text { Mortgage }\end{array}$ & 35 & $\begin{array}{l}\text { Median of } \\
\text { ACS17_2 } \\
\text { d } \\
\text { Mortgage }\end{array}$ & 30 & $\begin{array}{l}\text { Median of } \\
\text { ACS17_2n } \\
\text { dMorgage }\end{array}$ & $-14.29 \%$ & $4.63 \%$ \\
\hline
\end{tabular}

Table A-2: Correlation between Census Indicators Percent Change

\begin{tabular}{|c|c|c|c|c|c|c|c|c|c|}
\hline $\begin{array}{c}\text { Indicator } \\
\text { Names }\end{array}$ & $\begin{array}{c}\text { PerCh_M } \\
\text { edian_HH } \\
\text { _Income_ } \\
\text { past12mos }\end{array}$ & $\begin{array}{c}\text { PerCh } \\
\text { Esti } \\
\text { mate_- } \\
\text { HUs }\end{array}$ & $\begin{array}{c}\text { PerCh_Vacan } \\
\text { t Total }\end{array}$ & $\begin{array}{c}\text { PerCh_Te } \\
\text { nure } \\
\text { Total_Ow } \\
\text { nerOcc }\end{array}$ & $\begin{array}{c}\text { PerCh_U } \\
\text { nitsinStru } \\
\text { ctureCom } \\
\text { bined(1att } \\
\text { achedto19 } \\
\text { ) }\end{array}$ & $\begin{array}{c}\text { PerCh_M } \\
\text { edian_yea } \\
\text { r_structur } \\
\text { e_built }\end{array}$ & $\begin{array}{l}\text { PerCh_M } \\
\text { edianRent }\end{array}$ & $\begin{array}{c}\text { PerCh_M } \\
\text { edianHom } \\
\text { eValue_do } \\
\text { llars }\end{array}$ & $\begin{array}{l}\text { PerCh_2n } \\
\text { dMorgage }\end{array}$ \\
\hline $\begin{array}{l}\text { PerCh_M } \\
\text { edian_HH } \\
\text { _Income_- } \\
\text { past12mos }\end{array}$ & 1.00 & & & & & & & & \\
\hline $\begin{array}{l}\text { PerCh_Es } \\
\text { timate_H } \\
\text { Us }\end{array}$ & -0.06 & 1.00 & & & & & & & \\
\hline
\end{tabular}




\begin{tabular}{|c|c|c|c|c|c|c|c|c|c|}
\hline $\begin{array}{l}\text { PerCh_Va } \\
\text { cant Total }\end{array}$ & -0.04 & 0.16 & 1.00 & & & & & & \\
\hline $\begin{array}{l}\text { PerCh_Te } \\
\text { nure } \\
\text { Total_Ow } \\
\text { nerOcc }\end{array}$ & 0.11 & 0.27 & -0.09 & 1.00 & & & & & \\
\hline $\begin{array}{l}\text { PerCh_U } \\
\text { nitsinStru } \\
\text { ctureCom } \\
\text { bined(1att } \\
\text { achedto19 } \\
\text { ) }\end{array}$ & -0.06 & 0.23 & 0.02 & 0.08 & 1.00 & & & & \\
\hline $\begin{array}{l}\text { PerCh_M } \\
\text { edian_yea } \\
\text { r_structur } \\
\text { e_built }\end{array}$ & -0.05 & 0.24 & 0.05 & -0.01 & -0.06 & 1.00 & & & \\
\hline $\begin{array}{l}\text { PerCh_M } \\
\text { edianRent }\end{array}$ & 0.29 & 0.06 & -0.10 & 0.03 & -0.01 & 0.08 & 1.00 & & \\
\hline $\begin{array}{l}\text { PerCh_M } \\
\text { edianHom } \\
\text { eValue_do } \\
\text { llars }\end{array}$ & 0.17 & 0.09 & -0.03 & 0.07 & -0.02 & 0.02 & 0.07 & 1.00 & \\
\hline $\begin{array}{l}\text { PerCh_2n } \\
\text { dMorgage }\end{array}$ & -0.02 & 0.06 & -0.01 & 0.17 & -0.01 & 0.03 & -0.05 & 0.04 & 1.00 \\
\hline
\end{tabular}

Table A-3: Building Permits Joined to Block Groups Statistics (Pre and Post Exclusions)

\begin{tabular}{|l|r|r|r|r|r|r|}
\hline \multicolumn{7}{|c|}{ Pre-Exclusion (All 450 Block Groups) } \\
\hline & \multicolumn{1}{|c|}{$\begin{array}{l}\text { Mean/ } \\
\text { Block } \\
\text { Group }\end{array}$} & $\begin{array}{c}\text { Median/ } \\
\text { Block } \\
\text { Group }\end{array}$ & Sum & $\begin{array}{c}\text { Mean/Block } \\
\text { Group }\end{array}$ & $\begin{array}{c}\text { Median/Bloc } \\
\text { k Group }\end{array}$ \\
\hline Permit Category & Sum & & & & & \\
\hline $\begin{array}{l}\text { Addition_AdditionAItera } \\
\text { tiontRepair_Alteration } \\
\text { Repair }\end{array}$ & 52,933 & 118 & 82 & $347,853,392$ & 773,008 & 99,447 \\
\hline $\begin{array}{l}\text { Electtric_ElectricGen_El } \\
\text { ectHeavyUp }\end{array}$ & 13,927 & 31 & 23 & $239,659,464$ & 532,577 & 4,413 \\
\hline Plumbing_PlumbingGas & 12,368 & 28 & 20 & $230,131,481$ & 511,403 & 5,001 \\
\hline Raze & 583 & 3 & 2 & $214,532,530$ & 476,739 & 0 \\
\hline New Building & 2,466 & 9 & 3 & $23,352,104$ & 51,894 & 1,880 \\
\hline Demolition & 3,596 & 9 & 5 & $3,461,399$ & 7,692 & 929 \\
\hline Mechanical & 5,574 & 13 & 10 & 987,426 & 2,194 & 904 \\
\hline NA.CertOccupancy & 4,243 & 11 & 6 & 603,533 & 1,341 & 535 \\
\hline Building & 12,514 & 29 & 23 & 449,977 & 1,000 & 687 \\
\hline Total & 108,204 & 251 & 174 & $1,061,031,305$ & $2,357,847$ & 113,796 \\
\hline
\end{tabular}




\section{Post-Exclusion (331 Block Groups)}

\begin{tabular}{|c|c|c|c|c|c|c|}
\hline Permit Category & Sum & $\begin{array}{l}\text { Me } \\
\text { an/ } \\
\text { Blo } \\
\text { ck } \\
\text { Gro } \\
\text { up }\end{array}$ & $\begin{array}{l}\text { Median/Blo } \\
\text { ck Group }\end{array}$ & Sum & $\begin{array}{l}\text { Mean/Block } \\
\text { Group }\end{array}$ & $\begin{array}{l}\text { Median/Block } \\
\text { Group }\end{array}$ \\
\hline $\begin{array}{l}\text { Addition_AdditionAlterationt } \\
\text { Repair_Alteration Repair }\end{array}$ & 36,202 & 110 & 77 & $310,402,028$ & 937,770 & 94,852 \\
\hline $\begin{array}{l}\text { Electtric_ElectricGen_ElectHe } \\
\text { avyUp }\end{array}$ & 10,028 & 31 & 22 & $238,386,298$ & 720,200 & 4,136 \\
\hline Plumbing_PlumbingGas & 8,762 & 27 & 18 & $229,018,369$ & 691,898 & 4,759 \\
\hline Raze & 401 & 3 & 2 & $1,813,772$ & 5,480 & 0 \\
\hline New Building & 1,959 & 10 & 3 & $17,496,663$ & 52,860 & 1,438 \\
\hline Demolition & 2,496 & 9 & 5 & $2,584,924$ & 7,809 & 832 \\
\hline Mechanical & 3,911 & 12 & 10 & 762,054 & 2,302 & 860 \\
\hline NA.CertOccupancy & 3,206 & 11 & 6 & 443,082 & 1,339 & 528 \\
\hline Building & 9,200 & 29 & 20 & 331,034 & 1,000 & 650 \\
\hline Total & 76,165 & 241 & 163 & $801,238,225$ & $2,420,659$ & 108,054 \\
\hline
\end{tabular}

\section{Raw Change Post Exclusions}

\begin{tabular}{|c|c|c|c|c|c|c|}
\hline Permit Category & Sum & $\begin{array}{l}\text { Mean/BI } \\
\text { ock } \\
\text { Group }\end{array}$ & $\begin{array}{l}\text { Media } \\
\text { n/Bloc } \\
\text { k } \\
\text { Group }\end{array}$ & Sum & $\begin{array}{l}\text { Mean/BI } \\
\text { ock } \\
\text { Group }\end{array}$ & $\begin{array}{l}\text { Median/BI } \\
\text { ock Group }\end{array}$ \\
\hline $\begin{array}{l}\text { Addition_AdditionAlterationt } \\
\text { Repair_Alteration Repair }\end{array}$ & $-16,731$ & -8 & -5 & $-37,451,364$ & 164,763 & $-4,595$ \\
\hline $\begin{array}{l}\text { Electtric_ElectricGen_ElectHe } \\
\text { avyUp }\end{array}$ & $-3,899$ & -1 & -1 & $-1,273,167$ & 187,624 & -277 \\
\hline Plumbing_PlumbingGas & $-3,606$ & -1 & -2 & $-1,113,112$ & 180,495 & -242 \\
\hline Raze & -182 & 0 & 0 & $-212,718,758$ & $-471,259$ & 0 \\
\hline New Building & -507 & 1 & 0 & $-5,855,441$ & 966 & -442 \\
\hline Demolition & $-1,100$ & 0 & 0 & $-876,474$ & 117 & -97 \\
\hline Mechanical & $-1,663$ & -1 & 0 & $-225,372$ & 108 & -44 \\
\hline NA.CertOccupancy & $-1,037$ & 0 & 0 & $-160,450$ & -3 & -7 \\
\hline Building & $-3,314$ & 0 & -3 & $-118,943$ & 0 & -37 \\
\hline Total & $-32,039$ & -10 & -11 & $-259,793,080$ & 62,812 & $-5,742$ \\
\hline
\end{tabular}


Percent Change Post Exclusion

\begin{tabular}{|l|r|r|r|l|r|r|}
\hline & Sum & $\begin{array}{l}\text { Mean/BI } \\
\text { ock } \\
\text { Group }\end{array}$ & $\begin{array}{l}\text { Median/B } \\
\text { lock } \\
\text { Group }\end{array}$ & $\begin{array}{l}\text { Sum } \\
\text { ost } \\
\text { llue }\end{array}$ & $\begin{array}{l}\text { Mean/BI } \\
\text { ock } \\
\text { Group }\end{array}$ & $\begin{array}{l}\text { Median/B } \\
\text { lock } \\
\text { Group }\end{array}$ \\
\hline $\begin{array}{l}\text { Addition_AdditionAlterationtRepa } \\
\text { ir_Alteration Repair }\end{array}$ & $-32 \%$ & $-7 \%$ & $-6 \%$ & $-11 \%$ & $21 \%$ & $-5 \%$ \\
\hline $\begin{array}{l}\text { Electtric_ElectricGen_ElectHeavy } \\
\text { Up }\end{array}$ & $-28 \%$ & $-2 \%$ & $-4 \%$ & $-1 \%$ & $35 \%$ & $-6 \%$ \\
\hline Plumbing_PlumbingGas & $-29 \%$ & $-3 \%$ & $-8 \%$ & $0 \%$ & $35 \%$ & $-5 \%$ \\
\hline Raze & $-31 \%$ & $1 \%$ & $0 \%$ & $-99 \%$ & $-99 \%$ & \#DIV/0! \\
\hline New Building & $-21 \%$ & $11 \%$ & $0 \%$ & $-25 \%$ & $2 \%$ & $-24 \%$ \\
\hline Demolition & $-31 \%$ & $-3 \%$ & $0 \%$ & $-25 \%$ & $2 \%$ & $-10 \%$ \\
\hline Mechanical & $-30 \%$ & $-4 \%$ & $0 \%$ & $-23 \%$ & $5 \%$ & $-5 \%$ \\
\hline NA.CertOccupancy & $-24 \%$ & $-2 \%$ & $0 \%$ & $-27 \%$ & $0 \%$ & $-1 \%$ \\
\hline Building & $-26 \%$ & $-1 \%$ & $-13 \%$ & $-26 \%$ & $0 \%$ & $-5 \%$ \\
\hline Total & $-30 \%$ & $-4 \%$ & $-6 \%$ & $-24 \%$ & $3 \%$ & $-5 \%$ \\
\hline
\end{tabular}

Table A-4: Building Permits Definitions (definitions from the DCRA Building Permits Portal, 2019)

\begin{tabular}{|l|l|l|}
\hline Permit Type & \multicolumn{1}{|c|}{ Definition } & Submission Requirements \\
\hline \multirow{5}{*}{$\begin{array}{l}\text { Occupancy } \\
\text { Ocutificate of }\end{array}$} & $\begin{array}{l}\text { A certificate of occupancy is needed to occupy any } \\
\text { structure other than a single-family dwelling. To } \\
\text { include the following uses: two family flat, } \\
\text { apartment house and all commercial uses. } \\
\text { (Accessory dwellings do not require a Certificate of } \\
\text { Occupancy but a Building Permit is required). } \\
\text { The main purpose of a Certificate of Occupancy is to } \\
\text { needed ensure that the use of a building, structure or } \\
\text { land in the District of Columbia conforms to the } \\
\text { Zoning Regulations (DCMR Title 11) provisions of } \\
\text { the DC Construction Codes, and the Green Building } \\
\text { Act. In most cases, no person can use a building, } \\
\text { structure or land in the District of Columbia for any } \\
\text { purpose other than a single-family dwelling, until a } \\
\text { valid Certificate of Occupancy has been issued. }\end{array}$ & $\begin{array}{l}\text { Requirements vary based on type. } \\
\text { (https://dcra.dc.gov/node/1410111) }\end{array}$ \\
\hline
\end{tabular}




\begin{tabular}{|c|c|c|}
\hline & $\begin{array}{l}\text { There are six types of Certificate of Occupancy } \\
\text { applications including } \\
\text { Ownership Change, Use Change, Occupant Load } \\
\text { Change, Revision, Temporary Occupancy, and New } \\
\text { Building }\end{array}$ & \\
\hline $\begin{array}{l}\text { ADDITION } \\
\text { (2016 OLDER) }\end{array}$ & $\begin{array}{l}\text { This type of permit is an extension or increase in the } \\
\text { building area, aggregate floor area, number of } \\
\text { stories, or height of a building or structure. }\end{array}$ & $\begin{array}{l}\text { 1) All additions (i.e. increase in } \\
\text { height or length, enclosing an } \\
\text { existing structure) must include a } \\
\text { surveyor's plat that details the } \\
\text { evaluation and dimensions of the } \\
\text { existing and proposed structures. } \\
\text { 2) If you are submitting a residential } \\
\text { addition that is less } 500 \text { square feet, } \\
\text { above grade and one level, your } \\
\text { plans can be reviewed within our } \\
\text { Homeowners Center. Please be sure } \\
\text { to provide a minimum of } 3 \text { sets of } \\
\text { plans on a minimum of } 11 \text { x } 17 \\
\text { paper. (**Please view the } \\
\text { Homeowners Center page for the } \\
\text { advantages and criteria of the } \\
\text { Homeowner's Center.) } \\
\text { 3) If work includes construction on } \\
\text { the property line or party walls, } \\
\text { neighbor notification is required }\end{array}$ \\
\hline $\begin{array}{l}\text { ADDITION } \\
\text { ALTERATION } \\
\text { REPAIR }\end{array}$ & $\begin{array}{l}\text { This type of permit is an extension or increase in the } \\
\text { building area, aggregate floor area, number of } \\
\text { stories, or height of a building or structure. }\end{array}$ & $\begin{array}{l}\text { 1) All additions (i.e. increase in } \\
\text { height or length, enclosing an } \\
\text { existing structure) must include a } \\
\text { surveyor's plat that details the } \\
\text { evaluation and dimensions of the } \\
\text { existing and proposed structures. } \\
\text { 2) If you are submitting a residential } \\
\text { addition that is less } 500 \text { square feet, } \\
\text { above grade and one level, your } \\
\text { plans can be reviewed within our } \\
\text { Homeowners Center. Please be sure } \\
\text { to provide a minimum of } 3 \text { sets of } \\
\text { plans on a minimum of } 11 \text { x } 17 \\
\text { paper. (**Please view the } \\
\text { Homeowners Center page for the } \\
\text { advantages and criteria of the } \\
\text { Homeowner's Center.) } \\
\text { 3) If work includes construction on } \\
\text { the property line or party walls, } \\
\text { neighbor notification is required }\end{array}$ \\
\hline $\begin{array}{l}\text { ALTERATION } \\
\text { AND REPAIR }\end{array}$ & $\begin{array}{l}\text { Any construction or renovation to an existing } \\
\text { structure, to include space reconfiguration, } \\
\text { replacement in kind, repairs etc. }\end{array}$ & $\begin{array}{l}\text { 1) For interior renovations such as } \\
\text { kitchen or bathroom remodeling and } \\
\text { interior renovation of an existing } \\
\text { commercial space, Alteration and } \\
\text { Repair is the appropriate permit type. } \\
\text { 2) Architectural plans are needed for } \\
\text { review and if the square footage of }\end{array}$ \\
\hline
\end{tabular}




\begin{tabular}{|c|c|c|}
\hline & & $\begin{array}{l}\text { the work area is less than } 1000 \\
\text { square feet, your project can be } \\
\text { reviewed over the counter in the } \\
\text { Permit Center. } \\
\text { 3) For projects that exceed } 1000 \\
\text { square feet, plans are reviewed in } \\
\text { electronically within ProjectDox. }\end{array}$ \\
\hline DEMOLITION & $\begin{array}{l}\text { The removal of interior and/or exterior elements, } \\
\text { systems or finishes. (Not a Raze). }\end{array}$ & $\begin{array}{l}\text { 1) Interior and exterior demolition of } \\
\text { less than } 5,000 \text { square feet, pictures } \\
\text { are required to complete the plan } \\
\text { review. (If your property is not } \\
\text { within a historic district, you can } \\
\text { apply, pay and receive a postcard } \\
\text { permit online). Please check our } \\
\text { Property Information Verification } \\
\text { System (PIVS) to confirm. } \\
\text { 2) For projects that exceed the above } \\
\text { square footage, plans will be required } \\
\text { for review along with pictures to } \\
\text { show what is existing. } \\
\text { 3) Demolition work can also be } \\
\text { included in the submission of your } \\
\text { Building Permit, depending on the } \\
\text { timeline of your project. (Please } \\
\text { ensure to detail demolition details } \\
\text { within your description of work and } \\
\text { within your drawing submittal) }\end{array}$ \\
\hline $\begin{array}{l}\text { NEW } \\
\text { BUILDING }\end{array}$ & $\begin{array}{l}\text { Construction of an entirely new structure that has not } \\
\text { been previously occupied. }\end{array}$ & $\begin{array}{l}\text { 1) Architectural plans are required } \\
\text { for plan review. A structural engineer } \\
\text { is required for structural work. } \\
\text { 2) A surveyor's plat is required for } \\
\text { review and must detail the location } \\
\text { of the new structure. }\end{array}$ \\
\hline RAZE & $\begin{array}{l}\text { This permit is required if nothing remains at the site } \\
\text { except for a party wall and/or a foundation. }\end{array}$ & $\begin{array}{l}\text { 1) Certificate of Insurance is required } \\
\text { for covering the raze contractor } \\
\text { unless the accessory } \\
\text { building/structural is } 500 \text { square feet } \\
\text { or less in area and no more than one } \\
\text { story fully detached. } \\
\text { 2) Pictures of the existing structure }\end{array}$ \\
\hline Building & $\begin{array}{l}\text { Any construction done on public space requires a } \\
\text { separate public space permit issued by the District } \\
\text { Department of Transportation. } \\
\text { A Building Permit is required for the following } \\
\text { work: } \\
\text { - Repairing a fence up to a height of } 7 \text { feet ( } 2.13 \\
\text { meters) above grade, entirely on private property and } \\
\text { behind the building restriction line. } \\
\text { - Interior demolition of non-bearing elements in a } \\
\text { space up to } 5,000 \text { square feet ( } 464.5 \text { square meters) } \\
\text { - Application of fire-retardant paint, up to } 5 \text { gallons. } \\
\text { - Installation of } 1 \text { temporary construction trailer on }\end{array}$ & N/A \\
\hline
\end{tabular}


private property.

- (Any Fireworks Permits issued after June 26, 2009

shall be deemed invalid.)

- Erection of 1 Christmas tree stand on private property.

- Renewal of an active Building Permit.

- Revision of an active permit for change of ownership or change of address.

- Repairs of existing fire escape.

-Repairs of front porch and steps in a single family dwelling.

- Repairs of rear porch and steps in a single family dwelling.

-Repairs of up to 4 stories of a single interior stairway.

- Repairs of guardrails and/or handrails in up to 4 stories of a single interior stairway.

- Repairs of guardrails of up to 5 balconies.

- Replacement in kind of guards and guardrails of up to 5 balconies and/or exterior porches on the same building. Replacement in kind, when applied to architectural features, means replacement with a feature of like material that replicates the existing feature in proportion, appearance, texture, design, detail and dimensions.

- Replacement in kind of up to 5 fire windows.

Replacement in kind, when applied to architectural features, means replacement with a feature of like material that replicates the existing feature in proportion, appearance, texture, design, detail and dimensions.

- Replacement in kind of up to 5 fire doors.

Replacement in kind, when applied to architectural features, means replacement with a feature of like material that replicates the existing feature in proportion, appearance, texture, design, detail and dimensions.

- Replacement in kind of up to 5 fire or smoke dampers. Replacement in kind, when applied to architectural features, means replacement with a feature of like material that replicates the existing feature in proportion, appearance, texture, design, detail and dimensions.

- Replacement in kind of up to 10 sprinklers, on an existing residential, commercial or industrial system. Replacement in kind, when applied to architectural features, means replacement with a feature of like material that replicates the existing feature in proportion, appearance, texture, design, detail and dimensions.

- Replacement in kind of rated suspended ceiling tile in an area up to 5,000 square feet (464.5 square meters). Replacement in kind, when applied to architectural features, means replacement with a 


\begin{tabular}{|c|c|c|}
\hline & $\begin{array}{l}\text { feature of like material that replicates the existing } \\
\text { feature in proportion, appearance, texture, design, } \\
\text { detail and dimensions. } \\
\text { - Replacement in kind of existing fence on private } \\
\text { property. Replacement in kind, when applied to } \\
\text { architectural features, means replacement with a } \\
\text { feature of like material that replicates the existing } \\
\text { feature in proportion, appearance, texture, design, } \\
\text { detail and dimensions. } \\
\text { - Replacement in kind of interior wall coverings. } \\
\text { Replacement in kind, when applied to architectural } \\
\text { features, means replacement with a feature of like } \\
\text { material that replicates the existing feature in } \\
\text { proportion, appearance, texture, design, detail and } \\
\text { dimensions. } \\
\text { - Replacement in kind of up to } 800 \text { square feet (74.3 } \\
\text { square meters) of gypsum board. Replacement in } \\
\text { kind, when applied to architectural features, means } \\
\text { replacement with a feature of like material that } \\
\text { replicates the existing feature in proportion, } \\
\text { appearance, texture, design, detail and dimensions. } \\
\text { - Replacement in kind of ductwork of a single } \\
\text { system, in non-hazardous exhaust and commercial } \\
\text { kitchen exhaust systems. Replacement in kind, when } \\
\text { applied to architectural features, means replacement } \\
\text { with a feature of like material that replicates the } \\
\text { existing feature in proportion, appearance, texture, } \\
\text { design, detail and dimensions. } \\
\text {-Replacement in kind of up to } 4 \text { stories of a single } \\
\text { interior stairway. Replacement in kind, when applied } \\
\text { to architectural features, means replacement with a } \\
\text { feature of like material that replicates the existing } \\
\text { feature in proportion, appearance, texture, design, } \\
\text { detail and dimensions. } \\
\text { - Replacement in kind of guards, guardrails and/or } \\
\text { handrails in up to } 4 \text { stories of a single interior } \\
\text { stairway. Replacement in kind, when applied to } \\
\text { architectural features, means replacement with a } \\
\text { feature of like material that replicates the existing } \\
\text { feature in proportion, appearance, texture, design, } \\
\text { detail and dimensions. }\end{array}$ & \\
\hline $\begin{array}{l}\text { Electrical - } \\
\text { General }\end{array}$ & $\begin{array}{l}\text { An electrical (general) postcard permit is required for } \\
\text { this work: } \\
\text {-Installation of not more than } 10 \text { new outlets and not } \\
\text { more than } 10 \text { new lighting fixtures for a residential, } \\
\text { commercial or industrial project. } \\
\text { - Replacement or repair of not more than } 10 \text { existing } \\
\text { outlets and not more than } 10 \text { existing lighting } \\
\text { fixtures for a residential, commercial or industrial } \\
\text { project. } \\
\text { - Installation of not more than } 10 \text { new outlets in a } \\
\text { power-limited system for a residential, commercial } \\
\text { or industrial project. }\end{array}$ & N/A \\
\hline
\end{tabular}




\begin{tabular}{|c|c|c|}
\hline & $\begin{array}{l}\text { - Installation or replacement of not more than } 1 \\
\text { residential electric appliance for a residential project. }\end{array}$ & \\
\hline $\begin{array}{l}\text { Electrical - } \\
\text { Heavy Up }\end{array}$ & $\begin{array}{l}\text { The electrical (heavy-up) postcard can be issued only } \\
\text { to licensed contractors -- to upgrade } 1 \text { existing } \\
\text { electrical system to a maximum of } 200 \text { Amps. This } \\
\text { electrical postcard permit does not authorize the } \\
\text { erection of electrical service and/or meter boxes in } \\
\text { public space. }\end{array}$ & $\mathrm{N} / \mathrm{A}$ \\
\hline Mechanical & $\begin{array}{l}\text { The mechanical postcard permit can be issued only } \\
\text { to licensed contractors for. } \\
\text {-Installation of not more than } 1 \text { new air conditioning } \\
\text { unit, up to a maximum of } 10 \text {-tons of equivalent } \\
\text { refrigerating effect. } \\
\text { - Repairs to not more than } 1 \text { existing refrigerating or } \\
\text { cooling unit, up to a maximum of } 10 \text {-tons of } \\
\text { equivalent refrigerating effect. } \\
\text { - Conversion of } 1 \text { existing refrigerating or cooling } \\
\text { unit to adapt it to use an environmentally safe } \\
\text { refrigerant in a residential, commercial or industrial } \\
\text { facility, not including the installation of rated } \\
\text { detection, alarm and ventilation devices. } \\
\text { - Installation, as required, of gas detection, alarm and } \\
\text { ventilation devices related to the use of } \\
\text { environmentally safe refrigerants as a result of the } \\
\text { conversion of existing refrigerating or cooling } \\
\text { equipment, in a single location, inside a residential, } \\
\text { commercial or industrial facility. }\end{array}$ & $\mathrm{N} / \mathrm{A}$ \\
\hline Plumbing & $\begin{array}{l}\text { The plumbing postcard permit can be issued to } \\
\text { licensed contractors only. } \\
\text { - Installation of not more than } 1 \text { new plumbing } \\
\text { fixture, on a residential, commercial or industrial } \\
\text { project. } \\
\text { - Repairs to existing plumbing systems, including the } \\
\text { installation of not more than } 1 \text { new fixture. } \\
\text { - Minor alterations to existing plumbing systems, } \\
\text { including the installation of not more than } 1 \text { new } \\
\text { fixture. Excludes changing the piping layout serving } \\
\text { more than } 3 \text { fixtures, including domestic water, } \\
\text { sewer or venting systems. } \\
\text { - Replacement of not more than } 1 \text { plumbing fixture, } \\
\text { on a residential, commercial or industrial project. } \\
\text { - Installation of } 1 \text { backflow preventer. } \\
\text { - One sewer or water line cut. } \\
\text { - Pressure testing of a single water system. }\end{array}$ & N/A \\
\hline Electrical & $\begin{array}{l}\text { Repair, replacement, or installation of an electrical } \\
\text { system (s). }\end{array}$ & N/A \\
\hline
\end{tabular}




\begin{tabular}{|l|l|l|} 
Mechanical & $\begin{array}{l}\text { Installation, repair, or replacement of a refrigeration } \\
\text { and/or air conditioning system. }\end{array}$ & N/A \\
\hline $\begin{array}{l}\text { Plumbing and } \\
\text { Gas }\end{array}$ & $\begin{array}{l}\text { Repair, replacement or installation of a plumbing or } \\
\text { gas system. }\end{array}$ & N/A \\
\hline
\end{tabular}

Figure A-1: Output of SCB AHP Template (Top Census Indicators, Bottom: Building Permits)

\begin{tabular}{|c|c|c|c|c|c|c|c|c|c|c|c|}
\hline & \multicolumn{3}{|c|}{ Median_HH_Incorr MedianHomeVal MedianRent } & \multicolumn{4}{|c|}{ Median_year_str UnitsinStructurer Tenure Total_OwEstimate_HUs } & \multirow{2}{*}{$\begin{array}{c}\text { Vacant Total } \\
6\end{array}$} & \multirow{2}{*}{$\begin{array}{c}\text { 2ndMorgage } \\
7\end{array}$} & \multirow{2}{*}{$\begin{array}{c}\text { AHP } \\
0.294\end{array}$} & \multirow{2}{*}{$\begin{array}{c}\text { Consistency check } \\
\text { Consistency OK }\end{array}$} \\
\hline Median_HH_Income_past12mos & 1 & 2 & 2 & 3 & 3 & 4 & 5 & & & & \\
\hline MedianHomeValue_dollars & $1 / 2$ & 1 & 1 & 2 & 2 & 3 & 4 & 5 & 6 & 0.168 & $3 \%$ \\
\hline MedianRent & $1 / 2$ & 1 & 1 & 2 & 2 & 3 & 4 & 5 & 6 & 0.168 & \\
\hline Median_year_structure_built & $1 / 3$ & $1 / 2$ & $1 / 2$ & 1 & 1 & 2 & 3 & 4 & 5 & 0.098 & \\
\hline UnitsinStructureCombined(1atta & $1 / 3$ & $1 / 2$ & $1 / 2$ & 1 & 1 & 2 & 3 & 4 & 5 & 0.098 & \\
\hline Tenure Total_OwnerOcc & $1 / 4$ & $1 / 3$ & $1 / 3$ & $1 / 2$ & $1 / 2$ & 1 & 2 & 3 & 4 & 0.064 & \\
\hline Estimate_HUs & $1 / 5$ & $1 / 4$ & $1 / 4$ & $1 / 3$ & $1 / 3$ & $1 / 2$ & 1 & 2 & 3 & 0.046 & \\
\hline Vacant Total & $1 / 6$ & $1 / 5$ & $1 / 5$ & $1 / 4$ & $1 / 4$ & $1 / 3$ & $1 / 2$ & 1 & 2 & 0.035 & \\
\hline \multirow[t]{7}{*}{ 2ndMorgage } & $1 / 7$ & $1 / 6$ & $1 / 6$ & $1 / 5$ & $1 / 5$ & $1 / 4$ & $1 / 3$ & $1 / 2$ & 1 & 0.028 & \\
\hline & HON/OI & \#DIV/O! & \#OAN/O! & \#OIV/O4 & \#DAV/OH & HOAv/O4 & \#DIV/OH & \#DIV/O! & HOIV/O4 & & \\
\hline & \#DIN/O! & \#DIV/O! & \#DIN/O! & \#DIV/OI & \#DIN/O! & \#ON/O! & \#OIV/O! & \#DIV/O! & \#DIV/Ol & & \\
\hline & \#DIV/O! & \#OAV/O! & \#DIV/0! & \#DIV/O! & \#DIN/O! & HOIV/O! & \#OIV/O! & \#DIV/O! & \#OIV/O! & & \\
\hline & Heivfor & \#DNF/ & HONYOH & \#DIN/OH & \#DN/OH & \#DEN/Ot & HON/Ot & HOVIOH & \#DIV/Ot & & \\
\hline & \#OW/OH & newpol & \#OIV/OI & \#avyout & Hew/ol & Hew/O! & \#avfor & \#01v/01. & \#avyou & & \\
\hline & \#DIV/0! & \#DIN/0! & \#DIN/O! & \#DIV/O! & \#DIV/O! & \#ON/O! & \#OIV/O! & \#DIV/O! & \#DIV/O! & & \\
\hline \multirow[t]{12}{*}{ Column totals } & 3.4262 & 5.9500 & 5.9500 & 10.2833 & 10.2833 & 16.0833 & 22.8333 & 30.5000 & 39.0000 & & \\
\hline & Cw (Normalised) & & & & & & & & & & \\
\hline & 0.291869354 & 0.336134454 & 0.336134454 & 0.291734198 & 0.291734198 & 0.248704663 & 0.218978102 & 0.196721311 & 0.179487179 & & \\
\hline & 0.145934677 & 0.168067227 & 0.168067227 & 0.194489465 & 0.194489465 & 0.186528497 & 0.175182482 & 0.163934426 & 0.153846154 & & \\
\hline & 0.145934677 & 0.168067227 & 0.168067227 & 0.194489465 & 0.194489465 & 0.186528497 & 0.175182482 & 0.163934426 & 0.153846154 & & \\
\hline & 0.097289785 & 0.084033613 & 0.084033613 & 0.097244733 & 0.097244733 & 0.124352332 & 0.131386861 & 0.131147541 & 0.128205128 & & \\
\hline & 0.097289785 & 0.084033613 & 0.084033613 & 0.097244733 & 0.097244733 & 0.124352332 & 0.131386861 & 0.131147541 & 0.128205128 & & \\
\hline & 0.072967338 & 0.056022409 & 0.056022409 & 0.048622366 & 0.048622366 & 0.062176166 & 0.087591241 & 0.098360656 & 0.102564103 & & \\
\hline & 0.058373871 & 0.042016807 & 0.042016807 & 0.032414911 & 0.032414911 & 0.031088083 & 0.04379562 & 0.06557377 & 0.076923077 & & \\
\hline & 0.048644892 & 0.033613445 & 0.033613445 & 0.024311183 & 0.024311183 & 0.020725389 & 0.02189781 & 0.032786885 & 0.051282051 & & \\
\hline & \multirow{2}{*}{\multicolumn{4}{|c|}{ Add_AddAItRep_AElect_ElectGen_EPlumbing_Plumb Raze }} & 0.019448947 & 0.015544041 & 0.01459854 & 0.016393443 & 0.025641026 & & \\
\hline & & & & & New Building & Demolition & Mechanical & \multicolumn{2}{|c|}{ NA.CertOccupanı Building } & AHP & Consistency check \\
\hline Add_AddAltRep_AltRep & 1 & 2 & 2 & 3 & 4 & 5 & 6 & 7 & 8 & 0.312 & Consistency OK \\
\hline Elect_ElectGen_ElectHeavyUp & $1 / 2$ & 1 & 1 & 2 & 3 & 4 & 5 & 6 & 7 & 0.178 & $4 \%$ \\
\hline Plumbing_PlumbingGas & $1 / 2$ & 1 & 1 & 2 & 3 & 4 & 5 & 6 & 7 & 0.178 & \\
\hline Raze & $1 / 3$ & $1 / 2$ & $1 / 2$ & 1 & 2 & 3 & 4 & 5 & 6 & 0.108 & \\
\hline $\begin{array}{l}\text { New Building } \\
\text { Demolition }\end{array}$ & $\begin{array}{l}1 / 4 \\
1 / 5\end{array}$ & $\begin{array}{r}1 / 3 \\
\boldsymbol{+}_{1 / 4}\end{array}$ & $\begin{array}{l}1 / 3 \\
1 / 4\end{array}$ & $\begin{array}{l}1 / 2 \\
1 / 3\end{array}$ & $\begin{array}{l}1 \\
1 / 2\end{array}$ & $\begin{array}{l}2 \\
1\end{array}$ & $\begin{array}{l}3 \\
2\end{array}$ & $\begin{array}{l}4 \\
3\end{array}$ & $\begin{array}{l}5 \\
4\end{array}$ & 0.073 & \\
\hline \begin{tabular}{|l|} 
Demolition \\
Mechanical \\
\end{tabular} & $\begin{array}{l}1 / 5 \\
1 / 6\end{array}$ & $1 / 5$ & $1 / 5$ & $1 / 4$ & $1 / 3$ & $1 / 2$ & 1 & 2 & $\begin{array}{l}4 \\
3\end{array}$ & 0.053 & \\
\hline NA.CertOccupancy & $1 / 7$ & $1 / 6$ & $1 / 6$ & $1 / 5$ & $1 / 4$ & $1 / 3$ & $1 / 2$ & 1 & 2 & 0.040 & \\
\hline \multirow[t]{6}{*}{ Building } & $1 / 8$ & $1 / 7$ & $1 / 7$ & $1 / 6$ & $1 / 5$ & $1 / 4$ & $1 / 3$ & $1 / 2$ & 1 & $\begin{array}{l}0.032 \\
0.026\end{array}$ & \\
\hline & \#DIV/0! & \#DIV/O! & HOIV/O! & HOIV/O! & HOIV/OI & \#DIV/O! & \#DIN/O! & \#DIV/O! & \#DIV/O! & & \\
\hline & \#DIV/OH & \#DIV/OI & HOWFOH & HOWV/O! & HOW/Ot & \#ON/O4 & \#DWF/04 & \#DIN/OH & \#DIV/O! & & \\
\hline & \#DIV/O! & \#DIV/O! & \#DEF/OH & HDIV/OH & HOIV/O! & \#DIN/0! & \#DIV/O! & \#DIV/O! & \#DIN/O! & & \\
\hline & $\begin{array}{l}\text { \#DIV/0! } \\
\text { \#DIV/O! }\end{array}$ & $\begin{array}{l}\text { \#DIV/O! } \\
\text { \#OIV/O! }\end{array}$ & $\begin{array}{l}\text { \#DIV/O! } \\
\text { HOIV/O! }\end{array}$ & $\begin{array}{l}\text { \#DIV/O! } \\
\text { \#DIV/O! }\end{array}$ & $\begin{array}{l}\text { \#DIV/O! } \\
\text { \#OIV/O! }\end{array}$ & $\begin{array}{l}\text { \#DIV/0! } \\
\text { \#DIV/O! }\end{array}$ & $\begin{array}{l}\text { \#DIV/O! } \\
\text { \#DIV/O! }\end{array}$ & $\begin{array}{l}\text { \#DIV/O! } \\
\text { \#PIV/O! }\end{array}$ & $\begin{array}{l}\text { \#PIV/O! } \\
\text { \#PIV/O! }\end{array}$ & & \\
\hline & \#OAN/O! & HOWV/O! & HOWF/O! & Hew/Ot & HOWV/O! & \#DAN/O! & HOW/O! & \#PIV/O! & \#DIN/O! & & \\
\hline \multirow{11}{*}{$\begin{array}{l}1 \\
2 \\
3 \\
4 \\
5 \\
6 \\
7 \\
8 \\
9\end{array}$} & 3.2179 & 5.5929 & 5.5929 & 9.4500 & 14.2833 & 20.0833 & 26.8333 & 34.5000 & 43.0000 & & \\
\hline & Cw (Normalised) & & & & & & & & & & \\
\hline & 0.310765816 & 0.357598978 & 0.357598978 & 0.317460317 & 0.280046674 & 0.248962656 & 0.223602484 & 0.202898551 & 0.186046512 & & \\
\hline & 0.155382908 & 0.178799489 & 0.178799489 & 0.211640212 & 0.210035006 & 0.199170124 & 0.186335404 & 0.173913043 & 0.162790698 & & \\
\hline & 0.155382908 & 0.178799489 & 0.178799489 & 0.211640212 & 0.210035006 & 0.199170124 & 0.186335404 & 0.173913043 & 0.162790698 & & \\
\hline & 0.103588605 & 0.089399745 & 0.089399745 & 0.105820106 & 0.140023337 & 0.149377593 & 0.149068323 & 0.144927536 & 0.139534884 & & \\
\hline & 0.077691454 & 0.05959983 & 0.05959983 & 0.052910053 & 0.070011669 & 0.099585062 & 0.111801242 & 0.115942029 & 0.11627907 & & \\
\hline & 0.062153163 & 0.044699872 & 0.044699872 & 0.035273369 & 0.035005834 & 0.049792531 & 0.074534161 & 0.086956522 & 0.093023256 & & \\
\hline & 0.051794303 & 0.035759898 & 0.035759898 & 0.026455026 & 0.023337223 & 0.024896266 & 0.037267081 & 0.057971014 & 0.069767442 & & \\
\hline & 0.044395117 & 0.029799915 & 0.029799915 & 0.021164021 & 0.017502917 & 0.01659751 & 0.01863354 & 0.028985507 & 0.046511628 & & \\
\hline & 0.038845727 & 0.025542784 & 0.025542784 & 0.017636684 & 0.014002334 & 0.012448133 & 0.01242236 & 0.014492754 & 0.023255814 & & \\
\hline
\end{tabular}




\section{Appendix B - Media Sources}

\section{Table A-1: A decomposition extraction assessment of media articles referencing gentrification in Washington D.C}

\begin{tabular}{|c|c|c|c|c|c|}
\hline ID & Source & $\begin{array}{l}\text { Publi } \\
\text { catio } \\
\text { n } \\
\text { Date }\end{array}$ & Author & Category & Title \\
\hline 1 & CNNMoney & $\begin{array}{l}9 / 25 / \\
2017\end{array}$ & Mat Egan & $\begin{array}{l}\text { General/B } \\
\text { anking and } \\
\text { Investment }\end{array}$ & $\begin{array}{l}\text { JPMorgan devotes } \$ 10 \text { million to fight poverty in } \\
\text { Washington D.C }\end{array}$ \\
\hline 2 & $\begin{array}{l}\text { The Washington } \\
\text { Post }\end{array}$ & $\begin{array}{l}2 / 23 / \\
2017\end{array}$ & Jean Folger & $\begin{array}{l}\text { General/B } \\
\text { anking and } \\
\text { Investment }\end{array}$ & 7 Gentrifying Neighborhoods In Washington, D.C. \\
\hline 3 & Governing.com & $\begin{array}{l}7 / 20 / \\
2017\end{array}$ & David Rusk & $\begin{array}{l}\text { News/Loc } \\
\text { al Web }\end{array}$ & Goodbye to Chocolate City \\
\hline 4 & NPR & $\begin{array}{l}9 / 14 / \\
2015\end{array}$ & $\begin{array}{l}\text { Michelle } \\
\text { Goldchain }\end{array}$ & General & Mapping Gentrification in Washington, D.C. \\
\hline 5 & $\begin{array}{l}\text { OZY (World Net } \\
\text { News) and JP } \\
\text { Morgan Chase }\end{array}$ & $\begin{array}{l}10 / 11 \\
/ 2017\end{array}$ & $\begin{array}{l}\text { Delia } \\
\text { Goncalves }\end{array}$ & $\begin{array}{l}\text { News/Loc } \\
\text { al Web }\end{array}$ & $\begin{array}{l}\text { Gentrification in DC raises property values, but does it } \\
\text { also push people out? } \\
\text { The unintended consequences of what some call this } \\
21 \text { st Century urban renewal. }\end{array}$ \\
\hline 6 & $\begin{array}{l}\text { WUSA Local DC } \\
\text { News }\end{array}$ & $\begin{array}{l}12 / 5 / \\
2017\end{array}$ & $\begin{array}{l}\text { Daniella } \\
\text { Zessoules }\end{array}$ & News & $\begin{array}{l}\text { Gentrification in Washington, D.C.: Not Just Historic } \\
\text { Height Limits and Hip Coffee Shops }\end{array}$ \\
\hline 7 & Investopedia & $\begin{array}{l}10 / 13 \\
/ 2017 \\
\end{array}$ & $\begin{array}{l}\text { Alex } \\
\text { Mooney }\end{array}$ & $\begin{array}{l}\text { News/Loc } \\
\text { al Web }\end{array}$ & Inequality Displaces Black DC Residents \\
\hline 8 & $\begin{array}{l}\text { WTOP Local DC } \\
\text { News }\end{array}$ & $\begin{array}{l}10 / 2 / \\
2017\end{array}$ & Steve Dubb & News & $\begin{array}{l}\text { DC Adopts Community Land Trust Approach to Avert } \\
\text { Further Gentrification }\end{array}$ \\
\hline 9 & AFRO & $\begin{array}{l}12 / 21 \\
/ 2017 \\
\end{array}$ & Alisha Butler & $\begin{array}{l}\text { News/Loc } \\
\text { al Web }\end{array}$ & $\begin{array}{l}\text { Gentrification can increase school diversity, a new } \\
\text { study of DC shows }\end{array}$ \\
\hline 10 & The Hoya & $\begin{array}{l}9 / 16 / \\
2015\end{array}$ & $\begin{array}{l}\text { Kojo } \\
\text { Nnamdi }\end{array}$ & $\begin{array}{l}\text { News/Loc } \\
\text { al Web }\end{array}$ & Gentrification's Latest Victim? D.C.'s Historic Murals \\
\hline 11 & Therealstreetz & $\begin{array}{l}4 / 29 / \\
2013\end{array}$ & $\begin{array}{l}\text { Matthew } \\
\text { Yglesias }\end{array}$ & $\begin{array}{l}\text { News/Loc } \\
\text { al Web }\end{array}$ & The Perverse Politics of Gentrification \\
\hline 12 & Nonprofit Quarterly & $\begin{array}{l}12 / 6 / \\
2016\end{array}$ & $\begin{array}{l}\text { Dyana } \\
\text { Forester }\end{array}$ & News & Washington, D.C.: A Tale Of Two Cities \\
\hline 13 & The Atlantic & $\begin{array}{r}6 / 8 / 2 \\
016\end{array}$ & $\begin{array}{l}\text { Pamela } \\
\text { Boyce } \\
\text { Simms }\end{array}$ & $\begin{array}{l}\text { News/Loc } \\
\text { al }\end{array}$ & $\begin{array}{l}\text { At the Nexus of Gentrification and Environmentalism } \\
\text { How Groundwork Anacostia River DC is Shaping } \\
\text { Their Own Future }\end{array}$ \\
\hline 14 & $\begin{array}{l}\text { Greater Greater } \\
\text { Washington }\end{array}$ & $\begin{array}{r}7 / 7 / 2 \\
016 \\
\end{array}$ & $\begin{array}{l}\text { Lisa } \\
\text { Sturtevant }\end{array}$ & News & Can We Predict Gentrification? \\
\hline 15 & $\begin{array}{l}\text { Greater Greater } \\
\text { Washington }\end{array}$ & $\begin{array}{l}9 / 14 / \\
2015\end{array}$ & $\begin{array}{l}\text { Kate } \\
\text { Rabinowitz }\end{array}$ & Data & DC Gentrification by the Numbers \\
\hline 16 & Realtor.com & $\begin{array}{l}1 / 23 / \\
2017\end{array}$ & Yuqing Pan & $\begin{array}{l}\text { News/Nati } \\
\text { onal }\end{array}$ & $\begin{array}{l}\text { The U.S. Cities That Are Gentrifying the Fastest- } \\
\text { You'll Never Guess No. } 1\end{array}$ \\
\hline 17 & The Daily Beast & $\begin{array}{l}12 / 11 \\
/ 2015 \\
\end{array}$ & David Alpert & $\begin{array}{l}\text { News/Loc } \\
\text { al Web }\end{array}$ & $\begin{array}{l}\text { House prices are skyrocketing in central DC } \\
\text { neighborhoods, but not in outlying ones }\end{array}$ \\
\hline 18 & $\begin{array}{l}\text { FOX5 Local DC } \\
\text { News }\end{array}$ & $\begin{array}{r}9 / 2 / 2 \\
016\end{array}$ & $\begin{array}{l}\text { Uzodinma } \\
\text { Iweala }\end{array}$ & News & $\begin{array}{l}\text { The gentrification of Washington DC: how my city } \\
\text { changed its colours }\end{array}$ \\
\hline
\end{tabular}




\begin{tabular}{|c|c|c|c|c|c|}
\hline 19 & $\begin{array}{l}\text { NPR (Kojo Nnamdi } \\
\text { Show) }\end{array}$ & $\begin{array}{l}11 / 2 / \\
2017\end{array}$ & $\begin{array}{l}\text { Laura } \\
\text { Elizabeth }\end{array}$ & $\begin{array}{l}\text { General/B } \\
\text { anking and } \\
\text { Investment }\end{array}$ & $\begin{array}{l}\text { Washington, D.C., Is Taking a Gamble to Fight } \\
\text { Gentrification }\end{array}$ \\
\hline 20 & Marketplace.org & $\begin{array}{l}4 / 20 / \\
2015\end{array}$ & Sean Nevins & News & $\begin{array}{l}\text { Beyond Gentrification: Hundreds Of DC Residents } \\
\text { Being Forced From Their Homes }\end{array}$ \\
\hline 21 & The Root & $\begin{array}{r}7 / 8 / 2 \\
015\end{array}$ & Perry Stein & $\begin{array}{l}\text { News/Loc } \\
\text { al }\end{array}$ & $\begin{array}{l}\text { A D.C. resident hopes these yard signs can save his } \\
\text { neighborhood from gentrifiers }\end{array}$ \\
\hline 22 & Vice News & $\begin{array}{l}8 / 11 / \\
2014\end{array}$ & $\begin{array}{l}\text { Vann R. } \\
\text { Newkirk II }\end{array}$ & News & $\begin{array}{l}\text { Irrigating the (Food) Desert: A Tale of Gentrification } \\
\text { in D.C }\end{array}$ \\
\hline 23 & Slate & $\begin{array}{l}5 / 11 / \\
2013\end{array}$ & Dan Mizrahi & $\begin{array}{l}\text { News/Loc } \\
\text { al Web }\end{array}$ & $\begin{array}{l}\text { The Target Effect, or, How Big Box Is Bringing } \\
\text { Washington D.C. Together; Dan Mizrahi reports on } \\
\text { how Target became the symbol of a changning } \\
\text { neighborhood }\end{array}$ \\
\hline 24 & CNN Money & $\begin{array}{l}9 / 14 / \\
2012 \\
\end{array}$ & $\begin{array}{l}\text { Martin } \\
\text { DiCaro }\end{array}$ & News & $\begin{array}{l}\text { D.C.'s Ward } 7 \text { Prepares For New Growth, New } \\
\text { Residents }\end{array}$ \\
\hline 25 & DC Policy Center & $\begin{array}{l}6 / 12 / \\
2006\end{array}$ & $\begin{array}{l}\text { Lyndsay } \\
\text { Layton }\end{array}$ & $\begin{array}{l}\text { General/B } \\
\text { anking and } \\
\text { Investment }\end{array}$ & $\begin{array}{l}\text { Breathing New Rhythm Into Tired Streets; Yoga } \\
\text { Studios Signal D.C. Gentrification }\end{array}$ \\
\hline 26 & $\begin{array}{l}\text { Captal News } \\
\text { Service Maryland }\end{array}$ & $\begin{array}{r}2 / 5 / 2 \\
018\end{array}$ & $\begin{array}{l}\text { Jeff } \\
\text { Clabaugh }\end{array}$ & $\begin{array}{l}\text { News/Loc } \\
\text { al TV }\end{array}$ & 2 DC ZIP codes among nation's 'most gentrified' \\
\hline 27 & Gawker & $\begin{array}{l}12 / 26 \\
/ 2017\end{array}$ & $\begin{array}{l}\text { Andrew } \\
\text { Small }\end{array}$ & $\begin{array}{l}\text { News/Loc } \\
\text { al Web }\end{array}$ & Bikes and Cycling \\
\hline 28 & City Lab & $\begin{array}{l}7 / 18 / \\
2017\end{array}$ & $\begin{array}{l}\text { Adam } \\
\text { Allington }\end{array}$ & $\begin{array}{l}\text { News/Loc } \\
\text { al Web }\end{array}$ & NOMA BID/Eckington \\
\hline 29 & Next City & $\begin{array}{r}3 / 9 / 2 \\
017\end{array}$ & Scott Rodd & $\begin{array}{l}\text { News/Loc } \\
\text { al Web }\end{array}$ & $\begin{array}{l}\text { Gentrified: A tale of two neighborhoods in } \\
\text { Washington, D.C. }\end{array}$ \\
\hline 30 & $\begin{array}{l}\text { Lakritz Adler Real } \\
\text { Estate Dev }\end{array}$ & $\begin{array}{l}3 / 15 / \\
2017\end{array}$ & Scott Rodd & $\begin{array}{l}\text { News/Loc } \\
\text { al Web }\end{array}$ & $\begin{array}{l}\text { The uncertain future of low-income housing in the } \\
\text { heart of D.C. }\end{array}$ \\
\hline 31 & $\begin{array}{l}\text { Medium Corp } \\
\text { (good quotes) }\end{array}$ & $\begin{array}{l}9 / 10 / \\
2012 \\
\end{array}$ & $\begin{array}{l}\text { Martin } \\
\text { DiCaro }\end{array}$ & $\begin{array}{l}\text { News/Tran } \\
\text { sport }\end{array}$ & $\begin{array}{l}\text { Special Report: How Transit Is Shaping the } \\
\text { Gentrification of D.C., Part } 1 \text {. }\end{array}$ \\
\hline 32 & Medium Corp & $\begin{array}{l}12 / 23 \\
/ 2014\end{array}$ & $\begin{array}{l}\text { Janelle } \\
\text { Harris }\end{array}$ & $\begin{array}{l}\text { News/Loc } \\
\text { al Web }\end{array}$ & 11 Signs Your Hood Is Being Gentrified \\
\hline 33 & Huffington Post & $\begin{array}{l}6 / 12 / \\
2017\end{array}$ & Derek Hyra & $\begin{array}{l}\text { News/Loc } \\
\text { al Web }\end{array}$ & $\begin{array}{l}\text { "Selling a Black D.C. Neighborhood to White } \\
\text { Millennials" washingtondc real estate branding white } \\
\text { millennials }\end{array}$ \\
\hline 34 & $\begin{array}{l}\text { HAND (The } \\
\text { Housing } \\
\text { Association of } \\
\text { Nonprofit } \\
\text { Developers) }\end{array}$ & $\begin{array}{r}5 / 3 / 2 \\
017 \\
\end{array}$ & $\begin{array}{l}\text { Robert } \\
\text { McCartney }\end{array}$ & $\begin{array}{l}\text { News/Loc } \\
\text { al Paper }\end{array}$ & $\begin{array}{l}\text { 'Black branding' - how a D.C. neighborhood was } \\
\text { marketed to white millennials }\end{array}$ \\
\hline 35 & Data Lens DC & $\begin{array}{l}1 / 16 / \\
2017\end{array}$ & $\begin{array}{l}\text { Sam } \\
\text { Gringlas } \\
\text { (Author)/Raq } \\
\text { uel Zaldivar }\end{array}$ & $\begin{array}{l}\text { News/Nati } \\
\text { onal }\end{array}$ & $\begin{array}{l}\text { Old Confronts New In A Gentrifying D.C. } \\
\text { Neighborhood }\end{array}$ \\
\hline 36 & WNYC & $\begin{array}{l}8 / 10 / \\
2012\end{array}$ & $\begin{array}{l}\text { Garance } \\
\text { Franke-Ruta }\end{array}$ & News & $\begin{array}{l}\text { The Politics of the Urban Comeback: Gentrification } \\
\text { and Culture in D.C. }\end{array}$ \\
\hline 37 & WAMU & $\begin{array}{l}12 / 9 / \\
2016\end{array}$ & $\begin{array}{l}\text { Camille } \\
\text { Chrysostom }\end{array}$ & $\begin{array}{l}\text { News/Loc } \\
\text { al Web }\end{array}$ & $\begin{array}{l}\text { Gentrification spreading from Washington, D.C. to } \\
\text { Prince George's County }\end{array}$ \\
\hline 38 & MintPress News & $\begin{array}{l}3 / 28 / \\
2016\end{array}$ & $\begin{array}{l}\text { Briana } \\
\text { Younger }\end{array}$ & News & $\begin{array}{l}\text { How Gentrification and Geography Influence DC Hip- } \\
\text { Hop } \\
\text { The sound of DC is changing, and hip-hop, long } \\
\text { overshadowed by go-go, is becoming more prominent. }\end{array}$ \\
\hline
\end{tabular}




\section{Bibliography for Table A-2}

Allington, A. (2017). NOMA BID/Eckington. City Lab. https://www.nomabid.org/theneighborhood. Retrieved November 10, 2018

Alpert, D. (2015). House prices are skyrocketing in central DC neighborhoods, but not in outlying ones. The Daily Beast. https://ggwash.org/view/40203/house-prices-areskyrocketing-in-central-dc-neighborhoods-but-not-in-outlying-ones. Retrieved November 2,2018

Boyce-Simms, P. (2016). At the Nexus of Gentrification and Environmentalism: How Groundwork Anacostia River DC is Shaping Their Own Future. The Atlantic. http://www.geo.coop/story/nexus-gentrification-and-environmentalism. Retrieved October 11, 2018

Butler, A. (2017). Gentrification can increase school diversity, a new study of DC shows. AFRO. https://ggwash.org/view/65994/gentrification-can-increase-school-diversity-a-new-studyof-dc-schools-shows. Retrieved October 11, 2018

Chrysostom, C. (2016). Gentrification spreading from Washington, D.C. to Prince George's County. WAMU. http://cnsmaryland.org/2016/12/09/gentrification-spreading-fromwashington-d-c-to-prince-georges-county/. Retrieved November 10, 2018

Clabaugh, J. (2018). 2 DC ZIP codes among nation's 'most gentrified'. Captal News Service Maryland. https://wtop.com/real-estate/2018/03/most-gentrified-zip-codes-dc/. Retrieved November 2, 2018

DiCaro, M. (2012). D.C.'s Ward 7 Prepares For New Growth, New Residents. CNN Money. https://wamu.org/story/12/09/14/from_a_to_b_des_ward_7_prepares_for_new_growth_n ew_residents/. Retrieved November 2, 2018

DiCaro, M. (2012). Special Report: How Transit Is Shaping the Gentrification of D.C., Part 1.. Medium Corp (good quotes). http://www.wnyc.org/story/284287-gentrification-andtransportation-in-dc-part-1/. Retrieved November 10, 2018

Dubb, S. (2017). DC Adopts Community Land Trust Approach to Avert Further Gentrification. WTOP Local DC News. https://nonprofitquarterly.org/2017/10/02/dc-adopts-communityland-trust-approach-avert-gentrification/. Retrieved October 11, 2018 
Egan, M. (2017). JPMorgan devotes $\$ 10$ million to fight poverty in Washington D.C. CNNMoney. http://money.cnn.com/2017/09/25/investing/washington-dc-jpmorgandimon-inequality/index.html. Retrieved July 14, 2018

Elizabeth, L. (2017). Washington, D.C., Is Taking a Gamble to Fight Gentrification. NPR (Kojo Nnamdi Show). https://www.ozy.com/acumen/washington-dc-is-taking-a-gamble-tofight-gentrification/81828. Retrieved November 2, 2018

Folger, J. (2017). 7 Gentrifying Neighborhoods In Washington, D.C.. The Washington Post. https:/www.investopedia.com/articles/investing/022317/7-gentrifying-neighborhoodswashington-dc.asp. Retrieved July 15, 2018

Forester, D. (2016). Washington, D.C.: A Tale Of Two Cities. Nonprofit Quarterly. https://www.huffingtonpost.com/entry/dc-a-tale-of-twocities_us_5846e6eee4b016eb81d823e5. Retrieved October 11, 2018

Franke-Ruta, G. (2012). The Politics of the Urban Comeback: Gentrification and Culture in D.C. WNYC. https://www.theatlantic.com/politics/archive/2012/08/the-politics-of-the-urbancomeback-gentrification-and-culture-in-dc/260741/. Retrieved November 10, 2018

Goldchain, M. (2015). Mapping Gentrification in Washington, D.C. NPR. https://dc.curbed.com/washington-dc-gentrification. Retrieved August 25, 2018

Goncalves, D. (2017). Gentrification in DC raises property values, but does it also push people out? The unintended consequences of what some call this 21st Century urban renewal. . OZY (World Net News) and JP Morgan Chase. http://www.wusa9.com/article/news/local/dc/gentrification-in-dc-raises-property-valuesbut-does-it-also-push-people-out/65-482281216. Retrieved August 25, 2018"

Gringlas \& Zaldivar, S. (2017). Old Confronts New In A Gentrifying D.C. Neighborhood. Data Lens DC. https://www.npr.org/2017/01/16/505606317/d-c-s-gentrifying-neighborhoodsa-careful-mix-of-newcomers-and-old-timers.Retrieved November 10, 2018

Harris, J. (2014). 11 Signs Your Hood Is Being Gentrified. Medium Corp. https://www.theroot.com/11-signs-your-hood-is-being-gentrified-1790878177. Retrieved November 10, 2018

Hyra, D. (2017). "Selling a Black D.C. Neighborhood to White Millennials" Washington DC real estate branding white millennials. Huffington Post.https://nextcity.org/features/view/washington-dc-real-estate-branding-whitemillennials. Retrieved November 10, 2018 
Iweala, U. (2016). The gentrification of Washington DC: how my city changed its colors. FOX5 Local DC News. https://www.theguardian.com/cities/2016/sep/12/gentrificationwashington-dc-how-my-city-changed-colours. Retrieved November 2, 2018

Layton, L. (2006). Breathing New Rhythm Into Tired Streets; Yoga Studios Signal D.C. Gentrification. DC Policy Center. http://www.lakritzadler.com/02-Breathing-NewRhythm-WashingtonPost-June2006.php. Retrieved November 2, 2018

McCartney, R. (2017). 'Black branding' - how a D.C. neighborhood was marketed to white millennials. HAND (The Housing Association of Nonprofit Developers). https://www.washingtonpost.com/local/black-branding--how-a-dc-neighborhood-wasmarketed-to-white-millenials/2017/05/02/68b0ae06-2f47-11e7-953400e4656c22aa_story.html?utm_term=.abdeb8e36845. Retrieved November 10, 2018

Mizrahi, D. (2013). The Target Effect or How Big Box Is Bringing Washington D.C. Together; Dan Mizrahi reports on how Target became the symbol of a changing neighborhood. Slate. https://www.thedailybeast.com/the-target-effect-or-how-big-box-is-bringingwashington-dc-together. Retrieved November 2, 2018"

Mooney, A. (2017). Inequality Displaces Black DC Residents . Investopedia. http://www.thehoya.com/inequality-displaces-black-dc-residents/. Retrieved October 11, 2018

Nevins, S. (2015). Beyond Gentrification: Hundreds Of DC Residents Being Forced From Their Homes. Marketplace.org. http://www.mintpressnews.com/beyond-gentrificationhundreds-of-dc-residents-being-forced-from-their-homes/204543/. Retrieved November 2,2018

Nnamdi, K. (2015). Gentrification's Latest Victim? D.C.'s Historic Murals. The Hoya. https://thekojonnamdishow.org/shows/2015-09-16/gentrifications-latest-victim-d-c-shistoric-murals. Retrieved October 11, 2018

Pan, Y. (2017). The U.S. Cities That Are Gentrifying the Fastest-You'll Never Guess No. 1. Realtor.com. https://www.realtor.com/news/trends/10-surprising-cities-that-aregentrifying-the-fastest/. Retrieved November 2, 2018

R. Newkirk, V. (2014). Irrigating the (Food) Desert: A Tale of Gentrification in D.C. Vice News. http://gawker.com/irrigating-the-food-desert-a-tale-of-gentrification-1617679708.

Retrieved November 2, 2018

Rabinowitz, K. (2015). DC Gentrification by the Numbers. Greater Greater Washington. http://www.datalensdc.com/gentrification-by-numbers.html.. Retrieved November 2, 2018 
Rodd, S. (2017). Gentrified: A tale of two neighborhoods in Washington, D.C.. Next City. https://medium.com/@ScottCRodd/gentrified-a-tale-of-two-neighborhoods-inwashington-d-c-c828b8f7a357. Retrieved November 10, 2018

Rodd, S. (2017). The uncertain future of low-income housing in the heart of D.C.. Lakritz Adler Real Estate Dev. https://medium.com/@ScottCRodd/the-uncertain-future-of-low-incomehousing-in-the-heart-of-d-c-8alb668fa0d2. Retrieved November 10, 2018

Rusk, D. (2017). Goodbye to Chocolate City. Governing.com. https://www.dcpolicycenter.org/publications/goodbye-to-chocolate-city/. Retrieved July 15,2018

Small, A. (2017). Bikes and Cycling. Gawker. https://www.citylab.com/transportation/2017/12/how-washington-dc-built-a-bikeboom/548903/. Retrieved November 10, 2018

Stein, P. (2015). A D.C. resident hopes these yard signs can save his neighborhood from gentrifiers. The Root. https://www.washingtonpost.com/local/a-longtime-dc-residenthopes-these-yard-signs-can-save-his-neighborhood-fromgentrifiers/2015/07/08/cf1a1776-259f-11e5-b72c-2b7d516ele0e_story.html. Retrieved November 2, 2018

Sturtevant, L. (2016). Can We Predict Gentrification?. Greater Greater Washington. https://www.handhousing.org/can-we-predict-gentrification/. Retrieved October 11, 2018

Wright, J. (2018). D.C.'s Deanwood is Slowly Gentrifying. The Washington Post. http://www.afro.com/d-c-s-deanwood-slowly-gentrifying/. Retrieved November 10, 2018

Yglesias, M. (2013). The Perverse Politics of Gentrification. Therealstreetz. http://www.slate.com/blogs/moneybox/2013/04/29/trees rent and inequality the perver se_politics_of_gentrification.html. Retrieved October 11, 2018

Younger, B. (2016). How Gentrification and Geography Influence DC Hip-Hop: The sound of DC is changing, and hip-hop, long overshadowed by go-go, is becoming more prominent.. MintPress News. https://www.vice.com/en_us/article/zng9p5/capitol-hiphop-v23n1. Retrieved November 10, 2018"

Zessoules, D. (2017). Gentrification in Washington, D.C.: Not Just Historic Height Limits and Hip Coffee Shops . WUSA Local DC News. http://cepr.net/blogs/ceprblog/gentrification-in-washington-d-c-not-just-historic-height-limits-and-hip-coffeeshops. Retrieved August 25, 2018 


\section{Appendix C - References}

Aike, A. S., Ate, P., Bu-Sung, L., \& Markus Schläpfer. (2018). The canary in the city: indicator groups as predictors of local rent increases. Epj Data Science, 7(1), 1-15. https://doi.org/10.1140/epjds/s13688-018-0151-y

Anselin, L. \& GeoDa. (2020). Local Spatial Autocorrelation. Retrieved October 11, 2020, from https://Geodacenter.Github.Io/Workbook/5a global auto/Lab5a.Html. https://geodacenter.github.io/workbook/6b local_adv/lab6b.html

Atkinson, Rowland. (2000). Measuring gentrification and displacement in greater London. Urban Studies 37 (1): 149-65.

Barton, M. S., Valasik, M. A., Brault, E., \& Tita, G. (2020). “Gentefication” in the barrio: examining the relationship between gentrification and homicide in east Los Angeles. Crime and Delinquency, 66(13-14), 1888-1913. https://doi.org/10.1177/0011128719860835

Braswell, T. H. (2018). Fresh food, new faces: community gardening as ecological gentrification in St. Louis, Missouri. Agriculture and Human Values, 1-14, 1. https://doi.org/10.1007/s10460-018-9875-3

Christafore, D., \& Leguizamon, S. (2019). Neighborhood inequality spillover effects of gentrification. Papers in Regional Science, 98(3), 1469-1484. https://doi.org/10.1111/pirs.12405

Department of Consumer and Regulatory Affairs. (2011-2017). Permit Records (Washington D.C Permit Records) [Database Portal for the Washington D.C Building Permit Records]. https://dcra.dc.gov/page/permit-records

ESRI. The American Community Survey. (2017), retrieved August 22, 2019 from http://downloads.esri.com/esri content_doc/dbl/us/J10020_American_Community_Surv ey_2017.pdf

ESRI. How Geographically Weighted Regression (GWR) works-ArcGIS Pro | Documentation. (2020). Pro.Arcgis.Com. Retrieved October 14, 2020, from https://pro.arcgis.com/en/proapp/tool-reference/spatial-statistics/how-geographicallyweightedregression-works.htm

Fouch, Nakisha Tena. (2012). Planning for gentrification: A geographic analysis of gentrification susceptibility in the city of Asheville, N.C. ProQuest, UMI Dissertations Publishing.

Franke-Ruta,Garance. (2012).Facts and Fictions of D.C.'s Gentrification. Retrieved from http://www.theatlanticcities.com/politics/ 
Gafvert, Rebecca C. (2011). Mapping the Path of Gentrification: An Analysis of Gentrification Susceptibility in Cincinnati, Ohio. ProQuest, UMI Dissertations Publishing.

Gambrill, Kevin M. (2007). Neighborhood change and gentrification: Identification and analysis of small areas within Baltimore city, Maryland. ProQuest, UMI Dissertations Publishing.

Gibson, Timothy A. (2005). Selling city living: Urban branding campaigns, class power and the civic good. International Journal of Cultural Studies 8(3): 259-280.

Glaeser, E. L., Kim, H., \& Luca, M. (2018). Measuring gentrification: using yelp data to quantify neighborhood change. National Bureau of Economic Research Working Paper Series, 24952.

Glass, R. (1961). London's newcomers: the west indian migrants (Ser. Centre for urban studies, university college, London. report, no. 1. Harvard University Press.

Government of the District of Columbia. (2020). Open Data DC [Neighborhood Clusters]. DCGIS Open Data: Planning, Land-use and Zoning. https://opendata.dc.gov/search?q=neighborhood-clusters

Government of the District of Columbia. (2020). Open Data DC [DC Boundary]. DCGIS Open Data: Planning, Land-use and Zoning. https://opendata.dc.gov/datasets/washingtondc-boundary

Greater Capital Area Association of Realtors (GCAAR). (2019). November 2019 Washington, DC Market Trends Report Median sales price highest November level in the past 10 years. Retrieved from https:/gcaar.com/docs/default-source/dc-marketreports/gcaar_jan2016_dchousingmarketupdatefinal(3).pdf?sfvrsn=2https://gcaar.com/do cs/default-source/dc-market-reports/gcaar-dc-housing-market-update---november2019 _final.pdf? sfvrsn=ba0bdb93_2

Green, R. D., Mulusa, J. K., Byers, A. A., \& Parmer, C. (2017). The indirect displacement hypothesis: a case study in Washington, D.C. The Review of Black Political Economy, 44(1-2), 1-22. https://doi.org/10.1007/s12114-016-9242-9

Hartog, Rudolf. (1999). Growth without limits: Some case studies of 20th-century urbanization. International Planning Studies 4 (1): 95-130.

Heidkamp, Christian Patrick, and Susan Lucas. (2006). Finding the gentrification frontier using census data: The case of Portland, Maine. Urban Geography 27 (2): 101-25

Ilic, L., Sawada, M., \& Zarzelli, A. (2019). Deep mapping gentrification in a large canadian city using deep learning and google street view. Plos One, 14(3), 0212814. https://doi.org/10.1371/journal.pone.0212814 
Jiang, N., Pacheco, G., \& Dasgupta, K. (2019). Understanding the transient population: insights from linked administrative data. Journal of Population Research, 36(2), 111-136. https://doi.org/10.1007/s12546-019-09223-y

Kennedy, Maureen, and Paul Leonard. (2001). Dealing with neighborhood change: A primer on gentrification and policy choices. A Discussion Paper Prepared for The Brookings Institution Center on Urban and Metropolitan Policy. www.brookings.edu/urban and PolicyLink www.policylink.org. 1-70.

Krausmann, Fridolin, Simone Gingrich, Nina Eisenmenger, Karl-Heinz Erb, Helmut Haberl, and Marina Fischer-Kowalski. (2009). Growth in global materials use, GDP and population during the 20th century. Ecological Economics 68 (10): 2696-705.

Leonnig , Carol D. (2004). Tenants' suit accuses D.C. of prejudice in evictions; gentrification caused ouster, Hispanics say: FINAL edition. The Washington Post 2004.

Ley, David. 2003. Artists, Aestheticisation and The Field of Gentrification. Urban Studies 40(12): 2527-2544.

Ley, David, and Sin Yih Teo. (2014). Gentrification in Hong Kong? Epistemology vs. ontology. International Journal of Urban and Regional Research 38 (4): 1286-303.

Levy, Laura. (2009). Mapping gentrification in Pilsen: Community Empowerment through GIS Technology. Creating Knowledge: The LA\&S Student Research Journal 2 : 36-39.

Maciag, M. (2015). Washington, D.C., Gentrification Maps and Data. Governing. retrieved August 28, 2016 from https://www.governing.com/gov-data/washington-dcgentrification-maps-demographic-data.html

Maciag, Mike. (2015). “Gentrification in America Report.” Governing.Com, Governing, retrieved August 28, 2016 from $\underline{w w w}$.governing.com/gov-data/census/gentrification-incities-governing-report.html.

Mann, B., Bennett, H., \& Rogers, A. (2020). Gentrification, charter schools, and enrollment patterns in Washington, dc: shared growth or new forms of educational inequality? Peabody Journal of Education, 95(3), 211-228. https://doi.org/10.1080/0161956X.2020.1776070

Maantay, J. A., \& Maroko, A. R. (2018). Brownfields to greenfields: environmental justice versus environmental gentrification. International Journal of Environmental Research and Public Health, 15(10). https://doi.org/10.3390/ijerph15102233

Murphy, Caryle. 2004. Parents protest plan to sell youth club; Columbia Heights site would be used for condos with recreation facility: FINAL edition. The Washington Post 2004. 
Naik, N., Philipoom, J., Raskar, R., Hidalgo, C., \& 2014 IEEE Conference on Computer Vision and Pattern Recognition Workshops, CVPRW 201420140623 - 201406 28. (2014). Streetscore-predicting the perceived safety of one million streetscapes. Ieee Computer Society Conference on Computer Vision and Pattern Recognition Workshops, 2014september(September), 793-799. https://doi.org/10.1109/CVPRW.2014.121

Nesbitt, Ashon. (2005). A Model of Gentrification: Monitoring community change in selected neighborhoods of St. Petersburg, Florida using the analytic hierarchy process. ProQuest, UMI Dissertations Publishing.

O’Sullivan, Arthur. (2005). Gentrification and crime. Journal of Urban Economics 57 (1): 73-85.

Papachristos, Andrew V., Chris M. Smith, Mary L. Scherer, and Melissa A. Fugiero. (2011). More coffee, less crime? The relationship between gentrification and neighborhood crime rates in chicago, 1991 to 2005. City \& Community 10 (3): 215-40.

Reades, J., De Souza, J., \& Hubbard, P. (2019). Understanding urban gentrification through machine learning. Urban Studies, 56(5), 922-942. https://doi.org/10.1177/0042098018789054

Reed, J.(2012, ). Disappearing Act: Affordable Housing in DC is Vanishing Amid Sharply Rising Housing Costs,. D.C Fiscal Policy Institute. https://www.Dcfpi.Org/WpContent/Uploads/2012/05/5-7-12-Housing-and-Income-Trends-FINAL.Pd

Rose, Karen. 2002. Combating Gentrification through Equitable Development. Race, Poverty \& the Environment Fixin' to Stay: Anti-Displacement Policy Options \& Community Response, 9(1): 5-8.

Rosenthal, Stuart S., and Jan K. Brueckner. (2009). Gentrification and neighborhood housing cycles: Will america's future downtowns be rich? The Review of Economics and Statistics 91 (4): 725-43.

Saaty, R. W. (1987). The analytic hierarchy process - what it is and how it is used. Mathematical Modelling, 9(3), 161-176. https://doi.org/10.1016/0270-0255(87)90473-8

Saaty, T. L. (2013). The modern science of multicriteria decision making and its practical applications: the ahp/anp approach. Operations Research, 61(5), 1101-1118. https://doi.org/10.1287/opre.2013.1197

Schaffer, Richard, and Neil Smith. 1986. The gentrification of Harlem? Annals of the Association of American Geographers 76 (3): 347-65 
SCB Associates (2016). AHP Template SCBUK. SCB Associates Ltd. https://www.scbuk.com/ahp.html. Retrieved 4/20/2019

Scott, Derrick A. (2013). A case study of Anacostia: The role of housing vouchers on the local housing market. ProQuest, UMI Dissertations Publishing.

Shinault, C. M., \& Seltzer, R. (2019). Whose turf, whose town? race, status, and attitudes of washington dc residents toward gentrification. Journal of African American Studies, 23(1-2), 72-91. https://doi.org/10.1007/s12111-019-09427-9

Smith, Neil, and Peter Williams. (2007). Gentrification of the city. New York: Routledge.

Sommer, Will. (2012). “It's Been Invaded”: Newcomers and Native Washingtonians Clash at Gentrification Panel. Retrieved from http://www. Washingtoncitypaper.com/blogs/citydesk

Sternlieb, George and James Hughes. (1979). The Uncertain Future of Rental Housing. Policy Studies Journal 8 (2): 248-56

U.S. Census Bureau (2014). Washington D.C Block Groups selected demographic and housing characteristics Block Groups, 2009-2013 American Community Survey 5-year estimates. Retrieved from http://factfinder2.census.gov/faces/tableservices/jsf/pages/productview.xhtml?pid=ACS 13 5YR_DP04.

U.S. Census Bureau (2018). Washington D.C Block Groups selected demographic and housing characteristics, 2013-2017 American Community Survey 5-year estimates. Retrieved fromhttp://factfinder2.census.gov/faces/tableservices/jsf/pages/productview.xhtml?pid=A CS 17 5YR DP04.

U.S Census Bureau (2018). Understanding and Using American Community Survey Data Handbook. Retrieved from htps://www.census.gov/content/dam/Census/library/publications/2018/acs/acs_general_h andbook_2018.pdf

US Bureau of Labor Statistics. (2019). CPI Inflation Calculator. https://www.bls.gov/data/inflation_calculator.htm

U.S Census Bureau. (2020). American Community Survey: Sample Size. U.S Census Bureau American Community Survey. https://www.census.gov/acs/www/methodology/samplesize-and-data-quality/sample-size/index.php

US Census Bureau. (2020). American FactFinder is retiring March 31. The United States Census Bureau. https://www.census.gov/newsroom/press-releases/2020/americanfactfinder-retiring.html 
Wiener, Aaron. (2013). Are there any neighborhoods in D.C. that aren't currently being gentrified? Washington City Paper 2013.

Welch, Nicolas. (2013). City for all? A geospatial approach to equity, sustainability, and gentrification in Seattle, Washington. ProQuest, UMI Dissertations Publishing.

Wilgoren, Debbi and Jacqueline L. Salmon. (2004a). Columbia heights fears condo plan elbows out kids; boys \& girls club, developer dealing: FINAL edition. The Washington Post 2004.

Wilgoren, Debband Jacqueline L. Salmon. (2004b). In NW, condos vs. clubhouse; Columbia heights parents fear development will elbow out children: FINAL edition. The Washington Post 2004.

Wogan, J. B. (2015). Low-income residents more likely to leave D.C. Urban Governing. https://www.governing.com/topics/urban/gov-low-income-residents-districtcolumbia.html. Accessed 11 Mar 2019.

Wyly, Elvin K., and Daniel J. Hammel. (1998). Modeling the context and contingency of gentrification. Journal of Urban Affairs 20 (3): 303-26.

Wyly, Elvin K., and Daniel J. Hammel. (1999). Islands of Decay in Seas of Renewal: Housing Policy and the Resurgence of Gentrification, Housing Policy Debate, 10 (4): 711-771.

Zuk, M., Chapple, K., Gorska, K., Loukaitou-Sidaris, A., Ong, P., \& Thomas, T. (2015).

Gentrification, Displacement and the Role of Public Investment: A Literature Review. http://Iurd.Berkeley.Edu/Uploads/Displacement_Lit_Review_Final.Pdf. 